University of Michigan Law School

University of Michigan Law School Scholarship Repository

1943

\title{
The Prevention of Repeated Crime
}

John B. Waite

University of Michigan Law School

Follow this and additional works at: https://repository.law.umich.edu/michigan_legal_studies

Part of the Criminal Law Commons, and the Law Enforcement and Corrections Commons

\section{Recommended Citation}

Waite, John B. The Prevention of Repeated Crime. Hessel E. Yntema, editor. Michigan Legal Studies. Ann Arbor: University of Michigan Press, 1943.

This Book is brought to you for free and open access by the Law School History and Publications at University of Michigan Law School Scholarship Repository. It has been accepted for inclusion in Michigan Legal Studies Series by an authorized administrator of University of Michigan Law School Scholarship Repository. For more information, please contact mlaw.repository@umich.edu. 


\title{
MICHIGAN LEGAL STUDIES
}

\author{
$=$ \\ THE PREVENTION \\ OF \\ REPEATED CRIME
}

PUBLISHED UNDER THE AUSPICES OF THE UNIVERSITY OF MICHIGAN LAW SCHOOL (WHICH, HOWEVER, ASSUMES NO RESPONSIBILITY FOR THE VIEWS EXPRESSED) WITH THE AID OF FUNDS DERIVED FROM GIFTS TO THE UNIÚERSITY OF MICHIGAN BY WILLIAM W. COOK 
MICHIGAN LEGAL STUDIES

Hessel E. Yntema, Editor

Discovery Before Trial

George Ragland, Jr.

Torts in the Conflict of Laws

Moffatt Hancock

The Amending of the Federal Constitution

Lester B. Orfield

Review of Administrative Acts

Armin Uhler

The Prevention of Repeated Crime

John Barker Waite 


\title{
THE PREVENTION $\mathrm{OF}$
}

\section{REPEATED CRIME}

\author{
by \\ JohN BARKer WAITE \\ Professor of LaW, University of Michigan
}

Ann Arbor
The University of Michigan Press

Chicago

Callaghan \& Company

I 943 
Copyright, 1943

BY

UNIVERSITY OF MichIGAN 


\section{Preface}

7 HE prevention of repeated crime by persons who are already known as criminals is one of the difficult

1 problems of society. Forestalling commission of a first crime is likewise a serious problem whose solution is highly important. But it is not the same problem. Its solution depends upon prophylactic activity directed toward all individuals in the group, since each is potentially an offender, and any one of them may in time offend. Prevention of repeated crime is at least a more narrowly directed activity-which is not to say an easier one-to the extent that it is applied primarily to individuals whose identity as having already offended one or more times is known. The discussion which follows is limited to this latter problem-the prevention of repeated crime by already convicted criminals.

Henry VIII used a procedure that was highly effective, so far as it was applied. He is said to have executed 72,000 convicted criminals during the course of his reign, none of whom it may fairly be assumed ever offended again. But even he had a continuing problem in the criminals whom he neglected to excise completely. In our more modern salvaging of human wreckage we cannot, or at least we do not, subscribe the wisdom of his eliminative methods. What then is the now prevalent treatment of known offenders, and upon what theory is it based? To what extent is it satisfactory as a preventive of further crime by those who are subjected to it? Through what reasonably acceptable changes in theory and practice, and in the content of legislation, can prevention be made more effective? To these questions the writer here offers his own opinions in answer. 
As a basis for these opinions, no attempt was made to gather new data either as to the amount and type of repetitious criminality or as to methods of treatment of known offenders. Ample material to justify sound, even if disputable, conclusions has already been collected in one form or another. What follows is an attempt to correlate that existing information and to demonstrate the changes in theory, practice, and legislation which it indicates as essential to more effective social protection.

The study was begun without preconceived postulates, but the facts as they developed forced the conclusion that the traditional and still prevalent method of dealing with known criminals is disturbingly inefficient as a preventive of repeated crime, and that for the furtherance of public safety quite different ideas must be embodied in legislation and put into practice.

Though this study is concerned fundamentally with the prevention of crime, it deals only with that part of the field wherein prevention of further crime is sought through treatment of known criminals. The whole field of crime prevention is, of course, much wider than that particular part. With a reasonable degree of logical distinction, it represents five major divisions of particularized interest.

The first involves the question of what activities are to be considered as crimes and ought, as such, to be prevented. It involves the indeterminable line of distinction between immorality and crime, as well as the highly controversial question of whether all admittedly undesirable acts shall be repressed by the same socially applied deterrents; or whether all shall be dealt with, some as wrongs calling only for compensation to the individual, and others as offenses requiring that the offender respond in liability to the group.

The second division assumes that a crime has been committed and covers the various activities by which responsi- 
bility for its commission is fixed upon a particular individual.

The third and fourth divisions assume certain activities as definitively criminal and involve the procedures by which organized society seeks to forestall their perpetration.

This prophylactic, preventive activity is of two essentially different types. One type seeks to prevent crime by correcting or alleviating the social and economic conditions which cause crime through their pressure upon the individual. Of this type are efforts toward slum clearance, unemployment insurance, community facilities for lawful expenditure of surplus energies, prohibition of the manufacture or sale of intoxicating liquors.

The other type of prophylactic activity, which may be called the fourth division of preventive effort, includes the preventive measures designed to operate upon the individual himself, in the hope of guiding his reactions to social and economic conditions into safe channels, or of so controlling his person in one way and another as to render his reactions harmless. Among these are training in successful self-support without recourse to crime, religious training, education generally, the development of habits of abstention from intoxicants and of other crime-avoiding habits, inducement of fear of the consequences of crime, and, as a last resort, confinement of the individual to environmental conditions in which crime is peculiarly difficult or impossible.

This fourth division may in its turn be divided into two. One comprises all such efforts-trade-training, crimepreventive medicine and surgery, teaching of temperance, education, instilling of fear-as are directed toward the group as a whole, without special regard for those who have already offended against the law. The other division comprises such activities as may be directed particularly toward prevention of repeated criminality on the part of persons who have already offended one or more times. 
It is this latter problem, this fifth division of crime preventive activities, with which this discussion is concerned-the problem of preventing repeated crime through treatment of the known criminal himself.

As is so frequently the fact where books of this type are concerned, most of the drudgery in the production of this one was by others than the nominal author. Oliver B. Crager spent many hours hunting out the statute law of the fortyeight states. Herman Marcuse read German and Italian books which have not been published in English, and some of the Spanish criminal codes, and translated pertinent excerpts. The secretaries of such organizations as the American Prison Association, and the Women's Prison Association of New York gave information freely, and the parole officials of every state answered many questions. Mary Pearce typed indefatigably. Much of what appears herein is quotation of what others have said or collected. All that I myself can fairly pretend to, is the direction of the work and the organization, analysis, and evaluation of the information collected.

John Barker Waite

Ann Arbor, Michigan

April, 1943 


\section{Table of Contents}

PAGE

PREFACE

PART I. THE PREVENTION OF REPEATED CRIME

Chapter I. The Purposes of Treatment .... 3

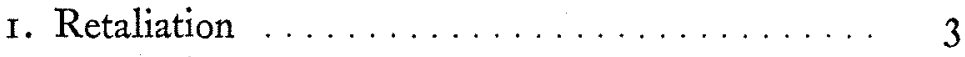

2. Prevention $\ldots \ldots \ldots \ldots \ldots \ldots \ldots \ldots \ldots$

3. The Objective of Prevention ........... Io

4. Theories of How Punitive Treatment Operates to Prevent $\ldots \ldots \ldots \ldots \ldots \ldots \ldots \ldots \ldots \ldots \ldots \ldots$

Chapter II. Failure of Punitive Treatment .. I 8 I. Failure of Punitive Treatment to Prevent Repeated Crime ................ I8

2. Reasons for the Failure of Punitive Treatment. 26

a. Deterioration of Character ........... 27

b. Neglect of Rehabilitation ............. 28

c. Lack of Assistance Following Punishment... . 30

d. Return to Freedom of Persons Known to Be Dangerous .............. $3 \mathbf{I}$

Chapter III. Changing Theories of Proper Treatment $\ldots \ldots \ldots \ldots \ldots \ldots \ldots \ldots \ldots \ldots .33$

I. Philosophic Repudiation of Punitive Methods... 33

a. Defective Use of Verbiage of Reform ..... 34

b. True Notions of Reform ............ 38

c. Theories of Continued Segregation ...... 44

2. Preservation of Punitive Values ......... 45 
Chapter IV. Legislative Authorization of

Non-punitive Treatments $\ldots \ldots \ldots \ldots \ldots \ldots .48$

I. Avoidance of Character-Destructive Contacts... 48

a. Release Without Imprisonment . . . . . . . 49

b. Release After Imprisonment . . . . . . . . 50

c. Separation of Different Types of Prisoners ... 52

2. Segregation During the Whole Period of Dangerousness $\ldots \ldots \ldots \ldots \ldots \ldots \ldots \ldots \ldots \ldots \ldots$

a. Repetitious Offender Statutes ......... 55

b. Indeterminate Sentence Statutes ........ 57

c. Statutes Permitting Segregation "Until Cured" 58

3. Rehabilitation ................. 60

a. Training in Trade Skills ............ 60

b. Trade Training-Market for Products ..... 62

c. Trade Training-Authority to Establish .... 65

d. General Education ................ 65

e. Medical and Surgical Treatment ........ 66

4. Assistance After Release from Confinement ... 69

Chapter V. Actual Utilization of Non-punitive Methods

I. The Use of Rehabilitative Training . . . . . . 74

2. The Use of Educational Rehabilitation ..... . 77

3. Assistance After Release .............. 8 8

4. The General Neglect of Preventive Procedures. . 8 $\mathrm{I}$

Chapter VI. Conclusions $\ldots \ldots \ldots \ldots \ldots \ldots 84$

\section{PART II. STATUTES AND RELATED MA-} TERIALS

Appendix A. Release Before Commitment ... 95

Appendix B. Release After Commitment ..... io6 
PAGE

Appendix C. Separation of Types of Prisoners. i I 3 Appendix D. Segregation During DangerousNESS $\ldots \ldots \ldots \ldots \ldots \ldots \ldots \ldots \ldots \ldots$ I $2 \mathbf{I}$

Appendix E. Commitment of Persons Addicted TO THE USE OF INTOXICANTS

Appendix F. Limitation of Market for PrisonMADE Goods .................... I 34

Appendix G. Permissible Sale of Prison-made Goods to Other Institutions ........... I4I Appendix H. Requirement of Purchase of Prison-made Goods by Other Institutions. . I 46 Appendix I. Authorization of the Establishment of Rehabilitative Industries ...... I 5 I Appendix J. Educational Rehabilitation ... I 165 Appendix K. Medical and Surgical Treatment. I 72 Appendix L. Assistance to Persons Released on Parole . . . . . . . . . . . . . . . I 82

Appendix M. Assistance to Persons Discharged FROM CUSTODY ..................... 194 Appendix N. Assistance Actually Rendered ..'205 Appendix O. Prison and Relief Associations in the United States and Canada ........ 2 I 7 


\title{
PART I
}

\section{THE PREVENTION}

\author{
OF
}

REPEATED CRIME 


\section{Chapter I}

\section{The Purposes of Treatment}

\section{RETALIATION}

$\mathrm{H}$ ISTORICALLY the treatment of known criminals has always been predominantly punitive. But one punishment has always been crime prevention. On the contrary, the asserted motivation of punishment and its philosophic justification have at times been wholly retrospective. For a while it was thought of not at all as a preventive procedure, but merely as a means of exacting expiatory suffering. Its purpose as then conceived is expressed in the simplicity of childish rhyme more clearly than in much of more mature philosophical disquisition:

"Tit for tat; tit for tat.

Kill my dog, I'll kill your cat."

The reason why society itself, in its group organization, took over the function of thus exacting retribution, instead of leaving that task to the individual who had been injured, is far from clear. The desire by an individual that retribution be suffered for injury done is comprehendable. But insistence by the whole social organization that it be suffered must spring from other motivations than those which influence the individual. Just what the group motivations may have been is probably matter for ex post facto rationalization, rather than any real knowledge. Various explanations have been put forth. As one writer expresses it:

"The demand that a crime be atoned for is a reaction against the pressure of our own impulses coming from within, while revenge is a reaction against the assailant from without; 
we thus can distinguish two fundamental sources for the origin of the institution of punishment; the inner demand that a violation of law be atoned for, and the tendencies of revenge. - . Both voices, that of expiation and that of retaliation, are identical psychological processes, but they differ in the accentuation of direction . . . the voice of expiation is addressed more directly to our own instinctual drives; that of retaliation is directed against the offender himself.

"From the standpoint of the psycho-economics of our life, the institution has yet another meaning; it presents a socially acceptable outlet for our own aggressions, the asocial nature of which prevents them, as a rule, from being lived out freely; normally they remain repressed. Hence, the institution of punishments represents a compensation, as it were, for the restrictions one puts on one's own sadism, and the identification of the righteous member of the community, with the latler's punishing functions, helps him to live out his own aggressions in an acceptable fashion. . . ."

This sounds rather more learned than convincing. Sir James Stephen says the same thing more simply, and perhaps more convincingly_-"The criminal law stands to the passion of revenge in much the same relation as marriage to the sexual appetite." 2

Other astute writers have suggested that organized society itself took over the function of imposing retribution simply because it recognized that retribution was demanded by its component individuals and felt that it could satisfy that demand by its own action, with less ultimate disorder than if satisfaction were left to individual effort. ${ }^{3}$ Certainly the theory that state imposed punishment tends to prevent individual disorder is now a commonplace justification for the continued

${ }^{1}$ Franz Alexander and Hugo Staub, The Criminal, the Judge, and the Public, translated from the German by Gregory Zilboorg (1931) pp. 220, 221 .

${ }^{2}$ Sir James Stephen, General View of the Criminal Law of England, London (1863) p. 99 .

${ }^{3}$ Oliver Wendell Holmes, Jr., The Common Law (188I) p. 4I : "If people would gratify the passion of revenge outside of the law, if the law did not help them, the law has no choice but to satisfy the craving itself, and thus avoid the greater evil of private retribution." 
use of punishment. In all probability, however, the system of imposing punishment through governmental activity, instead of leaving it to individual effort, sprang from factors and motivations too complex and too subtle in their effects for accurate determination.

Whatever the explanation, the fact nevertheless remains that the traditional treatment by society of known criminals has been, as it still is, punishment. Moreover, for a considerable period of time and in widely prevalent philosophy, the purpose of socially imposed punishment was assumed to be retributive. Its fundamental justification was retrospective, not prospective. It was thought of as a method of imposing retribution and not as a means of preventing repeated crime. This retributory theory was not even then the only philosophy of punishment, of course, but it was sufficiently dominant to have left its mark upon the conventional thought of the present. Because it does still affect both present thought and present practices, the differentiation between punishment as a process of compelled expiation and punishment as a preventive of future crime is important enough to warrant some elaboration. 'To that end a quotation which epitomizes the philosophy of the retributive theory is illuminating:

"Man is an entity which has its own intrinsic value; (and quoting Immanuel Kant) ${ }^{4}$ 'one man ought never to be dealt with merely as a means subservient to the purpose of another.' This principle served not only as a basis for his humanitarian philosophy, but also as the point of departure for his penal

${ }^{4}$ See Immanuel Kant, The Philosophy of Law, translated from the German by W. Hastie, Edinburgh (1887) pp. 195, 198. "Judicial Punishment can never be administered merely as a means for promoting another Good either with regard to the Criminal himself or to Civil Society. ... Even if a Civil Society resolved to dissolve itself with the consent of all its members -as might be supposed in the case of a People inhabiting an island resolving to separate and scatter themselves throughout the whole world-the last Murderer lying in prison ought to be executed before the resolution was carried out. This ought to be done in order that every one may realize the desert of his deeds, and that bloodguiltiness may not remain upon the people; for otherwise they might all be regarded as participators in the murder as a public violation of Justice." 
theory which is utterly devoid of humanitarian considerations. Since Kant assumes that man should not be used as a mere means, he maintains that even when being punished man should not be used as a means to an end, neither to the end of reforming society nor even to the end of reforming the criminal himself. Punishment, then, finds its justification only in the principle of justice, which requires that a person who has committed a crime shall be punished. In other words, punishment has its raison d'être not in any future effect upon which it may be directed, but only in the criminal act by which it is preceded.

"Partly in harmony with Kant's views is the penal theory of another great German philosopher, Georg Wilhelm Friedrich Hegel ( I 770-I 83I ). He, too, advocates an absolute theory, in that he justifies punishment not as a means to influence either society or the criminal, but as an act of retribution. However, the reasoning on which this thesis is based is quite different from Kant's.

"In the first place, if punishment were an attempt at exercising influence on people, either on the criminal or on others, it would be based on the assumption that man is not free. This, Hegel objects, would violate the principle that right and justice must have their seat in the free will, not in a restriction of the will. To use punishment as a threat by which to enforce law would be much the same as to raise a cane against a dog. Man, however, must not be treated as dog, but with due accordance to his dignity and honor.

"According to absolute theories as they are exemplified in Kant's and Hegel's views, punishment looks back to the past, so to speak, being a reaction of society to an occurrence that has taken place in the past.

Heinrich Oppenheimer, in discussing these various philosophies of punishment as an objective in itself, rather than as a means to an end, finds that they set up five different justifications:

"I. It is in the fulfilment of its divine mission that the state dispenses punitive justice. To punish criminals is a re-

"Werner S. Landecker, "Criminology in Germany," $3^{5}$ J. Crim. L. $55^{1}$ ff. (194I). 
ligious duty. This is the theological view of punishment, of which the most uncompromising advocate is Joseph de Maistre.

“ 2 . The stain of guilt must be washed away by suffering in fulfilment of one of those metaphysical laws the meaning of which man, as a finite being, cannot comprehend, but to which he must yet conform, since his own infinite nature makes him part of the order of the universe of which that law is an expression. This is the expiatory theory of punishment according to the version of Joseph Kohler.

"3. The moral law, which is binding on all rational beings, prescribes that crime shall be visited with punishment. The conception of punishment as a moral necessity has found in Kant its classical interpreter.

"4. Crime postulates punishment as its necessary logical complement. This is the root-idea of Hegel's theory of punishment.

"5. A misdeed displeases and continues to offend our. sense of harmony as long as it remains unrequited. It is the function of punishment to resolve the discord and so to satisfy an urgent want arising within our aesthetic consciousness.

This notion that the proper method of treatment of a known offender is punishment, and that the primary reason for punishing is the infliction of deserved retribution, or the exaction of due expiation, is not confined to the writings of philosophers. It is found pervasively in the written opinions of judicial decision and in the statutory enactments of legislatures. Thus, we find the supreme court of West Virginia stating: "Defendant was found guilty of murder in the first degree and adjudged to be hung in expiation of the crime." " Again, in a New Jersey case, we find a court denying the right of the New Jersey court to impose punishment for a murder when the blow had been struck in New York, although the

${ }^{6}$ Heinrich Oppenheimer, The Rationale of Punishment, London (I913) p. 182 .

7 State v. Angelina, 73 W. Va. 146, 80 S. E. 141 (1913); present author's italics. 
death had occurred in New Jersey, on the argument that "If she (New York) does not choose to avenge it, it is not for us to step in and do it for them." 8

That certain modern statutes providing for the treatment of known offenders are predicated, partly at least, upon the theory of retaliation for injury accomplished as distinct from a theory of prevention, is indicated by the Michigan law concerning punishment for attempted crime. This statute reads as follows:

"Any person who shall attempt to commit an offense prohibited by law, and in such attempt shall do any act toward the commission of such offense, but shall fail in the perpetration, or shall be intercepted or prevented in the execution of the same, when no express provision is made by law for the punishment of such attempt, shall be punished as follows: I. If the offense attempted to be committed is such as is punishable with death, the person convicted of such attempt shall be guilty of a felony, punishable by imprisonment in the state prison for not more than ten years; . . . 3. If the offense so attempted to be committed is punishable by imprisonment in the state prison for a term less than five years . . . the offender convicted of such attempt shall be guilty of a misdemeanor, punishable by imprisonment in the state prison or reformatory not more than two years or in any county jail not more than one year ... ..; but in no case shall the imprisonment exceed one-half of the greatest punishment which might have been inflicted if the offense so attempted had been committed." ${ }^{\theta}$

Obviously this apportionment of punishment can be explained only by an assumption that to some extent it is designed for retribution. If the law's purpose were merely preventive, it would apply to the act done the same consequence, regardless of whether the act were successful or unsuccessful,

${ }^{8}$ State v. Carter, 27 N. J. L. 499 (1 859 ); present author's italics.

${ }^{9}$ Michigan, 3 Comp. Laws (1929) sec. 17 I $5_{5-92}^{-9}$ (Michigan Stats. Ann. $\$ 28.287$ ). 
since its objective would be the prevention of acts likely to result in harm. The fact that the punishment for success is twice as severe as the punishment for an unsuccessful attempt must mean that the additional suffering consequent upon success is a matter of expiation or retribution because of that success.

A clear realization of the early dominance of these retaliatory, retributive, retrospective notions of punishment is imperative, because their persistence still markedly affects both the actual practices and the philosophy of contemporary treatment of convicted wrongdoers. ${ }^{10}$

\section{PREVENTION}

Despite this hardy persistence of the retrospective purpose in the treatment of discovered criminals, some notion of a prospective function eventually gained a measure of acceptance. Punishment was still assumed to be the proper method of treatment, but the philosophy of the punishment, the theory by which its utilization was justified, altered. The merely retributory theory weakened; a preventive purpose gained acceptance.

One would like to believe that the change sprang from the practicality of social wisdom. Perhaps it did. But there is also probability in Clarence Darrow's insistence that it was mere sentimental change of alleged justification, without real alteration in objective. His cynical suggestion is that:

"Most people are now ashamed to admit that punishment is based on vengeance and, for that reason, various excuses and apologies have been offered for the cruelty that goes with it. Some of the more humane, or 'squeamish,' who still believe in punishment, contend that the object of this infliction is the

10 For an excellent discussion of the various utilitarian motivations which have affected the manner of retaliation at different periods, see Georg Rusche and Otto Kirchheimer, Punishment and Social Structure (1939). 
reformation of the victim. . . . A much larger class of people offers the excuse that punishment deters from crime. In fact, this idea is so well rooted that few think of questioning it. . . . (But) punishment means that the suffering by the victim is the end, and it does not mean that any good will grow out of the suffering." 11

Nevertheless, for whatever reason, the philosophy behind the conventional treatment of known criminals has markedly changed. The treatment is still punishment, but the punishment is justified on a theory that somehow or other further crime can thereby be prevented. Its motivation, or alleged motivation, has become at least partly prospective. This, to be sure, is the revival of an older philosophy, not the origin of a new one. Lucius Annaeus Seneca wrote as early as the first century:- "We will not punish a man because he hath offended, but that he may offend no more; nor does punishment ever look to the past, but to the future; for it is not the result of passion, but that the same thing may be guarded against in time to come." ${ }^{12}$ But at least the reviving notion of prevention as the purpose of punishment was a change from the retributive philosophy which it was supplanting.

\section{THE OBJECTIVE OF PREVENTION}

However, despite this recrudescence of the notion that punishment as a consequent of crime ought to be used as a preventive measure, not merely as a retributive one, the precise objective of the preventive activity remained what Max

11 Clarence Darrow, Crime, Its Cause and Treatment (1922) pp. 19, 21, 26.

12 Nor was the thought original even then. Plato, some 400 years before, has Protagoras comment: "No one punishes a wrongdoer from the mere contemplation or on account of his wrongdoing, unless one takes unreasoning vengeance like a wild beast. But he who undertakes to punish with reason does not avenge himself for the past offense, since he cannot make what was done as though it had not come to pass; he looks rather to the future, and aims at preventing that particular person and others who see him punished from doing wrong again." 
Beerbohm might have described as inenubilous. The desired end was conceded to be reduction in the amount of crime, that was well enough agreed; but whether it was primarily reduction of further crime by the person punished, or primarily reduction of possible crime by persons who witnessed the suffering of the person punished, was by no means precisely conceded. As a matter of fact, this duplicity of objective appears not ever to have been precisely discussed to any great extent. It must have been realized, but it has been seldom considered.

Yet, obviously, punishments designed for the one purpose may not be well suited to the other. Excision of an offender by death would, of course, serve both; it would effectively preclude repetition by its victim and it might more or less effectively deter others from similar conduct. But other, less drastic types of punishment are not so well adapted to attainment of both objectives. On the contrary, a particular penalty - the amputation of a hand, for example-well calculated to inspire a preventive fear in others, far from preventing repetition of crime by its victim, might effectively force him into further crime as the only practicable means of existence. And from the opposite point of view, a peculiarly mild penalty, or the abstention from any penalty, whereby the particular criminal could be encouraged and aided to refrain from crime, might be suspect as an encouragement to others, who observed that leniency, to risk the commission of crime.

When the philosophy of punishment was wholly retrospective, and its purpose was no more socially directed than the infliction of deserved retribution, the selection of proper punishment was relatively easy and uncomplicated. The punitive authorities had only to determine how much suffering the particular wrongdoing, or the particular wrongdoer, deserved. There was a problem whether punishment was to be apportioned in relation to the offensiveness of the act, or in relation 
to the wickedness of the actor. But the choice of determinants in that respect had little theoretical connection with the public safety. In that sense, it was a somewhat academic problem.

But the later assumption that punishment was prospectively purposed, and should be designed for the prevention of further crime, immediately brought out from the ivory tower into the realm of practicalities the problem of what should be its character. The new philosophy brought the problem into the field of practical public policy, but the exponents of that philosophy did not solve the problem. Indeed, they rarely even postulated the problem in clear perspective. The retributive notion, which was still by no means a wholly obsolete philosophy, kept intruding itself upon the preventive notion. Discussion of wrongs which ought to be made punishable for the sake of prevention was confused with ideas concerning wrongs which ought to be punished because they called for expiation. Thus the question of what type of activity ought to be punished was itself confused. And when it was conceded that a particular type of act should be punished, the quantum of punishment was disputed without specific definition of the purpose of the penalty as retribution or prevention. Even when punishment was thought of as a merely preventive measure, conflict arose over its use as a horrendous example to others or as an effective control directed at the conduct of the punishee himself. Thus the whole matter of punishment was-as, indeed, it still is-twice confounded.

Nevertheless, out of this welter of conflicting ideas and confused expression there did come into more general acceptance the revived philosophy that punishment ought to be for the purpose of preventing further crime by either the person punished or the persons who learned of it.

As early as $I 763$ Beccaria set up his thesis that "every punishment which does not arise from absolute necessity . . . is tyrannical. . . . It is upon this, then, that the sover- 
eign's right to punish for crime is founded; that is, upon the necessity of defending the public liberty, entrusted to his care, from the usurpation of individuals; and punishments are just in proportion as the liberty, preserved by the sovereign, is sacred and valuable." Jeremy Bentham, too, declared it to be axiomatic that punishment be used as a means of preventing crime; hence, that the endeavor of the legislator should be to ascertain what acts would be more hurtful to the common good than beneficial and to devise for those particular activities a form of punishment necessary to deter their commission.

In more modern verbiage, von Hentig repeats the proposition, saying:

"Flight from a destructive stimulus is one of the most decisive reactions of living matter, in so far as it has developed stimulus-conveying organs and mechanisms of movement. In sudden withdrawal from the destructive sphere, the sensory touch of many animals offers a preliminary and abbreviated act of flight. The far-reaching senses of smell, hearing, and sight apprehended the threatening stimulus, while it is still in the neighbourhood of the body, thus allowing of a timely parrying movement. Again, there are deposited in the brain countless condensed experiences of situations which threaten life; thus the conception of danger sets the adequate reaction in motion long before its actual approach. This is the strongest tendency of all life, and with it the social contrivance of punishment reckons.

"Punishment means the establishment of artificial danger. Punishment is organized hurt, an impairment of life organized in the form of laws, which society consciously uses to train humanity to avoid certain possible courses of action potentially injurious or hostile to itself. Punishment is imitation of precedents which in real life are hourly repeated: here lurks the injurious agent, and there, guarded by man's living senses, wait the motor functions, and over both mechanisms is their great co-ordinator, the Brain." ${ }^{13}$

${ }^{13}$ Hans von Hentig, Punishment, London (1937) p. I. 
Perhaps the simplest expression of the whole idea is the straightforward declaration in the Constitution of Pennsylvania of 1776 , section 39 , that "To deter more effectually from the commission of crimes, by continued visible punishments of long duration, and to make sanguinary punishments less necessary; houses ought to be provided for punishing by hard labour, those who shall be convicted of crimes not capital; wherein the criminals shall be imployed for the benefit of the public, or for the reparation of injuries done to private persons. And all persons at proper times shall be admitted to see the prisoners at their labor." ${ }^{14}$

14 Though the progress of enlightened thought has thus tended toward predication of the use of punishment upon the pragmatic justification of prevention of crime, a definite reversion to the older notion of punishment as an end in itself, under the nomenclature of retribution or expiation, is apparent in the philosophy of some recent German pronouncements.

According to Landecker, "With the advent of Hitlerism, German penal theory and practice have returned to the idea of punishment as retribution. This trend has found its legal expression in an act in which penal servitude is called a means to make the offender atone for the wrong he has committed. Accordingly, in an official publication of the National Socialist Party, punishment is defined as 'retribution for the offense by an injury imposed upon the offender.'

"How can we account for this revival of the dark ages in German penology? By writers who can be considered thoroughly permeated with current trends of thought in Germany we are told that the idea of retribution is an essential element of German culture. The demand for atonement, it is stated, is as old as the German people; this demand will prevail as long as the German people will exist. Says the writer, Under-secretary of State in the German Department of Justice: 'Maybe the desire to have the offender atone for his deed cannot be based on logical or philosophical grounds, but it lives in us, and that is enough.' He finds the justification of punishment in what he calls 'a refined urge for vengeance.' Similarly, in a publication of the official 'Academy of German Law' it is pointed out that the legal penalty which is rooted in German legal 'feeling' is retributive in nature. In typical Nazi phraseology, the idea of retribution is called 'one of the deepest world wisdoms, an immortal principle of justice, springing forth from the elementary depths of the uncrippled German folk-spirit.'

"What appears thus in the guise of a flowery romanticism is in reality a methodical attempt to popularize Nazi penal methods and the Nazi system in general by an appeal to the most crude and cruel impulses of man. This political 'philosophy' has found its most cynical expression in a discussion of capital punishment, written by the Under-secretary of State in the Department of Justice, Mr. Freisler. After having discarded other techniques of execution, the writer finally arrives at the alternative of the guillotine or the axe. Which deserves preference? Freisler decides for the axe because, as he 
But though the notion of crime prevention thus supplanted the philosophy of retribution for wrong committed, it is noteworthy that the concept was almost invariably that of preventing crime by those who witnessed the punishment, with little thought for the repetition of crime by the person punished.

\section{THEORIES OF HOW PUNITIVE TREATMENT OPERATES}

TO PREVENT

The simple notion that punishment can be effective as a preventive of crime by making the evil of unpleasant physical consequences outweigh the hope of possible gain, is not without its overlay of more elaborate theory. One proposition, for example, predicates the deterrent effect of punishment not upon fear of physical suffering so much as upon unwillingness to incur the reprobation and contumely of one's fellow human beings-consequences which are both created and connoted by the infliction of punishment. The force of public opinion, rather than the fear of pain, is thus postulated as the true preventive factor. It is interesting to note that the Soviet criminal law so far gives recognition to this theory as to provide that the punishment for certain offenses may be in the form of a "public rebuke." ${ }^{15}$

Still another theory predicates much of the crime-preventive force of punishment not at all upon fear as such, neither fear of physical suffering nor fear of public opinion, but upon the creation of subconscious motivations which perhaps cannot be precisely characterized. It recognizes that a large part of conduct is not a calculated response to the gain or profit of particular conduct, but is rather a habit of conformance to established notions of moral conduct. Punishment is not the factor which compels conformance with those ideas of proper says, 'decapitation by axe better suits the German spirit."' Werner S. Landecker, "Criminology in Germany," 3 I J. Crim. L. 55r, 557 (r941).

${ }^{15}$ Judah Zelitch, Soviet Administration of Criminal Law (193I) p. 81 . 
conduct, according to this theory, but it is one of the numerous factors by which the ideas themselves are created and defined. Just why individuals do conform to these established notions of proper conduct, the theory perhaps does not make clear. But it assumes existence of the tendency toward conformity, and postulates the preventive effect of punishment upon its operation in giving form and clarity to the conduct with which conformity is desirable. We find the thought thus expressed, for instance, by Sir James Stephen:

"Bentham . . . says that if a fine of a shilling was as efficient in preventing murder as the punishment of death, a fine of one shilling would be the proper punishment for murder, and anything further would be unjustifiable cruelty.

"It is possible that by giving an unnaturally wide meaning to common words this statement might be so explained that most people would agree with it. If, for instance, a fine of a shilling were, for some reason, generally recognised as embodying the common feeling of hatred against assassins, and moral indignation at assassination, as fully as the infliction of a shameful death, Bentham's statement might be true; but to discuss so unnatural a supposition would be a waste of time. Probably, however, Bentham's meaning was that if murderers in general feared a fine as much as death, they ought, upon conviction, to be fined instead of being put to death, although putting them to death would be more in accordance with the moral sentiments of the community at large than fining them.

"If this was his meaning I dissent from it, being of opinion that if in all cases criminal law were regarded only as a direct appeal to the fears of persons likely to commit crimes, it would be deprived of a large part of its efficiency, for it operates not only on the fears of criminals, but upon the habitual sentiments of those who are not criminals. Great part of the general detestation of crime which happily prevails amongst the decent part of the community in all civilized countries arises from the fact that the commission of offences is associated in all such communities with the solemn and deliberate infliction of punishment wherever crime is proved. The sentence of the law is to the moral sentiment of the public in relation to any offence what a seal is to hot wax. It converts 
into a permanent final judgment what might otherwise be a transient sentiment. . . . In short, the infliction of punishment by law gives definite expression and a solemn ratification and justification to the hatred which is excited by the commission of the offence, and which constitutes the moral or popular as distinguished from the conscientious sanction of that part of morality which is also sanctioned by the criminal law. The criminal law thus proceeds upon the principle that it is morally right to hate criminals, and it confirms and justifies that sentiment by inflicting upon criminals punishments which express it.

"I think that whatever effect the administration of criminal justice has in preventing the commission of crimes is due as much to this circumstance as to any definite fear entertained by offenders of undergoing a specific punishment." 16

The same notion is expressed perhaps even more definitely by Aschaffenburg, who says:

"The theory that considers a penalty necessary only 'Quia peccatum est,' is based on wrong assumptions.

"The deterrent effect of punishment should be active in two directions. It must impress itself on the consciousness of the people at large, and thus act as a preventive, and, through the punishment, it must be a warning to the individual and must thus restrict him from further evil deeds. . . . Greater, however, than the value of the threat of punishment in the individual case is its educational value for the whole view of life held by the people.

"The stamping of an act as an offense the commission of which the State will prosecute with unrelenting severity, immediately arouses the feeling that the act is unsuitable, inadmissible, disreputable, contrary to duty.

"Thus, general prevention operates rather quietly, slowly, and penetratingly, making the consciousness of right sharper, intensifying the general feeling for right and wrong, and is thus rather educative than directly deterrent." 17

${ }^{16}$ Sir James Stephen, 2 History of the Criminal Law of England, London (1883) p. 79 .

${ }^{17}$ Gustav Aschaffenburg, Crime and Its Repression (I913) p. 259 ff. 


\section{Chapter II \\ Failure of Punitive Treatment}

\section{FAILURE OF PUNITIVE TREATMENT TO PREVENT REPEATED CRIME}

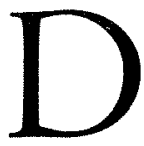

ESPITE all the theories of how punishment for crime operates to prevent crime, the fact is inescapable that on no theory does it accomplish that purpose with any reasonable degree of satisfaction. It is not an effective preventive either of first crime, or of repeated crime.

It is true that a great many persons never do commit crime, and also true that many who have been punished for crime do not thereafter offend again. How much of this abstention from wrongdoing can be attributed to the process of punishing those who do offend and are caught, there is no possibility of determining. Influences other than the use of punishment are also at work-all those imponderable factors of religion, of training in the home and in the schools, of conduct habits developed from early childhood, and of other conditioning forces by which conduct is controlled. To what extent a life of obedience to the precepts of the law is attributable to these latter, and how far it is produced by the infliction of punishment upon those who depart from the law's requirements, is at best a matter of speculation.

But if one were to attribute all abstention from crime to the effect of punishment of offenders who are convicted, the record would still be shockingly unsatisfactory. From the studies of Thorsten Sellin for The American Law Institute it appears that one man is now actually in jail out of every 225 over sixteen years of age who are free. Obviously many who now are free have been in jail and others will eventually be impris- 
oned. Hence criminologists estimate that sooner or later from one to two per cent of the population commits a crime serious enough to call for punishment by imprisonment. If this be true, the prevention of crime through the use of punishment is scarcely to be considered satisfactory.

But what is still more serious, because even more definitely a failure to accomplish its assumed objective, is the demonstrable ineffectiveness of the merely punitive process in preventing repetition of crime by the very individuals who have been subjected to it. Again the fact that some people who have been subjected to punishment do not thereafter commit further crime is undeniable, whether their conduct can be properly attributed to the punitive treatment or not. But it is equally undeniable that an appalling number of those who are punished do repeat their criminality, time and again, despite that treatment. Whatever of good the punitive process may possibly do in prevention of repeated crime, the extent to which it fails in its purpose is so widespread and so commonplace as to leave no room for doubt that it is not a satisfactory method of treatment of discovered criminals.

In the verse of Ogden Nash:

"Experience is a futile teacher, Experience is a prosy preacher, Experience is a fruit tree fruitless,

Experience is a shoe-tree bootless.

"The burnt child, urged by rankling ire,

Can hardly wait to get back at the fire,

And, mulcted in the gambling den,

Men stand in line to gamble again.

"He who has never tasted jail

Lives well within the legal pale

While he who's served a heavy sentence

Renews the racket, not repentance. . . ."18

${ }^{18}$ From "Experience to Let," I'm a Stranger Here Myself (1939) p. 5 1. 
Regardless, at the moment, of the reason, the fact exists. ${ }^{19}$ This, be it repeated, is not an assertion that punishment fails completely to prevent repeated crime. On the contrary, it must have some effect, slight though it be. Certainly many persons who have once been punished do in fact thereafter abstain from crime, and it is possible that this abstention is the result of the punishment. To what extent those who have been punished do so abstain, the collected data leaves in a cloud of uncertainty and dispute. Sheldon and Eleanor Glueck, who followed the careers of 422 young men for five years after their release from the Massachusetts Reformatory, found that 333 had committed new offenses to a total of I,OI 4 times, a third of them serious crimes-" 89 were successes;" in the job of abstention from crime " 7 I were partial failures; 262 were total failures." 20 On the other hand, Mr. E. R. Cass, secretary of the American Prison Association, reports that out of 2,257 parolees from New York penal institutions, "the record of five years shows a total of $82 \% / 2$ per cent who were not convicted of any crime whatsoever while they were on parole." ${ }^{21}$ He does not say how many reverted to crime after the parole supervision was ended, and the "unknown factors" involved in Mr. Cass' figures make them less persuasive than the carefully checked data of the Gluecks. But despite all such uncertainties as to how much preventive

${ }^{19}$ There is, of course, nothing original in this assertion by the present writer. Compare, from many essentially similar references, William Healy and Augusta Bronner, Delinquents and Criminals (1926) ,p. 229:

"There still seems to be a lingering notion among those who are poorly informed that punishment such as can be given under modern conceptions of humanitarianism forms an adequate program for older offenders. The hard facts of recidivism completely disprove this. Whether we speak of the juvenile or the adult offender we may fairly state that punishment in very many cases is no more reformative or deterrent than when it is used in family life. And there can be no doubt on the part of those of us who have occasion to study many instances of family life that where punishment is the only corrective the most unfortunate delinquent trends and mental attitudes are created."

${ }^{20}$ Sheldon and Eleanor Glueck, Later Criminal Careers (1937) p. I 1.

21 The Prison World, July-August, $194 x$. 
effect punishment does in fact show, the larger fact still remains that its total effect falls far short of anything that could be considered reasonably satisfactory.

Specific instances are of little worth as proof, but they do have a modicum of value as illustration of what is indicated by data of broader scope. Those which follow are picked casually, without pretense of study to ascertain how far they are precisely representative. Because misdemeanants are imprisoned for shorter periods than felons, they have opportunity for more rapidly repeated wrongdoing and, as might be expected, their records of convictions run numerically higher. In the Detroit area one finds these:

W. E. I 2 punishments for tampering with an automobile, 9 for larceny, 4 for other offenses.

F. R. I7 punishments, 6 of them on felony charges.

C. S. after 30 years in prison for 4 sex offenses, sentenced a fifth time at 59 years of age.

Kate R. 50 convictions in 30 years, a total of 9 years in jail.

J.W. T. 50 convictions for crime ranging from petty misdemeanor to felony.

F. E. 76 convictions carrying a total of over 4 years in jail. Eddie M. Ioo successive convictions. As he is now $6 \mathrm{I}$ years old and his latest offense was one for which he was sentenced to from 5 to ro years in the penitentiary, his record may be at an end.

These individual records of persistence in felony despite punishment are from Chicago:

C. O'N. I9I2, fraud, I-ro years; I 919, fraud, 5-ro years; r927, fraud; 1933, fraud, discharged February, I940; July, r 94r, fraud, I-14 years.

E. C. I 930, robbery, I-20 years; I 936, robbery armed, I year to life, paroled July, I940; February, r94I, attempted robbery, $\mathrm{I}-5$ years.

O. D. 1922, robbery, 5-40 years; 1932, attempted murder, I-I 4 years, discharged August, I940; March, I94I, robbery armed, I year to life. 
T. O. rgor, burglary; r 902, burglary, discharged January, I 909; February, I 909, burglary, 4 years; I 9 I 2, burglary, ıo years; I 9 Io, burglary, 2-I 4 years; I 940, burglary and attempted murder.

J. N. I907, burglary, 2 years; 1908, burglary, 2 years; I 9 Io, burglary, 5 years; I 9 I 4 , homicide, Io years to life (escaped); 1915 , rape, I 2 years; 1923 , burglary, indeterminate sentence; I 929, assault; I 933, burglary, I year to life.

G.W. I9I 8, concealed weapons; I 920, larceny, 6 months; I 92 I, larceny, 6 months; I922, larceny, I year; 1923, larceny, I year; I924, burglary; I 929, malicious mischief, 6 months; I93 I, larceny, I 5 days; I93 I, mail theft, $2 \frac{1}{2}$ years; 1940 , robbery armed, life.

C. N. I933, burglary, i 8 months; 1935, burglary, 5 years; I 937, burglary, 3 years; I 940, burglary, I year to life.

C. McC. I 925, burglary, probation; 1926, auto theft, I-IO years; I930, robbery armed, I year to life; paroled October, I 939; December, r 939, robbery armed, 20 years.

The particular localized search from which the foregoing eight illustrations resulted produced in a relatively few hours a total of 95 similar cases, in none of which had less than three punishments been actually inflicted, with a median of approximately five times in jail. The futility of mere punishment as preventive of repeated crime could be thus exemplified by specific instances many thousands of times.

That such cases represent the rule rather than an exception is demonstrated by the data of wider scope. Thus, in an attempt to find out which of two Pennsylvania penal institutions was preferred as a place of sentence by state judges, an investigator happened on the fact that, out of 12,370 persons committed, I 2,028 had already served terms in one or the other and 342 had been confined in both. Moreover, I,235 of the group had been previously confined from two to five times each in those two institutions alone. That these were not cases of little social importance is indicated by the fact that 
two-thirds of the commitments were for larceny, robbery and burglary, and half the sentences were for terms of more than five years. ${ }^{22}$

So commonplace, indeed, is the repetition of offenses despite punishment, that the population of state penitentiaries is more than half composed of persons who have been in penitentiaries before. Thorsten Sellin, in his studies for the American Law Institute, found the following percentages of prisoners in penal institutions who had already experienced previous punitive confinement-and it must be remembered that because of inaccurate reporting of prior penalties the figures are somewhat less than the truth:

Federal prisons and camps

Massachusetts

$45.2 \%$

Connecticut

New York

New Jersey

64.8

56.2

Pennsylvania

55.6

Indiana

56.0

Illinois

59.8

Wisconsin

Iowa

District of Columbia

49.5

56.6

West Virginia

44. I

Kentucky

70.9

Arkansas

59.3

Oklahoma

48.7

Colorado

$2 \mathrm{I} \cdot 3$

38.1

Washington

44.2

54.8

Oregon 46.5

California

Total of all institutions

The proportion of prisoners who had committed particularly serious crime despite previous punishments was, he

${ }^{22}$ Leon T. Stern, "Effect of the Depression on Prison Commitments and Sentences," 3 I J. Crim. L. 696 (1941). 


\section{THE PREVENTION OF REPEATED CRIME}

found, even higher than that of the prison population as a whole:

Commitments to prisons and reformatories for:

Homicide

Robbery

Burglary

Embezzlement and fraud

Forgery

Rape

Violation of drug laws
Previous commitments (not necessarily for same type of crime)

$6 \mathrm{I} .7 \%$

$6 \mathrm{I} .9$

65.1

$75 \cdot 5$

77.7

58.0

$90.3^{23}$

Other reports read similarly. For example, the official report of the West Virginia Penitentiary, I 936-1939, shows:

\begin{tabular}{ccccc} 
Year & Total Commitments & \multicolumn{3}{c}{ Repeaters } \\
$3^{\mathrm{d}}$ & $4^{\text {th }}$ \\
I936-7 & IOO5 & 255 & IO7 & 3 I \\
I937-8 & I I I I & 254 & IO5 & 5 I \\
I938-9 & I I67 & 248 & I IO & 44
\end{tabular}

In addition to this number who were repeating penitentiary experience, there were in the penitentiary on June 30,1939 , 425 persons who had previously been punished by imprisonment in a state reformatory. ${ }^{24}$

The Prison Industries Reorganization Administration found that this recidivism is not confined to crimes of serious character. On the contrary, "an analysis of the Jail population on a flow basis shows about 75 percent to be repeaters who have been in the Jail or the Workhouse again and again for petty offenses. Five percent of the men released in April 1937 had each served over fifty previous commitments under sentence." 25

The unhappy conclusion to which a student of such data is almost necessarily driven is thus expressed by Mr. Sellin:

${ }^{23}$ Thorsten Sellin, The Criminality of Youth (1940) pp. 73, 85.

${ }^{24}$ West Virginia Penitentiary, Official Report and Statistics, 1936-39, p. 23 .

${ }^{25}$ Prison Industries Reorganization Administration, The Prison Problem in the District of Columbia (1938) p. 33 . 
"There is no doubt that once a person has been brought to justice, the causes that brought him there, the social stigma of conviction, and the frequently harmful instead of corrective punishment contrive to increase the likelihood of his committing a later crime; i.e., a person once punished for a crime is from a statistical point of view much more likely to commit a crime than one who has never been punished. In other words, a person is more likely to become a second offender than a first offender." ${ }^{26}$ Indeed, he concludes, so definitely not preventive is punishment that one who has been punished for crime is seven times more likely to commit repeated crime than one who has not committed crime at all. ${ }^{26 a}$

${ }^{26}$ Thorsten Sellin, The Criminality of Youth (1940) p. 102.

${ }^{26}$ Cogent data to the same general effect appear in Sheldon and Eleanor Glueck's publications-One Thousand Juvenile Delinquents (x934); Juvenile Delinquents Grown Up (1940); 500 Criminal Careers (1930); Later Criminal Careers (1937).

It goes without saying that this failure of the punitive system is by no means characteristic only of the United States. So widespread is it that data from other countries would be supererogation. But the first few paragraphs of the Report of the Departmental Committee on Persistent Offenders, presented by the Secretary of State for the Home Department, London (1932, Cmd. 4090 ), is an effective statement.

"The need for an enquiry into the methods of dealing with persistent offenders arises not because the number of criminals in this country is large, but because a large proportion of the persons convicted of offences have been repeatedly guilty of previous offences and are neither reformed nor deterred by the sentences passed upon them. . . . In all there were 39,000 imprisonments of persons convicted of offences, but 12,500 resulted from failure to pay fines, leaving only 26,500 cases in which imprisonment was imposed without the option of a fine. . . . In 20,384 cases the offenders had been previously in prison. . .

\begin{tabular}{|c|c|c|c|c|c|}
\hline $\begin{array}{r}“ 4,740 \\
2,952\end{array}$ & had & $\begin{array}{c}\text { served } \\
6\end{array}$ & $\begin{array}{l}1 \\
2\end{array}$ & previous & $\begin{array}{l}\text { sentence } \\
\text { sentences }\end{array}$ \\
\hline$x, 949$ & « & $\ll$ & 3 & \&6 & 《 \\
\hline$I, 499$ & \$6 & \& & 4 & " & “ \\
\hline$I, 1 \pm 5$ & $\ll$ & c & 5 & " & 《 \\
\hline 3,382 & " & " & $6-10$ & « & " \\
\hline 2,622 & \&6 & $" 1$ & II -20 & \& & " \\
\hline 2,125 & c6 & " & over 20 & "6 & " \\
\hline
\end{tabular}

"The probability of relapse increases with the number of previous sentences, and a substantial part of the prison population consists of a 'stage army' of individuals who pass through the prisons again and again. . . .

"That the present methods of dealing with persistent offenders are unsatisfactory is the general burden of all the evidence we have received, whether from witnesses who have judicial or magisterial experience, or from representatives 


\section{So, what? Assuming that the punitive process of treatment} is a lamentable failure, is there reason to suppose that some other method of treatment would be a more effective preventive? Before that question can be answered one must consider particularly why the punitive method fails. ${ }^{27}$

\section{REASONS FOR THE FAILURE OF PUNITIVE TREATMENT}

\section{Punishment necessarily fails in satisfactory prevention of} repeated crime for the simple reason that while punishment may possibly beget a desire to refrain, it is not designed and,

of the police, or from prison administrators, or from social workers and philanthropists, or from medical experts and psychologists."

${ }^{27}$ In anticipation of what follows, obviously suggesting that "punishment" for crime is one thing but that equally unpleasant, equally undesired consequences to the convicted criminal are something other than "punishment," it seems wise to define that term as this writer uses it.

The imposition of suffering is punishment, or something else, depending upon the purpose with which it is imposed. Neither the wounded soldiers whose limbs were once amputated without anaesthesia, nor the "insane" persons who today are forcibly confined in "hospitals," are thought of as being punished thereby. The unwilling school-child may be punished with the birch, but he is not being punished by his compelled attendance at school. No more is the convicted criminal necessarily "punished" if, because of the fact of his offense, he is subjected to segregation from society, to compulsory education of some sort, or to corrective medical and surgical treatment. If the purpose of the treatment is primarily to cause him suffering and thereby, through its reformatory effect on him, ultimately to protect the public, it may fairly be called punishment. But if its purpose is primarily to protect the public by his segregation or education, then, though incidentally it may cause him suffering, it is no more lexicographically punishment than the enforced segregation of a smallpox victim during the period of his infectiousness is punishment.

If this be elaboration of the obvious, the explanation is made because some writers have assumed that any unpleasant, or undesired, treatment following conviction of crime is ipso facto "punishment" regardless of why the treatment is utilized. Thus Jerome Hall, "The Youth Correction Authority Act," 28 A. B. A. J. 317, 318 (May, 1942), "We may accept the pragmatic test that punishment is the deliberate infliction of unpleasant consequences by state offcials after conviction for crime." His context makes clear that in his connotation of the word, what would not be punishment if done by state officials to an ascertained paranoiac would be punishment if done in the same way, for precisely the same purpose, to an ascertained criminal.

It is true that the consequences imposed on ascertained criminals have heretofore been primarily for the purpose of causing suffering and have, therefore, been punitive. But it does not follow that every unpleasant consequence must be called punitive no matter how different its purpose. At any rate, the distinction between consequences imposed for the purpose of causing suffering-which is the present treatment-and consequences which, though unpleasant, are im- 
so long as it remains punishment, cannot be designed, to foster an ability to refrain.

Neither is punishment, as such, suited to the protection of the public against criminals who are known to be undeterred and undeterrable by punishment.

\section{a. Deterioration of Character}

As it has been traditionally executed and is still commonly applied, the punitive process is not calculated to strengthen even the desire to live in conformity with law. Theoretically speaking, punishment might be individualized in its application, as well as in its character, but the dictates of practical necessity have made it in fact a mass procedure in which whole groups of persons subjected thereto are dealt with in a body. But mass punishment inevitably tends to the deterioration of character, rather than its improvement. When innocence is contaminated by wickedness, when unsophistication is educated by experience, or when casual wrongdoing is encouraged by evil association to the point of a pervading viciousness, the very desire to abstain from criminality may be utterly destroyed. Fear, perhaps, may be instilled; but not a wish to conform with righteousness. And fear, without willingness toward law-abiding conduct, is proved by history a futile weapon of protection.

That character degradation as a consequence of prevailing mass methods of punishment is no mere remote possibility, but a very real actuality, is the opinion of every thoughtful investigator. "Among all environmental conditions which tend to create anti-social conduct none is better known than those which surround the offender during custody. The very individual whom society would turn into the paths of rectitude is often made much worse by experiences forced upon him." 27a

posed primarily for other purposes, is what the writer has in mind in suggesting that treatment other than punishment must be considered.

${ }^{27 *}$ William Healy, The Individual Delinquent ( 1929 ) p. 3 ro. 
This smothering of instincts toward proper conduct by the overlay of close association with evil and viciousness of ex-. ample may not be an unavoidable concomitant of punishment for crime. Conceivably, such individualization of treatment might be possible as would evoke all the desirable responses without at the same time counteracting them with destructive influences. But as a practical matter, that process has not been put into operation. Save in occasional institutions, neither actual practice, nor the law itself, makes more than a pretense of protecting potential rectitude of conduct from the destructive association of penitentiary existence. Thus even in its hope of begetting a wish to live within the law, the merely punitive process defeats itself.

\section{b. Neglect of Rehabilitation}

Obviously, no system of treatment which aims at prevention can even theoretically be of satisfactory effectiveness so long as it returns its subjects to society no better fitted to live a law-abiding existence than they were before the treatment began. All the alleged causes of crime boil down in the ultimate to two types-either the individual has yielded to wrong doing because he was subject to pressures not affecting those who do not commit crime, or else his resistance has been less than that of others who do successfully resist similar pressures. Although no method of treatment of the individual can alter the external pressures by which he will thereafter be driven, a properly designed treatment can effectively influence his reaction to those pressures. It may create in him an ability to evade certain influences which he lacks the capacity to resist; or, in the alternative, it may beget in him an increased capacity to resist the influences which he cannot evade. If either is accomplished, the likelihood of his abstention from repeated crime is increased. If both these 
ends are attained, his abstention is still more probable. Conversely, if neither his facility for evading dangerous pressure is developed, nor his capacity for resisting pressure to which he may be subject is increased, then certainly his capacity to abstain from crime will not be strengthened, whatever his desire thereto may be.

The system now relied upon, the punitive process, does not even in theory pretend to develop its victims' capacities. for law-abiding self-support, nor does it create in them a facility for avoiding the conditions which normally make for crime. As a punitive process it does not attempt to discover and remedy the physical or mental abnormalities which drove the individual into crime; it cannot, as a punitive proceeding, seek to improve his capacity for self-support without recourse to crime. Though it may in theory create a will to refrain, it does not create a capacity to refrain. It relies upon one thing, and one only. It presupposes that all that is necessary, or at least all that can be done, to prevent repetition of crime is to strengthen the desire to abstain.

Unfortunately, this basic assumption is fallacious, as experience has proved and statistics demonstrate. Not only are other procedures imperative, but other methods are possible. It may be quite true that we cannot generalize about the causes of crime. It does not follow, however, that we cannot determine and correct the cause in a particular case. We may concede with Messrs. Carl Murchison and A. A. Hartman that neither crime nor its repetition is usually the product of subnormal intelligence. Nevertheless, in particular instances, that may be clearly the precise reason for the wrongful conduct. So, too, we may agree with Healy and Bronner that the older idea of criminals as the mal-nourished, the physically undeveloped members of society, is no longer maintainable. Yet, beyond question in particular cases, some mal-nourishment or undevelopment may be the obvious cause of particular 
criminality. Granting, too, that Messrs. Schlapp and Smith fail to prove their thesis that most crime is the product of glandular abnormality, still no one would have the hardihood to deny that in some particular cases glandular abnormality is the cause, and a curable cause. ${ }^{28}$ The crime-productive influences of poverty, or of a sense of inferiority, can be minimized by training in the skills of earning a living.

Yet as a counter-measure to so many and so variant possible causations of crime, the punitive system offers only punishment. At most it sets up a counter-incentive. It does not and cannot, so long as it remains a punitive system, search out individual causations and eliminate them.

\section{c. Lack of Assistance Following Punishment}

A third reason for the failure of punishment to prevent repeated crime is the neglect of government actively to assist those whom it has punished in leading law-abiding existences.

For a man who has been released after punishment to live in obedience to law is more difficult than for one who has never been convicted. The stigma of a recorded conviction precludes his enlistment in the army; during a state of war it bars him from work in many "defense" activities; even in time of peace and prosperity, it seriously limits the number of employers who are willing to hire him. Those are consequences which perhaps cannot effectively be avoided by wise legislative enactment. But even if the fields of opportunity were as free to the released convict as they are for a man who has never been convicted, the obstacles facing an ex-convict who

28. Max Schlapp and Edward Smith, The New Criminology (1928). A vigorous argument to the effect that much repeated crime could be prevented by appropriate surgical and medical treatments-which would, of course, include psychiatric methods-and that such treatments are practicable even within the penal system and should be utilized, is set forth in the Report of the Departmental Committee on Persistent Offenders, presented by the Secretary of State for the Home Department, London (1932, Cmd. 4090). 
wants to go straight are peculiarly hampering. Some wealthy malefactor may find employment after release as superintendent of a friend's estate. Another may be met by a delegation of old associates who banquet him in honor of his release. But the average offender is handicapped from the moment of release. In the words of a prison administrator: "When prostitutes are sentenced to my institution, we cure them of disease; at the end of their terms we turn them on to the streets, with no money, no job, no home, no place to sleep. Is it strange that they come promptly back to us?"

For an unemployed man, or woman, to get work takes capital-money for food and a place to sleep while hunting employment; money for transportation; money to keep oneself presentable; money, often, for the tools of his trade; money for admission to a union, without whose card no one will dare to hire him. The released and out-of-work ex-convict, often frightened by the world from which he has long been excluded, needs guidance, sympathy, the intangible assistance that only humanity can give. What he cannot get from one group, he will inevitably seek from another. If the law withholds what he needs, crime may seem to offer it.

Punishment cannot furnish what he must have to keep him from crime. Some other institution can be set up for the purpose, but it will be an agency of assistance, not punishment.

\section{d. Return to Freedom of Persons Known to Be Dangerous}

If punishment itself is thus insufficient for the effective prevention of repeated wrongdoing, neither can the punitive system, after it has punished a man, keep him out of society merely because it is evident that he will commit another crime as soon as released. Eddie Murphy, for example, was sentenced, punished, returned to freedom-and promptly resentenced for further crime-one hundred times. After his 
first half score of repetitions no one could have supposed that he would not promptly offend again when released. The only possible protection of society against his repeated depredations would have been his continued segregation from society. But Murphy could not be detained for more than a short period following each offense because he was only being punished for the offense, and a penalty of long duration would have been undeserved and outrageous.

The records are filled with instances where known offenders, sentenced to years of imprisonment for heinous crime, have eventually been returned to society, not because anyone believed their release would be safe, but because the term of reasonable punishment had expired. ${ }^{29}$

Enforced segregation for ends other than punishment is commonplace. "Typhoid Mary" was held in a New York institution year after year because she was a continuing danger to public health. Insane persons are confined for life to protect the public safety. But "punishment" is limited not by what the public needs, but by what the crime will justify. Here, again, punishment is found wanting as a means of social protection.

${ }^{29}$ The case of Dominick Piccone is illustrative. Sentenced to $3 / 2$ to 4 years in the Michigan penitentiary for attempted rape of a negress, he was kept out of society as long as the law permitted. Before his release the prison psychiatrists reported that release would be definitely dangerous. "He is not frankly psychotic," they said, hence "not committable" to an institution for the insane, but he is "definitely assaultive and potentially homicidal." Yet, because his term of punishment had expired, and he was not what the law calls "insane," the prison authorities had no right to hold him longer. He was released. Within two weeks he had murdered three persons. (Associated Press, April 3, 1942). 


\section{Chapter III}

\section{Changing Theories of Proper Treatment}

\section{PHILOSOPHIC REPUDIATION OF PUNITIVE METHODS}

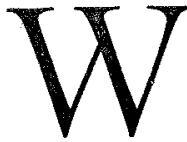

ITHIN comparatively recent years a vigorous insistence that punishment be discarded as a principal method of treatment for known criminals has become increasingly vocal. The punitive notion is still dominant, despite the shift in its justification from the purpose of retribution to the alleged purpose of prevention. ${ }^{30}$ But ideas of other, more effective, methods for preventing repeated crime are finding expression and advocacy. To some extent they may be motivated, as is occasionally charged, by a mere sentimentalist horror of the rigors of punishment. Far more often and more obviously they spring from realization of the practical futility of punishment as a preventive. But whatever the cause, an insistence on procedures more effective than mere punishment is strengthening in frequency and explicitness.

These newer proposals must not be confused with some of the older philosophy which, though it uses the terminology of "correction" instead of "punishment," is not in reality advocation of a substitute for punishment, but only of some unusual justification for its use. It is imperative to distinguish the two ideas, despite their use of words apparently similar but fundamentally different in significance. One idea conceives of reformation through suffering; the other of rehabilitation by many methods.

30 As late as April, 1940, Morris R. Cohen can devote 39 pages to discussion of "The Moral Aspects of Criminal Law," 49 Yale L. J. 987, without considering anything but its punitive aspects. 


\section{a. Defective Use of Verbiage of Reform}

An example of the verbiage of "reformation," though the idea is still punitive, is this:

"Krause, who in other respects was not an adherent of determinism, regarded punishment as a means of education (i. e., not in its nature and purpose as an evil). He who was undergoing punishment, was under guardianship like the immature. The State has the right to interest itself in the development of the immature, in the reformation of the morally depraved will. According to Krause, there can be no such thing as a legal authority to inflict evil, as such, and therefore cause suffering.

"Ahrens gives to this theory a coloring which touches even its absolute foundation; for he regards the purpose of the punishment as the restoration of the violated legal order of things. But he found this restoration of the legal order only in the personality of the criminal and not in an effect upon others. Consequently, rejecting all absolute theories (which he regards as amounting more or less to retribution), he designates his theory as the theory of reformation, and effectively defends himself against numerous obvious objections.

"Röder sought to give greater definiteness to the theory of reformation by his statement that the purpose of punishment lies in the elimination of the actually proven immoral will; wherefore, everyone may be placed under supervision (i. e., criminal supervision) exactly to the extent that he has manifested a will inclined to wrongdoing. . . . A reformatory punishment, to be consistent, can and must be pursued only so far as an improvement (presumptive, at least) is obtained; . . ." ${ }^{31}$

Verbally that sounds somewhat like segregation primarily as a means of prevention, like the utilization of rehabilitative treatments, like a re-formation of the character of the individual. But it is noteworthy that none of these writers really

${ }^{31}$ Carl Ludwig von Bar, History of Continental Criminal Law, translated from the German by Thomas S. Bell and others (Igr6) p. 444 ff. 
suggests the actual use of treatments peculiarly calculated to strengthen the individual's ability to evade certain causes of crime, or designed to remove the particular causes inherent in himself. In a merely verbal sense, they are, it is true, talking "correction." But the fundamental assumption implicit in each case is the now anachronistic one that crime and lawabiding behavior are matters wholly of free choice, satisfactorily controllable by making one choice less attractive, because of threatened punishment, than the other. Of true correction-correction of the impulses or weaknesses, correction of the conditions which exercise so great an influence upon choice-there is no realization apparent in those discussions. What they propose is in truth little if anything more than rephrasing of the idea that punishment shall be used as a means for guiding choice, rather than as a process of retribution. Jeremy Bentham lets the cat out of the bag in his statement that "When the ultimately intentional result is amendment or reformation, it is by the impression made by the action of the evil on the will of the offender that, in so far as it is produced, the result is considered as being produced. In this case the act of punishment is also termed an act of correction." ${ }^{32}$

Still other writers who might seem from their terminology, when it is divorced from its context, to be advocating correction of the causes within an individual which drive him into crime, and in this sense seem to be proposing rehabilitation rather than punishment, are in truth only discussing those causes of crime which lie outside the individual and produce the necessity for punishment. Thus, for example, Enrico Ferri writes at considerable length of what he characterizes as "penal substitutes." He says:

"Since punishments, instead of being the simple panacea ${ }^{32}$ Jeremy Bentham, The Rationale of Punishment, London (1830) p. 7 . 
of crime which popular opinion, encouraged by the opinions of classical writers on crime and of legislators, imagine them, are very limited in their deterrent influence, it is natural that the criminal sociologist should look for other means of social defense in the actual study of crimes and of their natural origin. . . These methods of indirect defense I have called penal substitutes." ${ }^{33}$

But by this phrase he does not, as one might suppose, mean anything at all in the way of rehabilitation in the broader sense of the word. $\mathrm{He}$ is not thinking of substituting something other than punishment in the treatment of the individual. On the contrary, he has in mind changes in law which would make the need for treatment of the individual less frequent. He sets out as illustrations of these substitutes such things as the amelioration of poverty by the establishment of free trade. He would prevent smuggling, also, by that means. So, too, he would prevent drunkenness by increasing the tax on alcoholic beverages and lowering it on coffee, tea, and beer. His suggestion of a "penal substitute" for the prevention of repeated forgery is not a new method of dealing with the forger, but the use of metal money, which he assumes to be difficult of counterfeiting, in place of paper money.

The last half of Ferri's book is devoted to what he calls "practical reforms." It is obvious again, however, that he does not have in mind prevention of repeated crime through reform of the individual, but is writing about reform in the content and enforcement procedures of penal law. He considers the wisdom of the extent to which the presumption of innocence has been carried; he discusses the proper structure of prison buildings; he questions the practice of dismissing prosecutions without trial; he writes of indemnification of persons wrongfully convicted through judicial error and the indemnification of victims of crime, and of the use of lie detec-

${ }^{33}$ Enrico Ferri, Criminal Sociology (1898) p. 110. 
tors. But he does not advocate a treatment different from that of punishment for the person whose guilt has been determined by reformed methods.

The persistence of the earlier expiatory, retributively punitive notion, even in comparatively modern and so-called scientific writing, is illustrated by the thesis of The Criminal, the Judge, and the Public by Franz Alexander and Hugo Staub. $^{34}$ The authors vigorously advocate psychoanalysis of known criminals. But oddly enough their proposition is not that through such psychoanalysis the specific cause of an individual's criminality may be discovered and eliminated, so that he will be less likely to offend again. On the contrary, their purpose in the psychoanalysis would be to discover why a criminal offended in order that the amount of punishment deserved by other offenders might be more fairly, more "justly" determined. "We want to understand the criminal," they say, "in order to be able to judge him correctly, so that our judgment may be just beyond question. Our assertion that our clear understanding of the criminal serves the interests of society is based on the fact that the sense of justice belongs to the most fundamental factors of human social organization; any disturbance of the common sense of justice has a destructive effect upon society." ${ }^{34 a}$

One finds essentially the same notion in the numerous dissertations by medical writers upon what they denominate "partial responsibility" for criminal acts-obviously not a partial responsibility to crime-preventive correction, but a partial deserving of the quantum of punishment imposed on normal persons. ${ }^{35}$

${ }^{34}$ Translated from the German by Gregory Zilboorg (193I).

${ }^{342}$ Ibid, p. xvi.

${ }^{35}$ Even the Italian Penal Code of 1930 which at the time of its appearance received such laudation, particularly from those persons connected with it, for its modern progressiveness, shows clearly the persistence of the retributive no- 
All such narrowly limited "reform" of prisoners, such mere pretense of alteration in treatment of convicted persons, such advocacy of the correction of social conditions in the verbiage of correcting criminals, is essentially adherent to the old, the punitive, philosophy of treatment, not representative of a new idea.

\section{b. True Notions of Reform}

But the Declaration of Principles of the American Prison Congress in 1870 suggests a real transition period, where the notion of "reform through punishment" is in its turn giving way to notions of "rehabilitation by methods independent of punishment." The concept of rehabilitation is beginning to appear, at least by implication, though the possible methods other than punishment are not indicated or, if indicated, are mere incidentals of the punitive process. Thus the Declaration says:

"II. The treatment of criminals by society is for the protection of society. But since such treatment is directed to the criminal, rather than to the crime, its great object should be his moral regeneration. Hence the supreme aim of prison discipline is the reformation of criminals, not the infliction of vindictive suffering."

Thus far there is nothing new in the Declaration; it is preceded by volumes of utterance to the same purport. But it continues:

"III. The progressive classification of prisoners, based on character and worked on some well-adjusted mark system, tion in such provisions as articles 91 and 92 , to the effect that an offender who was drunk "from an accidental event or from force majeure," at the time of the offense shall have his punishment reduced if his drunkenness was "such as largely to diminish responsibility, but without excluding it;" while "if the drunkenness was pre-ordained for the purpose of committing an offense, or for providing an excuse, the punishment shall be increased." Penal Code of the Kingdom of Italy, translated from the Italian, His Majesty's Stationery Office, London (193I). 
should be established in all prisons above the common jail.

“V. The prisoner's destiny should be placed, measurably, in his own hands; he must be put into circumstances where he will be able, through his own exertions, to continually better his own condition.

This seems truly the "rehabilitative," rather than the "punitive" notion. As to segregation so long as dangerousness continues, rather than for a merely punitive period, the Declaration asserts:

"VIII. Peremptory sentences ought to be replaced by those of indeterminate length. Sentences limited only by satisfactory proof of reformation should be substituted for those measured by mere lapse of time."

Since the date of that Declaration of Principles, one finds additional and even more emphatic advocacy of change in the treatment of the known offender. This new philosophy amounts to a definite repudiation of the "penal" system as such, and urges the substitution of truly "corrective" methods suited to the necessities of the individual.

Some of this advocacy is implicit, rather than precisely expressed. But it is an absolutely ineluctable implication from the causes of crime which the particular writers assume to exist-causes which obviously could not be either eliminated or even counteracted by mere imposition of punishment.

One reads, for example, that "Criminal biology, as defined in the basic text (of Adolph Lenz) is 'the systematic study of the personality of the offender and of his offense as an individual experience.' For the study of personality from the point of view of criminal biology, the hereditary background of the offender is of primary importance. Accordingly, the objective of research in criminal biology has been to demonstrate the significance of the hereditary factor in the formation of criminal personality. . . . The psychiatrist, Friedrich 
Stumpfl, after study of a number of repeaters, arrived at the conclusion that crime is the product of certain character traits which are inherited. The validity of his conclusion is greatly impaired by the unscientific manner in which the data have been gathered, which is quite typical for the investigations of family histories taken by criminal biologists."

Regardless of whether or not this biological theory is sound, it has indeed been advocated by many criminologists from Lombroso through Kretschmer, with his physiologic criminal types of asthenic, athletic, and pyknic, ${ }^{36}$ and Hooton with his notions of height and weight as related to criminal tendencies. ${ }^{37}$ If there be even a modicum of truth in these assumptions of the basis of criminality, it must follow that the product of hereditary or of physical characteristics cannot be treated by punishment alone with satisfactory results in the protection of public safety and security. The mere assertion of the biological basis of crime amounts, therefore, to a commensurate assertion that treatment other than mere punishment is an essential to public protection.

The same thing may be said, of course, concerning many other theories of the cause of criminality. Morris Ploscowe, although he does not specifically express his own ideas of what should be the proper treatment of known criminals, points out numerous causal factors which obviously cannot be eliminated by punishment alone, but must necessarily be dealt with by other methods suitable to the individual. $\mathrm{He}$ says, for example:

"Nevertheless tuberculosis, heart disease, hernia, defects of vision, etc., may be found in individual cases to be causes of delinquency in so far as they prevent or tend to prevent the sufferer from earning a living, just as Goring suggested that

${ }^{36}$ Ernst Kretschmer, Physique and Character, translated from the German by W. J. H. Sprott, London (1936).

${ }^{37}$ E. A. Hooton, Crime and the Man (1939). 
inferior physique may be at the bottom of man's criminal behavior by handicapping him in legitimate occupations."

And again, "The endocrinologists claim that the functioning of the glandular system profoundly affects physical development. As Berman states, 'More and more we are forced to realize that the general form and external appearance of the human body depends to a large extent upon the functioning, during the early developmental period, of the endocrine glands. Our structure, the kinds of face we have, the length of our arms and legs, the shape of the pelvis, the color and consistency of the integument, the quantity and regional location of our subcutaneous fat, the amount and distribution of the hair on our bodies, the tonicity of our muscles, the sound of the voice and the size of the larynx, the emotions to which our exterior gives expression, all are to a certain extent conditioned by the productivity of our glands of internal secretion.'

"But not only is the claim made that the glands of internal secretion determine the physical features of the individual. It is also asserted that they are the real governors and arbiters of instincts and dispositions, emotions and reactions, character and temperament. Just as certain patterns are formed in the body by a particular arrangement of the ductless glands, so the mind also receives its pattern from the same source. A man's nature is then chemically his endocrine nature."

Ploscowe discusses at considerable length and with several references, these theories of the endocrinologists. "The science of endocrinology is still too young, and there is still too much disagreement about its data to allow definite conclusions. But this type of research contains interesting possibilities. If it establishes fundamental biochemical mechanisms at the basis of human conduct, the finding cannot fail to be of importance in an understanding of criminal behavior, which is but one form of human behavior." ${ }^{38}$

He might have added-what is a logically inescapable conclusion - that if the biochemical mechanism is established as

${ }^{38}$ Morris Ploscowe, "Some Causative Factors in Criminality," 3 U. S. Commission on Law Observance, Causes of Crime, Part I ( I 93I) pp. 27 ff., 36. 
the basis of human conduct, the most effective form of crime preventive treatment should be one directed toward alteration of that mechanism.

These clear implications that treatments more specific, more varied, and more individualized than is possible under any penal procedure are necessary for the safety of society, find explicit assertion by Healy and Bronner:

"Only through picturing individuals as they are, made what they are by a combination of external causes and their own natures, and partly by the treatment that has been given them, can adequate impetus be given to a demand for the application of scientific method in this field.

"Without scientific practice the situation that embraces the needs of the individual and the needs of society is not met when he is handled as an offender, and very often indeed he turns and rends society. This result as reaction can be read between the lines of many a criminal's life history. Again, the first requirement of self-protection is that society make every attempt to understand the offender, to deal with him in ways that do not deteriorate him, but rather that build up in him a better mental attitude, by methods that make for him a fair opportunity after release from institutional life.

"Nor can a plan be safely founded except upon recognition of the large variety and complexity of causes that any careful student of cases of delinquency and criminality can demonstrate. The theories earlier set forth voluminously by continental writers and the narrow, one-piece explanations of some American and English theorists must all be discarded for a larger vision. We must perceive the individual and his environment reacting back and forth on each other, each being changed as each is reacted on.

"We can easily enumerate a grist of criminological theories: possession by the devil; economic and sociological theories of causation; theories accounting for crime by imitation, degeneracy, heredity; crime as a disease; the somewhat later absurd attempts to account for a very large share of misconduct as manifestations essentially of epilepsy, feeblemindedness, injury of a hypothetical 'moral brain center' immigration, 
physical inferiorities and irritative conditions, such as imperfect vision or focal infections from abscessed teeth, psychopathic inferiority, innately defective emotional make-up, midbrain lesions, poverty, the unclear conception of dementia precox, inadequate personality, neurotic compensations for inferiority. These are enumerated to show, not that there is no truth at all in them, but rather that the very multiplicity of theories proves the danger of setting about any program that is based upon the idea that all or a large share of delinquency and crime is attributable to any one cause.

"The same warning may be given against following any such simply founded theory of treatment. Any expectation of accomplishing all or nearly all in the way of effective treatment by some particular plan of using force, punishment, kindness, religious appeal, medical care, or by any set form of reformation, is doomed to disappointment. The varieties of human beings and the varieties of causes of delinquency are too many to be met by a unitary conception of what it is possible to do in the therapy of delinquency and crime.

"In general terms it may be insisted that a hard-headed, entirely practicable, but scientific, social and legal plan, farseeing and far-reaching, is the great primary necessity." 39

This express recognition of the need for treatment of known criminals by methods other than merely punitive is not confined to the philosophic cloisters.

"Keenly alive to the fact that 97 per cent of those who go to prison return to society, modern prison officials see the necessity of making the period of incarceration an opportunity to prepare each prisoner for the day when his confinement is over. This new point of view endows the prison with the function of carrying out careful, individualized study, treatment, and training of offenders, using the knowledge and techniques of medicine, psychiatry, psychology, education, vocational guidance and training, religious instruction, recreation, and every other discipline which contributes to the understanding and management of people. . . . Your committee finds

${ }^{39}$ William Healy and Augusta Bronner, Delinquents and Criminals (1926) p. $227 \mathrm{ff}$. 
little dissent from this point of view among the students and practitioners of penal administration, but it does find widespread departures in practice." ${ }^{40}$

A practical assertion of this more modern notion of crime prevention appears in the report of the Director of the Federal Bureau of Prisons for 1939 in which he says, "All of the new institutions are, we believe, planned in accordance with the modern concept of the penal institution as an instrumentality for rehabilitating and reforming the prisoner. Rather than expending our appropriation on expensive tool-proof steel, high walls, and elaborate locking devices, we have sought to provide the maximum number of housing units supplemented by adequate school, shop and training facilities." 41

Thus we find, as a relatively recent development, both from the ivory tower and from the fields of practice, a vigorous advocacy that instead of mere punishment as a preventive of crime there be substituted a variety of treatments calculated to eliminate those conditions within the individual which caused him to offend and may cause him to offend again.

\section{c. Theories of Contimued Segregation}

That other ideal, the proposition that when a known offender cannot be fitted for safe return to freedom in society he should be segregated, not merely for a maximum period, but really indefinitely-for life if necessary-has found far less clear advocacy, though, as will be seen, it has found some actual adoption. The recognition of its necessity, however, is

${ }^{40}$ American Bar Association, Section of Criminal Law, Report of Committee on Sentencing, Probation, Prisons and Parole, Sept. 1940, p. 20.

${ }^{41}$ An unusual judicial recognition of what ought to be the purpose of treatment of convicted criminals is expressed by Justice Hammer of the New York supreme court, in People ex rel. Montana v. McGee, I6 N. Y. S. (2d) I62 (1939). "It is the object of the Parole Law to afford every convicted person subjected thereto the privilege and opportunity to benefit by the disciplinary, correctional and reformatory purposes of the institution of incarceration. ... The object is moral reformation of the prisoner, rather than punishment." 
cogently exemplified, even if oddly so, in the action of a sentencing judge who put an eighteen-year-old boy, charged with eleven robberies in two years, on probation for fifty-five years -five years for each offense-on the theory that he needed "probation for life, and society needs protection from you." ${ }^{2}$

\section{PRESERVATION OF PUNITIVE VALUES}

This growing awareness that other treatment of convicted criminals may protect society against repeated offense more effectively than mere punishment protects it does not preclude recognition that whatever is done to the criminal himself may have an effect on the conduct of others. To what extent the punishment of one restrains another's tendencies toward crime we do not know. That it does have some effect and is thereby a protection of the social safety we assume. Hesitancy in yielding whatever of such good there may be in the punitive system quite understandably begets a hesitancy in discarding the punishment of convicted criminals and substituting other methods of treatment. There is fear lest in grasping at the shadow of a hoped-for diminution of repeated criminality we may lose the reality of an assumed restraint upon original crime.

Whether or not the failure of punishment to prevent repetition of crime is so complete, and its restraint of original crime so slight, that the latter might well be foregone in hope of improving the former, is perhaps open to argument. And this discussion aims at exposition rather than argument. The present writer perforce concedes, therefore, the validity of an assumption that punitive treatment of convicted criminals does restrain criminality by others who witness that punishment, and that this restraint should not be sacrificed to the desire

${ }^{42}$ I 8 Probation 138 (June, 1940) published by the National Probation Association. 
for greater effect upon the persons so treated. But it does not follow that the adoption of segregative and rehabilitative treatment of convicted persons, instead of punishment, would in fact lessen the desirable effect upon others.

To the extent that fear of punitive imprisonment is a factor in law-abiding conduct, the fear of segregative imprisonment will be equally potent, so those who advocate segregation during the whole period of dangerousness assume. The confinement will be as undesirable, as sedulously avoided, regardless of why it is enforced; its very indefiniteness of duration should make it more potent a threat than the prospect of a known duration. If, on the other hand, one adopts the theory that the effect of punishment lies less in the physical fear created than in unwillingness to incur the public reprobation evinced by punishment, then the stigmatization of a wrongdoer as unfit to associate with his fellows until he has been reformed in character is presumed to be quite as appalling as the condemnation by punishment. So, too, that crystallization of popular conceptions of right and wrong, that inducement of subconscious abhorrence of evil conduct and choice of good which Stephen and Aschaffenburg postulate as the proper objective of punishment ${ }^{43}$ will result in equal force from the conviction of an offender, regardless of whether his treatment thereafter be punishment or enforced rehabilitation for social existence.

The once conventional idea of preventing crime by threat of the most appallingly horrendous consequences long ago fell into obsolescence. Mutilation, deportation, flogging, the horrors of Botany Bay and Devil's Island, proved their own futility. One after the other they passed into disuse, and hope for the effectiveness of punitive treatment came to rest upon confinement and amercement. Now, say advocates of a different treatment, all the possible expectancies of fine and im-

${ }^{43} O p$. cit. supra notes 16 and 17, p. 17. 
prisonment as influences upon the conduct of others than the victims will spring in even greater measure from a judgment of unfitness for social freedom, with its consequent possibilities of confinement and enforced rehabilitation.

In this way, then, the newer philosophy, though it repudiates the effectiveness of mere punishment as a preventive of repeated crime and advocates other means to that end, maintains also that none of the assumed effectiveness of punishment as a socially desirable influence upon the conduct of others would be lost by the change. 


\section{Chapter IV}

\section{Legislative Authorization of Non-punitive Treatments}

\section{AVOIDANCE OF CHARACTER-DESTRUCTIVE CONTACTS}

$\mathrm{N}$ EW ideas of preventive treatment for convicted criminals would hardly be translated into actual practices without legislative sanction. To the extent that existing legislation does permit departure from the traditional procedures and allows the employment of substitute methods, some change from the merely punitive methods may in fact develop without specific legislative direction. But without such permission the change could not develop. Nor would it be likely to develop in the absence of something more than mere permission, some affirmative authorization. Assuming, then, that the newer philosophy of preventive treatment has attained such standing that the wish to put it into practice is a dynamic force, the extent to which existing statutes authorize, or at least permit, such practices becomes a pertinent and important inquiry.

The improvements which the new philosophy would make in preventive treatment, the departures from the traditional merely punitive system, are in four major fields.

I. It would emphasize the avoidance of characterdeteriorative contacts and conditions during the period of treatment.

2. It would provide for segregation from society during the whole period of an individual's known dangerousness, regardless of the amount of "punishment" he could be said to "deserve."

3. It would utilize all the possibilities of training in trade 
skills, of education, medicine, surgery, and any other means whereby each individual's capacity, as well as his will, to lead a law-abiding existence might be developed and strengthened.

4. It would render to convicted criminals an affirmative and active assistance in their efforts to abstain from further crime.

The question, then, is to what extent existing legislation does permit, authorize, or possibly direct the practical utilization of any of such procedures.

\section{a. Release Without Imprisonment}

Statutes now generally depart from a strictly punitive theory to the extent of not absolutely requiring punishment after conviction, either by imprisonment or by fine.

In almost every state one finds legislation which permits the trial judge to suspend imposition of sentence, or the execution of sentence, and to permit a convict his liberty upon various conditions. The Colorado statute is typical in its provision that when a judge is satisfied that "the ends of justice and the best interests of the public, as well as of the defendant, will be subserved thereby," he may suspend imposition or execution of any sentence for any crime except first or second degree murder, unless the defendant has previously been convicted of felony. ${ }^{43 a}$

The details of the statutes vary considerably. Some require that the defendant be placed on probation and committed to the supervision of a probation officer. Others permit probation, but do not require it. Some make exception of numerous specific crimes for which punitive sentence cannot be suspended; others permit a wide discretion in the judge with but few specific limitations. But, subject to such variation, recog-

${ }^{43 a}$ Colorado, 4 Stats. Ann. (1935) ch. 140, sec. I. 
nition of the danger to society from an insistence upon actual imprisonment in every case is well established and, generally speaking, trial judges have been given ample discretionary power to avoid it. ${ }^{44}$

\section{b. Release After Imprisonment}

In the event that a judge does not exercise his discretionary power to keep a convict out of prison, but commits him thereto, a certain amount of possibly deleterious contact and association, or possible character-degradation from other causes, necessarily must result. But even in such case the existing law makes considerable definite provision for termination of such influences within a relatively short time.

To say that the originating purpose of these "parole" laws is prevention of further destructive influence upon the prisoner would be an unduly optimistic interpretation of legislative motive. The possibility of release from imprisonment through operation of the "pardoning power" appears to have sprung instead from the necessity of a method of rectifying mistakes, or otherwise dealing promptly and justly with what might be considered more or less infrequent and emergency situations. The power of established state parole boards to release on parole does not show indication in its origin of much thought concerning the hurtful effect of prison life and contacts upon particular individuals. On the contrary, everything points to its origin in the release of persons who are no longer dangerous and no longer need to be incarcerated. Perhaps also there is some notion of its wisdom as a reward for exemplary behavior while in prison; a supplement, as it were, to the generally established "good conduct" deductions from length of sentence. And certainly the power of release on parole, whatever its original purpose, has not infrequently been utilized as a

44 The various state statutes are noted in Appendix A, p. 95. 
method of making room in the penitentiary for newcomers by freeing those whom the parole board believes "have been punished enough."

Nevertheless, whatever may be the theory or purpose behind the power, the fact remains that in every state some agency is invested by existing law with power to release from prison any person whose fitness for social existence is especially likely to be adversely affected thereby and whose release will not be socially harmful. In every state, either by constitution or statute, a pardoning power has been created which may operate at any time and, with variant exceptions concerning such offenses as treason or murder, in respect to any convict. And this power may be exercised by setting up conditions to which the person pardoned must conform his conduct. It thus amounts in legal possibility, though by no means necessarily so in actual practice, to a power of release on parole exercisable at any time after conviction, regardless of the term of sentence or the length of imprisonment actually suffered.

In addition to this "pardoning power" nearly every state has by legislation vested authority in some agency to "parole" prisoners, as distinct from "pardoning" them, whenever certain conditions have been fulfilled. These are the so-called "parole" laws. The scope of this power varies considerably in different states and, as already pointed out, its primary purpose is not the prevention of socially harmful character degradation through prison experiences. Nevertheless, it is a legally existing power which could be utilized to that end, if it could be utilized promptly. In general, however, it can hardly be accepted as a provision suitable to the particular end under discussion-preventing the creation of criminal tendencies through the adverse effects of prison experience-because the necessary delays before it can be put into operation would ordinarily make its use too late. 
In a few states the release from confinement may be made at any time after sentence, without delay. In these states it might well be used for the particular purpose of protecting society by forestalling character-destruction in particular cases where trial judges have failed to exercise their own powers in that respect. In other words, the power of parole, under the existing law of these states, could be utilized as a supplement to the judicial power of probation. To what extent it is so used no data are available, but the idea that it ought to be so used has been so seldom, if ever, explicitly asserted that one may doubt its use to that end at all. And even in those states where no minimum period of imprisonment is required before release, the established rules of some releasing boards prevent a promptness of action requisite to the particular purpose. $^{45}$

\section{c. Separation of Different Types of Prisoners}

The evil effect of prison associations upon the individual might to some extent be minimized by limiting the type of his possible contacts, through careful classification of prisoners into several institutions or divisions of an institution. In this way youth might be segregated from maturity, the novice from experience, relative innocence from indurated viciousness. There are now statutes in many states authorizing a certain amount of "classification" of convicts. Possibly some of them are broad enough in their terms to permit a fairly varied classification based on the needs of numerous groups of different individual types.

Thus, in addition to a psychiatric division, the legislation of Illinois now provides that the Department of Public Safety may determine such divisions of the penitentiary system "as it may deem expedient in light of considerations relating to the age and character of the inmates, the necessity of preserv-

45 These statutes are noted in Appendix B, p. 106. 
ing first offenders from contact with recidivists and such other criteria of classification as may be dictated by penological science. . . . "The Department has "full power to transfer prisoners from one division to another as often as the nature of the case or the exigencies of administration may require." 46

Such a provision, written in general terms, seems all that might be needed, so far as legislation rather than actual facilities is concerned, for the utmost effort in preventing character-degradation or intensification of criminal tendencies through prison life. So, too, the Louisiana statute, though of a different type and somewhat vaguer in its wording, is broad enough in its language to permit all such necessary classification. It provides simply that the board of control may make rules "for the grading and classifying of the convicts according to the most modern and enlightened system of reformation. . . . ${ }^{47}$

The great majority of the classification statutes, however, are limited to a differentiation between youth and maturity. Thus the Alabama statute merely provides that "convicts under eighteen years of age shall, at the discretion of the director, be separated and worked apart . . . keeping in view their moral and intellectual improvement". ${ }^{48}$

Still other statutes are obviously drafted in terms only of actually existing facilities and do not contemplate anything more than a proper use thereof, without regard to any possibilities of classification for protective purposes in general. Thus the Iowa statute merely gives the prison board of control power to transfer prisoners from penitentiary to reformatory and from reformatory to penitentiary. ${ }^{49}$ And the Con-

${ }^{46}$ Illinois Rev. Stats. (1935) ch. 108, secs. 106, 1 10 (Jones Ann. Stats. 99.089, 99.093).

${ }_{47}$ Louisiana Code of Crim. Proc. (1932) art. I432.

48 Alabama Code (1940) tit. 45 , sec. 38 .

49 Iowa Code (1939) secs. 3732, 3751. 
necticut law provides that any prisoner under thirty years of age and having less than ten years of his minimum sentence to serve and who, "in the opinion of the board of directors of the prison, would be benefited by the training provided at the Connecticut Reformatory, may be transferred" thereto. If he proves not susceptible to reformatory methods he may be returned to prison. ${ }^{50}$

Speaking generally, it must be said that unless a convict is kept out of prison by action of the trial judge, or is promptly released therefrom by action of a parole board, the danger of character-degradation in particular cases is not avoidable. There are few existing facilities for the necessary separation of various types and, with the exception of such statutes as those of Illinois and Louisiana, existing legislation does not expressly authorize penal authorities to establish satisfactory group divisions within existing institutions. ${ }^{51}$

\section{SEGREGATION DURING THE WHOLE PERIOD OF DANGEROUSNESS}

So far as relates to protection of the public safety by continued segregation, or at least continued supervision, during the period of known dangerousness, little that is directed specifically to that end appears upon the statute books.

Whenever an individual is recognized as being "insane" there is of course widespread and detailed legislation calculated to protect society against him. When the necessity can be shown to exist, there is no dearth of authority for keeping such a one indefinitely segregated. The only problem arises in respect to individuals who are not "insane" in the significance traditionally given to that term in the interpretation of statutes concerning it. Where the line is to be drawn between

${ }^{50}$ Connecticut Gen. Stats. (I930) sec. 1982.

51 The various statutes are noted in Appendix C, p. $1 \times 3$. 
"insanity" which subjects an individual to confinement, and conduct abnormalities which make him socially dangerous but leave him "sane" is quite unguessable. Mr. Horace B. English; in his Student's Dictionary of Psychological Terms (1928) gives this definition: "Insane, Insanity. Terms of such vague psychological meaning that their only application now lies in the legal sphere; it is any mental disorder of the sort which brings a person under special legal custody and immunities." But even lawyers cannot be said to have clearly delimited the particular mental condition for which indefinite confinement is authorized by law. Suffice it, then, to assume that an individual may be recognized as socially dangerous, in the sense of showing a propensity for crime not observable in the great mass of the population, and yet not be subject to segregation from society under the laws relating to insane persons. The question is, to what extent do other statutes permit indefinite segregation of such a person during the period of known dangerousness?

\section{a. Repetitious Offender Statutes}

A number of states have enacted legislation providing unusually long terms of imprisonment, even unto confinement for life, of persons who have been three or four successive times convicted of major crime. It is true that confinement for a long period of time does in fact protect the public from any continuing dangerousness on the part of the person confined, and to this extent the so-called third and fourth offender laws do operate in a protective as well as a punitive sense. Nevertheless, the text of such statutes indicates that their primary purpose is the prevention of repeated crime through threat of increased punishment therefor, rather than a serious effort to distinguish presumably incorrigible persons from those not so likely to offend repeatedly, and to keep the 
former segregated from society because of their known incorrigibility. These laws make no pretense of application to persons who are known to be dangerous, but who have not yet actually been convicted of the permitted number of major offenses. On the other hand, they do apply to every person who has been so convicted, without provision for investigation of his actual dangerousness.

The Michigan statute is characteristic of this type. It provides that "A person who, after having been convicted within this state of a felony . . . commits any felony within this state, is punishable upon conviction as follows: If the subsequent felony is such that, upon a first conviction the offender would be punishable by imprisonment for any term less than his natural life, then such person must be sentenced to imprisonment for a term not less than one-half of the longest term nor more than one and one-half times the longest term prescribed for a first conviction of such offense. . . . "For a third conviction he must be sentenced to not less than the longest term nor more than twice the longest term provided for a first conviction. A fourth conviction must result in imprisonment for life if the first offense could have been punished by five years' imprisonment. ${ }^{53}$

${ }_{53}$ Michigan, 3 Comp. Laws (1929) sec, 17338 ff. (Michigan Stats. Ann. $\$ 28.1082)$. The attitude of many courts toward these statutes also indicates that their real purpose is more drastic punishment, rather than segregation because of dangerousness. Thus, the Indiana Supreme Court in Kelley v. State, 204 Ind. $6 \mathrm{I}_{2}$, 185 N. E. 453 (1932) in rejecting a contention that the statute was "not based on principles of reformation" but was "an ex post facto law authorizing punishment for crimes committed prior to the passage of the act," said, "The statute does not impose an additional penalty on crimes for which the defendant had already been convicted. It simply imposes a heavier penalty for the commission of a felony by one who has been previously twice convicted. . . . The punishment is more severe because the defendant is an habitual criminal."

So, too, Judge Crane in People v. Gowasky, 244 N. Y. 45 I, I 55 N. E. 737, 58 A. L. R. 9 (1927), "The punishment for the second offense is increased because of his apparent persistence in the perpetration of crime and his indifference to the laws which keep society together; he needs to be restrained by severer penalties than if it were his first offense."

But while such statements are characteristic of judicial opinions where the 
The California statute ${ }^{54}$ is at least a trifle more suggestive of long imprisonment as a segregative measure rather than as a merely punitive one, in its provision that "in exceptional cases" the trial court, acting within sixty days of the commencement of the imprisonment, may render judgment that 'the particular individual is not in fact a "habitual criminal" and therefore need not be subjected to the long imprisonment. ${ }^{55}$

\section{b. Indeterminate Sentence Statutes}

The so-called "indeterminate sentence" laws of many states are obviously measures designed to regulate the length of segregation with some relation to the necessity for segregation. They are not truly "indeterminate" segregation laws, because the maximum period of segregation must be in fact specifically stated in the sentence, or is fixed by the statute itself. When the maximum period has elapsed the prisoner must be released regardless of his unfitness for social freedom. On the other hand, he cannot as a rule be released before a minimum period of imprisonment has passed, however clear may be his fitness for freedom. But between these limits it may fairly be said that, theoretically at least, a convict's release or continued confinement is made to depend upon the compatibility of his

constitutionality of the statutes has been questioned, one finds in an occasional opinion some suggestion, albeit confused with the punitive notion, of a more primarily segregative purpose. The California Supreme Court, In re Rosencrantz, 205 Cal. 534, 27I Pac. 902 (1928), after declaring that life imprisonment for a repeated felony was not so disproportionately harsh a penalty as to shock the moral sense and hence did not constitute cruel and unusual punishment, added, "When a person has proven himself immune to the ordinary modes of punishment, then it becomes the duty of government to seek some other method to curb his criminal propensities that he might not continue to further inflict himself upon law-abiding members of society. This, we think, may be done even to the extent of depriving him permanently of his liberty."

${ }^{54}$ California Penal Code (x 941) sec. 644.

${ }^{55}$ Because these statutes are not essentially provisions for segregation during dangerousness, but merely establish high maximum penalties, their collection in the appendix is thought unnecessary. 


\section{8}

\section{THE PREVENTION OF REPEATED CRIME}

return to social freedom with social safety. And inasmuch as an extremely high proportion of convicts sentenced under such laws are released before the maximum authorized period of segregation has elapsed, it seems reasonable to say that these statutes, to the limited extent of their existence, provide a possible period of segregation sufficiently long for satisfactory public protection in most cases.

There is a serious insufficiency in this type of legislation, however, in that it does require eventual release of every convict no matter how incompatible with public safety that release may be. Moreover, for many kinds of wrongdoing in respect to which a high probability of repetition is easily demonstrable, the maximum term of authorized imprisonment is relatively short.

Hence, while the indeterminate sentence laws, if wisely administered, may suffice to keep a certain type of criminal segregated from society so long as his dangerousness to public safety continues, they are quite inadequate to the safety problem as a whole.

\section{c. Statutes Permitting Segregation "Until Cured"}

This lack has been perceived in occasional states and rectified to some extent by truly indefinite segregation provisions for certain specific types of probably repetitious offenders. In these statutes the term of confinement makes no pretense of being related to the heinousness of the crime committed, but is expressly declared to endure for the whole time that the offender's dangerousness continues. At present such statutes represent only a tentative beginning toward the ideal of public protection through segregation, rather than through punishment. They are few in number and they apply only to a narrow range of dangerous types of person. In content, though all of them are of limited application, their individual limitations 
differ materially. Some, like that of Illinois, apply only to "sex offenders"; others, like the Massachusetts statute, to "mentally defective" or "habitually delinquent" persons charged with any sort of crime, who are not insane or feebleminded. ${ }^{56}$

Some analogy, albeit a remote one, may exist between this problem of segregation of persons who are socially dangerous because of a tendency to repeated crime and the confinement of persons who are dangerous because of a tendency toward intoxication. Several states authorize segregation of inebriates, under a variety of circumstances and for a variety of periods, and some statutes put the segregation squarely upon a basis of dangerousness to the public. ${ }^{57}$

Taken all together, however, these various statutes do no more than touch the edges of the difficulty. "Insane" persons

${ }^{56}$ A list of such statutes will be found in Appendix D, p. 121.

An interesting type of statutory confinement because of dangerousness to the public-but a matter of insufficient significance to warrant thorough search for other instances-is the Connecticut statute (Gen. Stats. (1930) sec. 1904) which provides that an inmate of any penal or charitable institution whose discharge would be dangerous to public health because of venereal disease must be detained "until he may be discharged . . . without danger to the public health."

But compare section 2374 of the same statute to the effect that if a person confined in a jail or penal institution for ten days or more is found to be suffering from any malignant, infectious or contagious disease, he shall be treated therefor and if he is not cured during the term of his confinement, the local health authorities shall be notified.

In Alabama the statute, Acts (1939) no. 228, p. 369, provides only that if a prisoner is discharged while still subject to an infectious venereal disease, written notice of the fact must be given to the health officer of the county to which he is returned.

Somewhat similar statutes, requiring continued isolation, or an obligation to report for treatment, can be found in Nebraska, Comp. Stats. (I929) sec. 83-r 403; New Hampshire, Rev. Laws (1942) ch. 449, sec. I 8 ; North Carolina, Code Ann. (1935) sec. 7r94; Ohio, Throckmorton's Code (r940) sec. 13031-17; Oregon, 6 Comp. Laws Ann. (1940) sec. 99-719; Rhode Island, Laws (1938) ch. 55, sec. 28; South Carolina, I Code (1932) sec. 1496, Acts (1 941 ) no. 76, sec. I; Utah, Code Ann. (1943) sec. 35-4-40; Virginia, I Code (1936) sec. 4548f; Washington, 7 Rev. Stats. (1932) sec. 6102; Wyoming, Rev. Stats. (1931) sec. 103-236.

${ }^{57} \mathrm{~A}$ number of characteristic statutes, though not a complete list, will be found in Appendix E, p. 129. 
may be confined for the sake of public safety. Persons dangerous to health may be confined. But men who have been punished as much as their committed crimes deserve cannot, under existing laws, be confined merely because it is evident that if released they will offend again.

\section{REHABILITATION}

For the rehabilitation of persons while in confinement there is ample statutory authority - which does not mean ample facilities-for some procedures, and virtually no authoritynor facilities-for other procedures.

\section{a. Training in Trade Skills}

Possibly the most important type of rehabilitative activity -important because of the number of individuals to whose needs it would be suited-is training in trade skills. If it be true, as many criminologists believe, that poverty is a potent cause of crime and that poverty is often the result of inability, through lack of skill, to compete successfully in the job of self-support, it follows that proper training in trade skills should be an effective method of crime prevention in many cases. Certainly the development of education in trade skills is a notable feature of the modern attitude toward underprivileged groups generally. If it is valuable for persons who have not yet committed crime, it must be equally, valuable as a means of public protection against persons whose repetition of crime it is desirable to prevent. Statutes directly or indirectly relating to the use of such training for convicted criminals are relatively numerous, but variant.

The fact that "hard labor," or "labor," is set up as one of the consequences of conviction signifies nothing concerning 
rehabilitative possibilities. Originally, and still persistingly, the provision was merely a part of the penalty-often a mere expression of the feeling that life in jail should not be made easy for persons being punished by confinement. For this purpose it was not important what form the labor took, so long as it kept the laborer at work.

The more recent shift from hard labor as a punitive measure, to labor as a means of keeping prisoners psychologically healthy and of keeping idle hands from employment by the devil, is still not a rehabilitative notion. It insists on labor only for the sake of keeping prisoners occupied, and little emphasis is laid upon the type of occupation furnished. ${ }^{58}$

Rehabilitative labor, on the other hand, must be primarily educational rather than merely time-consuming. It must be utilized to better a prisoner's ability to compete in honest selfsupporting activity after his release.

But though one finds in the statutes ample authority for prison administrators to provide work for prison inmates, the idea of utilizing that work as a means of training the prisoners in ability for self-support appears only infrequently in the legislation itself. Nevertheless, there are in fact numerous statutes which would at least permit prison authorities to establish in their institutions real courses of training designed to develop and increase the competency of prisoners to earn an honest living after release.

${ }^{58}$ It may be of some significance as evidence that the rehabilitative idea is not yet clearly grasped, that at the International Penal and Penitentiary Congress, in Berlin, 1935, discussion of the problem of work by inmates in penal institutions confined itself, implicitly, to consideration of work as a therapeutic occupation, with no practical consideration of work as a rehabilitative measure. The resultant resolution was to the effect that "prison work playing an important part in the execution of punishment and lack of work having the most pernicious effect on the prisoners' character and outlook, sufficient work must be provided for them" by employment on public works, by replacement of machine work by hand labor, and by division of available work hours among a greater number of prisoners. 


\section{b. Trade Training-Market for Products}

Before such statutes are discussed, however, it is necessary to give some attention to other statutes which, if only by indirection, adversely or beneficially affect the practical possibilities of such training. For instance, if training in trade skills is to be utilized to any great extent for the thousands of prisoners whose criminal activities may presumably be reduced by that means, mere practicality requires that there be a reasonable market for the products of that training. Obviously, if the products cannot be sold or otherwise usefully disposed of, it is scarcely conceivable that prison administrators will be either in a frame of mind to develop training courses vigorously, or in a financial position to do so.

Opposition to sale on the open market has come from various interests and is based upon various predicates. In 1934 a committee was appointed under the National Recovery Administration to "investigate the effects of competition between the products of prison labor and sheltered work shops on the one hand and of the cotton garment industry on the other." This committee listened to numerous arguments and protests and reported that:

"From the Cotton Garment Industry and from Organized Labor arises the most vigorous and determined opposition to the present status. . . . It claims that a continuance of prison-made goods upon the open market will destroy the cotton garment code and push the industry back into the miserable sweat-shop conditions from which it is emerging. . . Asked whether they would prefer the untrammelled competition of unregulated prison industry to further efforts to coordinate that industry with free-labor industry under the Compact, the representatives of the garment trade answered emphatically 'Yes.' They profess absolute disdain of the possibility of effective control of prison manufacture; some of their spokesmen charge every agency of prison management 
with direct bad faith. They claim that unless the competition of prison labor is absolutely eliminated, the entire industry will be ruined and its 165,000 employees will be thrown out of employment."

Previous to this investigation there had been set up a "Prison Labor Compact" by which contractors who used prison labor were required to pay that labor at rates based upon the prevailing rate of pay for free labor, thus, presumably, eliminating the influence of "cheap labor" upon the free standard of living.

The committee's own comment upon this objection to sale of prison-made goods is:

"The testimony given by this group is important out of all proportion to its accuracy in detail. A state of mind, whether based on fact, fear, or fancy, is something that must be reckoned with. These manufacturers are determined that competing prison labor must go. . . . Right or wrong, they are prepared to fight on this issue to the bitter end. In this fight they are working hand in hand with labor, and they have the support of large sections of the distributing trade and the consuming public. Such women's organizations as the Federation of Women's Clubs, the Consumers' League and others, have joined the manufacturers and labor in the dissemination' of the thought that goods made in a prison are essentially wicked goods that must not enter into commerce." 59

As a result of such opposition, statutes in a large number of states prohibit the sale or other disposition of convict-made goods upon the general market. ${ }^{60}$

To the extent that these statutes are unmodified by other legislation, they amount to a serious limitation upon any employment of prisoners, even for purposes of mental health and prison orderliness. As a practical matter they would ren-

${ }^{59}$ See United States National Recovery Administration, Report of Committee on Competition of Products of Cotton Garment Industry with Products of Prison Labor as directed by Executive Order No. I $18-1935$ of October 12, I 934 , by Jos. N. Ulman, Frank Tannenbaum, W. Jett Lauck, pp. 1, 4, 5 .

${ }_{60}$ Statutes on this point will be found in Appendix F, p. I 34. 
der rehabilitative trade training, which requires a wide diversity of marketable products, virtually impossible.

But in many states these statutes prohibiting sale on the open market do not stand alone, or without some exceptions. Sometimes by implication, often by express statement, the legislation provides a market for the prison-made products other than that of free public sale. Thus the Arizona statute, though it flatly declares that no products of prison labor "shall be sold or exchanged on the open market within the state of Arizona," says further that "sale upon the open market . . . shall not include sales or exchanges between any penal or charitable institutions maintained wholly by the state of Arizona or any of its political subdivisions for use in any such institutions or by the wards thereof." ${ }^{61}$

Some statutes merely leave open to prison products the possible market of other state institutions, and let the actual availability of that market depend upon the voluntary cooperation of the other institutional administrators. ${ }^{62}$

Still other statutes go much further in providing a market and specifically provide, as in Arkansas, that it is the duty of state institutions to buy from the prisons "as far as possible," or that of Indiana to the effect that "the state, its institutions, except those which produce similar articles, and the political divisions of the state using such articles as may be produced - . . shall be required to purchase such articles at a price fixed by the board of classification of industries." ${ }^{63}$

Wherever sale of goods on the general market is not hampered by legislation, and in states where such sale is prohibited but a compensatory market is furnished through purchase by other institutions, it would appear that an ample variety of prison industries for all the needs of rehabilitative trade

${ }^{61}$ Arizona, 3 Code Ann. (1 939) sec. 47-301, 305.

${ }^{62}$ These statutes will be found in Appendix G, p. I4I.

${ }_{63}$ Indiana Stats. Ann. (1933) sec. 1 3-102.

A list of such statutes will be found in Appendix H, p. 146. 
training is made possible so far as disposition of the products thereof is concerned.

Whether or not the market so provided is sufficient to absorb all the output of a particular type of industry may be questionable. But if one assumes that for rehabilitative training-as distinct from mere occupation of prisoners' time-a considerable variety of industries is desirable, the market provided through purchases by other state institutions ought to be amply sufficient for that particular purpose.

\section{c. Trade Training-Authority to Establish}

If the market for rehabilitative training products is sufficient, the question-ignoring the problem of finances-becomes one of the authority of prison administrators to institute such activities. In this respect there is wide variation in the content of statutes, from that of Illinois with its explicit command that prisoners shall be employed "so far as practicable in occupations in which they will be most likely to obtain employment after their discharge," and that the work "shall be directed with reference to fitting the prisoner to maintain himself by honest industry," ${ }^{64}$ to the simple Arizona provision that "the board shall require of every able-bodied convict as many hours of faithful labor in each day, during his term of imprisonment, as shall be prescribed in the rules of the prison." 65

\section{d. General Education}

The wisdom of general education as a measure of rehabilitation and possible prevention of repeated crime is recognized

${ }^{64}$ Illinois Rev. Stats. (1935) ch. 108, secs. 85, 79 (Jones Ann. Stats. 99.066, 99.057).

${ }_{65}$ Arizona Code Ann. (1939) sec. 47-108. These statutes will be found in Appendix I, p. I 5 I. 
in the legislation of a number of states. Perhaps the broadest statute is that of Indiana which provides that the administrators of each penal institution "shall make the necessary provision for . . . such training in character building and moral rehabilitation of the inmates as may be deemed necessary to reclaim the persons who are incarcerated in such institutions, so that at the expiration of their terms . . . they may be returned to society better fortified to resist the temptations which led to their imprisonment and as useful and self-respecting citizens of the community." ${ }^{66}$ The Idaho statute is rather more specific, though no broader in its scope, and requires that when a prisoner is received into the penitentiary he shall be given an examination in fundamental studies as taught in the common schools of the state and, unless he passes it, "he shall be instructed in such studies as may be deemed practicable and advisable; and each and every prisoner shall be given such courses from the university extension department as may be found practicable." Superintendents of Idaho reformatories are required to make "suitable provision" for education. ${ }^{67}$

The legislative provisions in other states vary from these broad declarations down to absence of any specific provision. ${ }^{68}$

\section{e. Medical and Surgical Treatment}

In contrast with the broad powers given by some statutes for rehabilitative education in general and training in trade skills particularly, the idea that crime is often the product of physical or psychical abnormalities which can be corrected by means of medical or surgical treatment seems not clearly to have been appreciated by legislative groups. One need not

${ }^{66}$ Indiana Stats. Ann. (1933) sec. $13-123$.

${ }^{67}$ Idaho Code (1932) sec. I 9-3904.

${ }^{68}$ A list of the statutes will be found in Appendix J, p. 165. 
accept the theories of some criminologists that all crime is reducible to biological causes, nor admit even that much of it could be prevented by physiological alteration in the individual. But it seems to be established beyond peradventure that some criminality does have its inception in correctible physical or mental abnormalities. Whether the trouble be chronic inflammation of the urethral tract, resulting in overstimulated and criminal sex activity, or be a deficient sugar content in the blood stream which forces a child into petty theft whereby to satisfy his overpowering physical urge for sweets, or be an inferiority complex which causes crime as a self-demonstrative defense mechanism, or whether the motivating cause be some other individual peculiarity of personality, the known instances of conduct correction through correction of the physical causes are too numerous and too well authenticated to be ignored. How numerous such correctible causes are may be matter of undeterminable dispute. Quite possibly they are far more numerous than is generally supposed and the number of demonstrated cases is relatively small only because no real effort has ever been made to discover others.

But be that as it may, the fact that repeated crime does sometimes spring from physical or mental causes which can be eliminated by proper treatment, is sufficiently well recognized to warrant search for other such cases and to call for effort by medical or surgical treatment to prevent repetition of crime. One might therefore expect to find considerable legislative provision for such procedures. But nothing of the sort appears in the statute books.

There are, to be sure, many statutes providing for medical or surgical care of the inmates of prisons, but these are all quite obviously directed toward routine preservation of health. The Alabama code, for example, requires specifically only that prisoners be examined for venereal disease and that 
those found so infected, and other persons found to be afflicted with tuberculosis, be confined separately from other prisoners and be given treatment. ${ }^{69}$ The laws of Arkansas require the full time of a physician whose duty is to provide all necessary medical services for prisoners, prescribe diets for the sick, keep health records, and otherwise function as a prison physician. ${ }^{70}$

But while it seems implicit from the content of the various statutes that what might be called "corrective medicine" was not in the mind of the legislatures which enacted them, many of the statutes are nevertheless broad enough in their actual expression to furnish a general authority for prison administrators to put such corrective measures into operation if the desire to do so were present and the financial conditions made it possible. Thus the Kentucky statute makes it a duty of the board of corrections "To study the sources and causes of crime, delinquency, and dependency and as far as possible suggest and put into effect such remedial measures as may be of benefit to the Commonwealth in the prevention and ultimate eradication of anti-social acts and conditions . . . ."71 In Iowa the board of control is directed "to encourage the scientific investigation, on the part of executive heads and medical staff of the various institutions, as to the most successful methods . . . of treating the persons committed thereto. . . ." 72

In regard to many of these statutes ${ }^{73}$ it might be said, as has been said of the situation in England:

"We do not agree with the view that crime is a disease, or that it is generally the result of mental disorder. We believe, however, that a certain amount of persistent crime-as well

${ }^{69}$ Alabama Code (1940) tit. 22, sec. 265 ; tit. 45, sec. I 58.

${ }^{70}$ Arkansas Digest of Stats. (1937) sec. 12704 .

${ }^{71}$ Kentucky Carroll's Stats. (1930) sec. $216 \mathrm{a}-3$.

${ }^{72}$ Iowa Code (1939) sec. 3329 .

${ }^{73} \mathrm{~A}$ list of such statutes will be found in Appendix K, p. I72. 
as first offense with which we are not concerned-is due to abnormal mental factors. . . . We do not consider that any special statutory provisions are necessary or even practicable at the present time to carry out this experiment. But we believe that if advantage is taken by Local Authorities of the powers conferred on them by the Mental Treatment Act, I930 - . (there might be) some reduction in the amount of certain forms of persistent crime." 74

\section{ASSISTANCE AFTER RELEASE FROM CONFINEMENT}

The social importance of guidance and actual assistance in the avoidance of wrongdoing after release and return to society of persons who have been convicted of crime is clearly recognized almost everywhere-except in the statute-books. Privately established and supported agencies do widespread work along those lines, which has been notably effective in preventing the return of individuals to crime.

The Prison Association of New York, for example, expended nearly $\$ 5$, 000 during I 940 solely for the support and relief of persons recently released from prison who might otherwise have been forced into crime. They interviewed I 800 men released from prison, furnished 800 nights' lodging, 3000 meals, gave out $\$ 4200$ in money, and found 300 jobs. In its report, the Association makes the sapient statement that:

"Probably the greatest problem presented is the need of employment for parolees and probationers. The handicap of an institutional record combined with restrictions involving union membership, defense project contracts, loss of citizenship rights, the effect of the Alcoholic Beverage Control Law which prohibits ex-prisoners from working with establish-

${ }^{74}$ Report of the Departmental Committee on Persistent Offenders, presented by the Secretary of State for the Home Department, London (1932, Cmd. 4090) p. 46. 
ments possessing liquor licenses, ${ }^{75}$ and other barriers met by parolees, serve as deterrents to the obtaining of gainful employment. The problem is complicated and can be solved only with the whole-hearted cooperation of the general public." to

The Women's Prison Association of New York City does valuable work in finding jobs for women released from prison, gives them board and lodging until work can be found, affords them some of the training in trade skills necessary to holding even a simple job, and offers a place for such luxuries as laundry facilities and the mending of clothes until the exprisoner has had time to re-establish herself otherwise. The Osborne Association maintains an Employment and Relief Bureau but pertinently comments that:

"Helping men get jobs is not the only service rendered by the Bureau. In many cases it is necessary to finance lodgings, food, laundry and car-fare for the ex-prisoner until he can secure a job, and in other instances it is necessary to help him secure better clothing, provide bus or train fare to a job, help him get tools or personal belongings out of pawn, and so forth."

A considerable number of private institutions are engaged to greater or less extent in thus protecting the public against reversion to crime by released prisoners. ${ }^{77}$

In contrast with this effort of private agencies is the startling dearth of statutory provision for state activity designed for similar protection of society.

Supervision, in the sense of an effort to discover if a prisoner released on parole misbehaves himself, is commonly provided for in words, even if not with sufficient finances. Moreover, so far as concerns persons who have not actually been discharged from prison but are only released into freedom

${ }^{75}$ To which the report might have added the unwillingness of army authorities to accept ex-convicts in the service, or in production of war material.

${ }^{76} \mathrm{New}$ York Legislative Document (194I) No. 6I, Ninety-sixth Amnual Report of the Prison Association of New York, p. 48.

${ }^{77}$ A partial list of such agencies appears in Appendix O, p. 217. 
on parole, there is language in many statutes which would authorize active assistance toward law-abiding behavior if the financial necessities thereof were provided. The Kentucky statute is fairly typical. It provides that parole officers shall keep informed concerning the "conduct and condition" of each person under their supervision and shall report thereon. In addition it is made their duty to "use all practicable and suitable methods, not inconsistent with the conditions imposed by the court or Department of Public Welfare to aid and encourage persons on probation or parole and to bring about improvement in their conduct and condition." 78

The California law is outstanding in originally making an appropriation of $\$ 29,500$ for the purpose of assisting paroled and discharged prisoners to secure employment, furnishing them tools, and giving them other assistance, and, more recently, permitting the local board of paroles to draw for such purposes against a general appropriation.

The Iowa law also is socially more far-sighted than that of other states and provides a fund of \$1250 from which a parolee under certain conditions can borrow not to exceed $\$ 25 .^{79}$ But as a general proposition it may be said that legislation directed toward prevention of repeated crime by means of assistance to persons discharged from prison simply non est. ${ }^{80}$

This lack of legislation even authorizing aid to ex-prisoners is most apparent in respect to those who have been fully released, either by removal of their parole restrictions or by discharge because the term of sentence has been completed. The Indiana provision is illustrative:

"Hereafter, whenever any person shall be discharged from the Indiana Reformatory or the Indiana State Prison, the su-

${ }^{78}$ Kentucky Acts (1936) ch. 30, sec. 7 .

${ }^{79}$ Iowa Code (1 939 ) ch. r88, sec. $3797 \mathrm{ff}$.

${ }^{80}$ Statutes relating to supervision and aid of persons on parole will be found in Appendix L, p. 182 . 
perintendent or warden thereof shall procure for him and deliver to the proper railroad conductor, a railroad ticket to any point to which such person may desire to go, not farther from said prison than the point from which he was sentenced, give him \$ro in money, a durable suit of clothes, and, from the first day of November to the first day of April, an overcoat. The suit of clothes shall not cost to exceed $\$ 6$ and the cost of the overcoat shall not exceed $\$ 5 . "$ 81

With these clothes and his ten dollars he is turned out into a hostile world, and the state is legally unconcerned with him -until he is again arrested.

For prisoners who are to be released on parole, a job of some sort is usually a prerequisite to release. If the statute itself does not so require, the rules of the parole board usually do. Moreover it appears to be a fairly common practice for the parole officials themselves to assist prospective parolees in finding such work or, perhaps more accurately, for the officials to find a job into which the parolee can be released. But there is no similar requirement that the prisoner have a job, or be provided with one, before absolute release at the end of his sentence. Neither law nor regulation requires a job as prerequisite to such release. Nor does it appear that officials make any great effort toward that end, although a number of the private associations already referred to are active in helping the released prisoner to find honest work.

After a prisoner has found a job, or had one found for him, and has been released on parole, there is in general no pro-

${ }^{81}$ Indiana, 4 Stats. Ann. (1933) sec. $13-257$.

The statutes covering this matter 'will be found in Appendix M, p. 194.

Much the same situation seems to prevail in England. "The arrangements for the re-instatement in industry of persons discharged from detention will obviously be of great importance to the success of the (rehabilitative) scheme. At present the work of assisting prisoners on discharge rests as regards persons discharged from the local prisons on a number of local aid societies which are voluntary bodies receiving a small Government grant, but dependent for most of their funds on charitable subscriptions." Report of the Departmental Committee on Persistent Offenders, presented by the Secretary of State for the Home Department, London (1932, Cmd. 409o) p. $3 x$. 
vision that he must continue in some sort of self-supporting occupation as a condition of his continued freedom. And even more obviously, there is no such provision in respect of persons who have been absolutely released. Anything, therefore, which is done by officials to help either parolees or ex-convicts generally to find new employment is entirely a voluntary assistance not provided for by law. Neither do the laws as now written require anyone to assist such ex-prisoners in finding new jobs when an old one is lost. 


\section{Chapter V}

\section{Actual Utilization of Non-punitive Methods}

$7 \mathrm{HE}$ extent to which rehabilitative procedures and preventive methods other than mere punishment

1. are in fact made use of cannot be made the subject of generalization. In the first place, no general information has been collected concerning the extent of such procedures; and, as was explained at the beginning of this discussion, this study was not directed toward the collection of heretofore unknown data but only toward the assembling and organization of existing but heretofore uncorrelated information. In the second place, the few data which have been gathered indicate so wide a variation in what is actually done under essentially similar legislative enactments as to preclude any generalization of practices. The fact that some particular rehabilitative procedure would be permissible under a fair interpretation of an existing statute does not by any means indicate that such a procedure is actually utilized. On the contrary, though the law may permit, or even explicitly authorize, a desirable activity, the facilities for that activity may be wholly lacking.

\section{THE USE OF REHABILITATIVE TRAINING}

The very great differentiation between what could legitimately be done under existing statutes and what in fact is done may be fairly exemplified by conditions in the West Virginia penitentiary at Moundsville, as shown by a recent report. The West Virginia statute provided broadly that:

"The state board of control . . . may hire any or all convicts confined in the penitentiary at Moundsville to the state road commission, the county court of any county, or to 
contractors engaged in the construction of roads.

"Convicts of both sexes not so employed may be employed by the warden . . . in the manufacture and repair of articles used by the State in conducting the penitentiary, or articles used by any other state institution, or such other articles as the board of control may designate.

"In order to provide employment for convicts not employed as provided in the two preceding sections, the state board of control may let and hire the labor of such convicts, on the piece price system or otherwise, in such branches of business, and for the manufacture of such articles, as in its judgment will best accomplish the ends and subserve the interests of the State. . . ." 82

In a general way this statute might well be considered broad enough to authorize employment of convicts in rehabilitative work. But the actualities are set forth in the Official Report of the Warden for the years I 936-1939, which says:

"Inestimable improvements have been made to the physical properties of this institution, the intrinsic worth of which may well be doubled, since the figures presented represent materials and equipment costs only. Everything possible, commensurate with the money appropriated, has been done for the custody of and care of prisoners. While all these improvements add to safety and security of the prisoners, it is highly significant that not one additional job was created for the vast number of idle population.

"It is a most unhealthy, and hazardous condition, to face an astounding total of I 200 prisoners loafing and lying about in idleness. Whether it be lack of foresight or hope of forestalling the federal Hawes-Cooper Act, it was inevitable that this serious problem sooner or later had to be confronted. Nevertheless, with the enforced withdrawal of contractual prison industries, the penitentiary was found woefully lacking when it came to absorbing or creating work for those thrown out of employment.

"There are but two practical avenues now to which we may direct our re-employment problem. One is for the State Road

${ }^{82}$ West Virginia Code (r93 I) ch. 28, art. 5, secs. 9, I I. 
Commission to engage and keep maintained a force of 800 convicts in public road construction, and the other, is the establishment of industries within the prison for manufacturing of state use goods." ${ }^{83}$

On this last point it may be noted that the pre-existing law specifically authorized the warden to employ convicts in the manufacture and repair of "articles used by the state in conducting the penitentiary, or articles used by any other state institution, or such other articles as the board of control may designate."

The law itself was sufficient, but the facilities were not. Since that report, the legislature has enacted further legislation to the effect that:

"Whereas, the means now provided for the employment of convict labor are inadequate to furnish a sufficient number of convicts with employment, it is hereby declared to be the intent of this act:

"(a) To further provide more adequate, regular and suitable employment . .' . consistent with proper penal purposes;

"(b) To further utilize the labor of convicts for selfmaintenance and for reimbursing this state . . .;

"(c) To effect the requisitioning and disbursement of prison products . . . with no possibility of private profits therefrom."

The board of control is authorized to purchase "equipment, raw materials and supplies and to engage the supervisory personnel necessary" for the production of articles needed in other state institutions. Other institutions are by the same statute required to buy from the penitentiary whatever of their needs it is prepared to supply. ${ }^{84}$

No report has been received since the enactment of that express authority to provide facilities for the employment of the convicts. It is worthy of note, however, that the reasons

${ }^{83}$ West Virginia Penitentiary, Official Report and Statistics, 1936-39, p. 11.

${ }^{84}$ West Virginia Acts (1 939) ch. 104, sec. I ff. 
for the statute as stated in the preamble do not even suggest that the work should be rehabilitative in character, or designed to fit the prisoners for lawful self-support after their release.

\section{THE USE OF EDUCATIONAL REHABILITATION}

The high degree of variance in what is actually done or not done within the permission of essentially similar statutes, and the consequent impossibility of estimating from the existence of any given statute the extent to which non-punitive procedures are in fact utilized, is illustrated by the general educational measures used in the Wisconsin prison as compared with those of North Carolina. The statutes of the two states are not widely different, though the North Carolina legislation is the more broadly directive. The Wisconsin law merely authorizes the chaplain of the prison to hold divine service, to instruct the prisoners in their moral and religious duties, to act as librarian, and "to devote not less than three hours per day, once in each week," to instructing prisoners who need it. He is authorized to employ qualified prisoners to help him. ${ }^{85}$ The North Carolina statute expressly authorizes the organization of classes among the prisoners so that those who desire education in various lines of education may receive it. ${ }^{86}$ Yet the Attorney General's Survey of Release Procedures ${ }^{87}$ notes the North Carolina prison at Raleigh as having "no educational program in $1936-7$," while the educational program at Waupun, Wisconsin, was even then outstanding, with courses in more than 75 subjects, ranging from aeronautics, bee culture, foundry-work, fur farming, through plumbing and poultry raising to upholstering and woodworking.

${ }^{85}$ Wisconsin Stats. (I 94I) sec. 53.06 .

${ }^{86}$ North Carolina Code Ann. (1935) sec. 7732.

${ }^{87}$ United States Department of Justice, The Attorney General's Survey of Release Procedures, Vol. V, Prisons (1939) pp. 232, 247. 
Prevention of further criminality through the use of probation instead of imprisonment has come into widespread utilization. But here again the existence of the power as given by statute is no indication whatever of the extent of its use. The tremendous disparity in sentences given by different judges for essentially similar offenses is well known. ${ }^{88}$ What is perhaps not so generally realized is that: "Equally significant are the variations in the extent to which probation is used in various districts. During the fiscal year ending June 30 , 1939, in one (federal) district 62.4 per cent of all convicted defendants were placed on probation, while in another the percentage was only 4 per cent. The corresponding percentages in the remaining federal judicial districts lay between these two extremes." ${ }^{89}$ Again, one finds Judge $X$ imposing fines on 84 per cent and suspending sentence in 7 per cent of his cases, while his colleague Judge $\mathrm{Y}$ imposes fines on but 34 per cent and suspends in 59 per cent. ${ }^{90}$

So also the extent of release from confinement on parole and the accepted bases for such release are matters of wide variation. In the words of the Attorney General's Survey of Release Procedures:

88 "Several years ago a statistical study was made of the average sentences imposed by every federal district judge in cases involving violation of the liquor laws. - . . The computation made for the fiscal year ending June 30 , I 935 , showed that the average sentence of imprisonment imposed in such cases by one judge was 85 Iays, while the average imposed by another judge in such cases was forty days." McGuire and Holtzoff, "The Problem of Sentence in the Criminal Law," 4 Fed. Probation 20,22 (1940).

"If I oo prisoners are sentenced by Judge $F$, each has thirty-four chances in roo of going to jail, since Judge $F$ gives 34 per cent of all his sentences to penal institutions. If, however, they were to be sentenced by Judge $B$, each would have fifty-seven chances out of roo of going to jail. In other words, it might be figuratively said that of the noo men who were sentenced by Judge $B$, thirty-four would go to jail because of their crimes and twenty-three would go because of the personality of the judge." Frederick J. Gaudet, "Individual Differences in the Sentencing Tendencies of Judges," Archives of Philosophy, No. 230 , p. I9 (1938).

89 "The Problem of Sentence," op. cit. supra note 88, at 22.

${ }^{30}$ George Everson, "The Human Element in Justice," ro J. Crim. L. 9o (1919). 
"The data of the Survey show marked differences in the extent to which parole is used in the various jurisdictions. This is not surprising when notice is taken of the varying factors which influence the use of parole . . . differences in parole organizations, regional differentiations, variances in indeterminate sentence and parole eligibility statutes, wide differences in criminality rates between and within communities, and greatly overcrowded prisons in some sections of the country. . . . Likewise, it is to be noted that within a given State the use of parole varies as between different types of institutions." 91

Its use varies also from year to year. The tables of use, presented by the Survey with the foregoing caveat as to interpretation, show a variation from 94 per cent of prisoners released on parole in Indiana, New Hampshire and Vermont and 93 per cent in New York to 5 per cent in Maryland, I per cent in South Carolina, and no releases in Idaho, Virginia, and Mississippi. ${ }^{92}$

In further illustration of the impossibility of guessing what is actually being done from what the statutes theoretically permit, is the educational program in the Wisconsin penitentiary as set out in the Survey. But here, happily, the illustration is of actualities in excess of what one might expect from the statutes. The legislation itself merely authorizes the chaplain of the prison to hold divine service, to instruct the prisoners in their moral and religious duties, to act as librarian and to "devote not less than three hours per day, once in each week, and oftener, if the board of control shall consider it necessary, to instructing those prisoners who need such instruction in the common branches of English education; and with the consent of the warden call to his assistance in such educational labors such convicts as he may deem qualified." ${ }^{93}$

${ }^{91}$ United States Department of Justice, The Attorney General's Survey of Release Procedures, Vol. IV, Parole (1939) p. I21.

${ }_{92}$ The lack in actual practice of assistance to persons who have been released on parole is indicated by the data in Appendix N, p. 205.

${ }_{93}$ Wisconsin Stats. (I 94I) sec. 53.06. 
This is far less broad and less explicit an authorization than is found in the statutes of several other states. Yet the Attorney General's Survey of Release Procedures says of the Wisconsin state prison:

"By an arrangement with the Wisconsin Free Library Commission, a series of reading courses were arranged on special topics for particular individuals. . . . It is reported in 1934, that 'nearly 500 men are always taking these courses in 75 to 100 different subjects.' . . . The list of reading courses includes the following: (giving 32 topics; from Accountancy and Aeronautics, through Landscape Gardening and Shorthand, to Upholstering and Woodworking). . . In I933, the contract shops were removed from the prison and the space formerly occupied by them given over to a full time educational director and a corps of inmate teachers for a school. With these arrangements, a regular day school in academic subjects and a cell-study program were also inaugurated." ${ }^{94}$

By way of contrast is the North Carolina statute ${ }^{95}$ which specifically authorizes classes among the prisoners so that those who desire may receive instruction in various lines of education. Here the authority is as ample as it is in Wisconsin, but the utilization of that authority is quite different. The only comment of the Attorney General's Survey of Release Procedures is that "fourteen prisons had no education program in 1936-37. These include the following:

North Carolina (Raleigh). . . ."96

${ }^{94}$ United States Department of Justice, The Attorney General's Survey of Release Procedures, Vol. V, Prisons (1939) p. 248.

${ }_{95}$ N. C. Code (1935) sec. 7732.

${ }^{96}$ United States Department of Justice, op. cit. supra note 94 , at 233.

One finds further illustration, if any were needed, of the fact that the actual employment of a desirable practice cannot safely be deduced from the existence of a statute authorizing or directing such a practice, in the Recommendations to the Legislature, New York Legislative Document (1942) No. 52, Ninetyseventh Annual Report of the Prison Association of New York, p. 21. Of Elmira Reformatory it says:- "The intent and expressed purpose of this institution was the housing of the youthful first offender. The intervening time, however, has witnessed a wide and marked departure from the original thought, and re- 


\section{ASSISTANCE AFTER RELEASE}

As was pointed out in the preceding chapter, existing legislation makes practically no provision for assistance after release from prison in the difficult problem of self-support without return to criminality. Neither, it can safely be said, is anything effectively done in actuality by state agencies along these lines. Private agencies are helpful, but limited in their scope and facilities. In most states the parole authorities do find honest employment for the convicts they release on parole, but do not for those who are released because the term of imprisonment has expired. For neither are the state agencies legally obligated to help in finding continued employment, and the replies of parole authorities to interrogation indicate that practically nothing is done in fact by way of assistance after release from prison. ${ }^{97}$

\section{THE GENERAL NEGLECT OF PREVENTIVE PROCEDURES}

From various sources of information one is impressed by the fact that here and there, to some limited extent, a real effort is being made to put into operation as effectively as possible all the crime preventive procedures which the existing law permits.

Nevertheless, one finds to the contrary such assertions as that of Viola Ilma, executive director of the Young Men's Vocational Foundation:

"The majority of youths released from reformatories have no jobs or prospects of jobs, and many of them have no homes. . . . These youthful offenders are especially worth helping in their efforts at self-rehabilitation.

cent studies, made at the institution, indicate that only approximately onefourth of the inmates are first offenders, and over half are of low intelligence. . . The entire plan and program of the institution is retarded by virtue of the character of the prisoners sentenced."

${ }^{97}$ The gist of these replies will be found in Appendix N, p. 205. 
- . True, many correctional institutions have vocational training programs and maintain workshops, however inadequate. But too often the vocational training programs correspond to the work needs of the institutions, and are not realistically adjusted to industrial needs and job trends on the outside." 98

Perhaps the most severe arraignment of existing practices, as distinct from existing possibilities, is the simple, forthright, statistical assertion by the American Bar Association committee on sentencing, probation, prisoners and parole, which reads as follows:

"A statement that I0O,000 penitentiary prisoners out of 162,000 were not being subjected to any conscious, organized rehabilitative efforts of any kind was not challenged by the American Prison Congress before whom it was made.

"Volume V of the Attorney General's Survey of Release Procedures, which deals with penal and correctional institutions, finds that of 136,957 male prisoners in the institutions studied 30,000 were in camps which offered no rehabilitative facilities, 40,000 were housed in quarters so over-crowded as to endanger health and morals, 55,ooo were confined in idleness, and only 35 ,ooo had the benefit of any organized educational activities.

"The reliable and comprehensive reports of the Osborne Association, in its successive Handbooks of American Prisons and Reformatories and its News Bulletin, shows that only here and there throughout the country has modern thought been put to practice." 99

Contrary to what was said at the beginning of this section, perhaps one can safely generalize concerning the actual utilization of methods better designed than punishment for the prevention of repetitious criminality. One may accept the generalization of that same committee: "For the most part our

${ }^{98}$ Report for I 939-40. Present author's italics.

${ }^{99}$ Report presented to the Section of Criminal Law, annual meeting, Sept. I 940, p. 20 . 


\section{UTILIZATION OF NON-PUNITIVE METHODS 83}

prisons and reformatories are operated much as they were before the new concepts and techniques were known." ${ }^{100}$

${ }^{100}$ As an isolated comment, the "Recommendations to the Legislature," New York Legislative Document (194I) No. 6I, Ninety-sixth Annual Report of the Prison Association of New York, p. I5, is illuminating-"IIr. It is recommended that the psychiatric, psychological and allied professional services eliminated in 1939 continue to be restored to the State Department of Correction." Present writer's italics. 


\section{Chapter VI}

\section{Conclusions}

F

ROM all this welter of conflicting philosophies, from the available data of crime and criminals, from judicial opinions and from the content of legislative enactments, certain conclusions are inescapable.

In the first place the conventional, accepted idea of proper treatment of convicted criminals is still the traditional one of punishment. Theories upon which the use of punishment is justified have shifted in popularity. The form of the treatment has altered materially. Life imprisonment has largely been substituted for hanging; mutilation gave place to flogging and flogging in its turn to solitary confinement, or bread and water. The brutalities once part and parcel of punishment have been eradicated or ameliorated. Nevertheless, the essential character of the treatment imposed has not been changed; its form is different, but its nature still is punitive. That idea pervades judicial utterance and legislative enactment. The punitive purpose dominates both the content of the criminal law and its application. It is in fact the essential sum and substance of the law today.

But though punishment is still clearly the purpose of the law, the purpose of the punishment is not so clear. The once academically popular notion that punishment should be imposed only for the purpose of retribution, to the end of exacting an owed expiation, has passed into obsolescence. In the main it has yielded place to concepts of punishment as a preventive of new wrongdoing. But it is by no means obsolete. It still affects both the content of the law and its administration. Today's newer legislation can be accounted for in part only by recognition of the extent to which the motiva- 
tion of revenge for injury accomplished has colored it. The instinctive desire for revenge, for the compelled repayment by an offender of a quid pro quo in suffering, is a social force which has never been wholly argued down, which has definitely influenced the whole process of dealing with convicted criminals and which must necessarily be taken cognizance of in any proposal of legislation to be enacted. It seems safe to say, therefore, that the purpose of treatment of discovered criminals is a composite, in fluctuating proportions, of retrospective, retributive satisfaction and of prospective hope. But no matter how strong the latter element of purpose, regardless of how emphatically the preventive purpose is stressed, the commonly accepted method of treatment, almost wholly relied upon, is still the infliction of unpleasant consequences for the sake of their effect upon the will of the sufferer-it is punishment, in the usual connotation of that term.

A second unavoidable conclusion is the relative ineffectiveness of this punitive process, particularly as a preventive of repeated crime by wrongdoers who have been subjected to it. The light of history precludes an assumption that its failure lies in the mildness of its punishments; the most drastic of penalties have proved equally inefficient. Nor is there substantial evidence that its failures are caused by the infrequencies of its application. On the contrary its most obvious failures and its most notable ones are precisely with the very individuals to whom it has in fact been applied once, twice, or repeatedly. Whether or not a greater assurance of punishment, a greater modicum of inevitability, would more effectively decrease the amount of first criminality one cannot say. Nor need one speculate-the problem of creating that greater assurance has already been struggled with too long to raise a probability of its attainment. The effective possibilities of punishment, as a preventive method must be measured by the actualities of the past and of the present. And by that meas- 
urement the punitive method, particularly in its operation upon those to whom it has in fact been applied, has demonstrated its unsatisfactoriness beyond dispute.

The reasons for this failure constitute a fairly obvious further deduction. In the main the method fails because, though it may return its victims to social freedom with a strengthened desire to refrain from crime, it returns them also without the slightest increase in ability to do so. Too often it returns them to freedom with only a wish to evade renewed punishment, no desire at all to abstain from crime. But whether it succeeds in creating a will to abstain, or merely a will to sin more safely, it operates only upon the will, not upon the capacity to abstain. Only when the treatment applied ceases, in part at least, to be a punitive method can it actively seek to better its subjects' ability in self-support. The present system also fails as a preventive because, being punitive, it must release a subject at the end of his specified penal term, without regard to either his will or his capacity to refrain from further crime. It fails also because as a matter of fact it has been and still is a mass procedure which is not designed to protect its less vicious subjects from the character destructive contagion of other criminal mentalities. To these three basic causes of the failure of punishment to prevent repetition of crime must be added a fourth reason; it leaves its victims, after punishment, to their own resources, without state assistance in the avoidance of further criminality.

Though the process of punishment might conceivably be individualized and the character-destructive effect of mass treatments might thus conceivably be remedied, the other causes of its failure are inherent; they are elements in the very definition of punishment; they cannot, so long as the treatment of convicted criminals remains primarily punitive, be corrected. The failure of punishment cannot be prevented while the process of punishment is retained as the primary method 
of treatment. Yet that the faults, and therefore the method, must be eliminated if society is to be successfully protected against repeated crime is an inescapable conclusion. Some fundamentally different method of treatment must be substituted. The only question is as to the essentials of that substitution.

Presumably the substitute could not wisely, even were attainment practicable, depart entirely from the notion of unpleasant consequences as a result of conviction of wrongdoing. Prevention of repeated crime is but one objective, though the main one, of criminal law enforcement. The prevention of first crime cannot be ignored. Nor might it be altogether safe to disregard that vigorous insistence of the man on the street that wrongdoers be punished because they deserve to be punished. It may well be doubted that disorder would increase and private persons might take into their own hands the exaction of retribution if instincts of revenge were left unsatisfied by official action. More likely, a public which believes that its freedom from crime is being adequately protected will acquiesce peaceably in whatever reasonable means are adopted for that end. Still, satisfaction of that undeniably prevalent wish for retributory suffering as a consequence of injury done must be given some heed in consideration of any substitute for the common, punitive method of dealing with convicted criminals.

In so far as the prevention of crime by others than the person dealt with is concerned, psychologists agree and history demonstrates that neither fear of monetary amercement nor the physical distress of imprisonment are of material effect. What deterrence there may be springs from more subtle influences; from the fear of public condemnation demonstrated through punishment, from the conduct habits and inhibitions created by open and notorious application in specific cases of what might otherwise be mere abstract formulations of 
right and wrong, from the instinct of individuals to conform with the expressed beliefs and demanded conduct of the herd. If this be so, punishment, in the sense of treatment administered for the primary purpose of causing suffering, is not necessary to attainment of the end sought. All the deterrent effect, the explicit expression of group reprobation, the demonstration of its standards of right and wrong, its insistence upon conformity with its group ideas, can be expressed by conviction and individualized corrective treatment as effectively as by conviction and stereotyped punishment. Whether the revenge instincts would be as well satisfied by the former as by the latter may be questioned. But what dissatisfaction might result, it seems safe to say, would operate only as an obstacle to adoption of the substitute treatment, not as a source of evil resulting from its adoption.

Let us say, then, that the treatment of convicted criminals need not be punitive, even for the accomplishment of those ends of the criminal law which are collateral to the effect of the treatment upon the individual himself. So long as the process of treatment emphatically demonstrates a reprobation of specific conduct and a condemnation of persons guilty of such conduct, it need not be designed primarily to cause pain or suffering. With that premise accepted, it is possible to postulate affirmatively what the essence of the treatment should be. The extent to which desirable changes in the method of treatment could possibly be instituted under existing legislation has already been considered. The forced conclusion is that change which is real and fundamental enough to accomplish the purpose can be brought about only through new legislation. Many of the necessary rehabilitative procedures, it is true, are in a sense authorized by existing statutes; others could be established without actual conflict with existing law. But some of the necessary preventives of repetition are not now permissible even by implication. Moreover, the whole 
statutory structure is built upon the notion of "deterrence" through "punishment." The ideas of "rehabilitation" and of active assistance in abstention from crime are not explicit enough to give character to administrative action. New laws are needed as a clear expression that newer procedures are desired.

The new legislation must be such as to eliminate the faults which cause the failure of the punitive system. Hence:

It must limit the possibility of character degradation.

It must keep dangerous persons under supervision, or even in segregation from society, for so long as their freedom is manifestly a danger.

Above all it must set up every reasonable facility and procedure for correcting the conditions which make an individual prone to crime and for increasing his capacity as well as his will to abstain therefrom.

And when it has done all that, and returns him to social freedom, it must continue its protection and must actively. assist him in law-abiding conduct.

The details of operation of these four procedures may vary widely; the essential matter is that they, regardless of their details, rather than mere punishment, shall characterize the treatment of convicted criminals. When that is brought to pass, the present intolerable burden of crime and punishment and unceasingly repeated crime despite the punishment cannot but be materially decreased. 


\section{PART II}

STATUTES AND RELATED

MATERIALS 


\section{PART II}

\section{Statutes and Related Materials}

T $\mathrm{N}$ the various compilations of this Appendix, the names of some states are absent from the list. This does not 1 necessarily mean that there is no legislation whatever in those states relating to the particular subject matter, but rather that if there is any it does not appear to the compiler to be sufficiently pertinent or illuminating to warrant inclusion. In Arkansas and Florida, for example, there are statutory requirements that white and negro prisoners shall be kept separate. In the list of statutes relating to "Separation of Types of Prisoners" (Appendix C), it would not be accurate to list these states as having "no provision" concerning classification. Yet the provision itself has no real relation to the matter under discussion. So also in some of the states there are provisions concerning various matters which if quoted apart from their context would be misleading unless accompanied by commentary. Thus, as the purpose of these statutory references and excerpts is not the furnishing of an encyclopedic statement of the law of each state, but is rather to exemplify the manner and extent to which certain philosophies of treatment have been expressed in legislation, the policy was followed of simply omitting from each list those states in which nothing sufficiently illuminating was found.

In listing the statutes which follow, no attempt has been made to determine their constitutional validity. For example, an early Alabama statute on suspension of sentence by the court ${ }^{101}$ was held to be an unconstitutional attempt to transfer to courts the pardoning power granted by the constitution to

${ }^{101}$ Acts Extra Session (x 932) p. 54. 


\section{THE PREVENTION OF REPEATED CRIME}

the governor. ${ }^{102}$ The courts in a few other states have shown similar reactions. It has seemed unnecessary, however, for the purpose of this compilation, to search out the judicial decisions concerning the legislation.

Statutes pertaining specifically to the treatment of juvenile, or minor, or youthful prisoners are not generally included in this compilation, because such special provisions, by the very fact that they are special, indicate nothing, except possibly by uncertain indirection, of the state's policies concerning convicts in general.

${ }^{102}$ Montgomery v. State, 231 Ala. I, I63 So. 365 (1935). 


\section{Appendix A}

\section{Release Before Commitment}

$\mathrm{I}^{\prime}$

$\mathrm{N}$ the absence of statute, the prevailing rule is that while courts may delay the imposition of sentence for various they cannot suspend, except temporarily, the operation of a sentence already imposed. "It is a fundamental doctrine that no court has an inherent right to suspend the operation of a sentence theretofore pronounced by it. . . . Stating it conversely, the power of the court to suspend sentence must come from statutory provisions, and not otherwise; and while some of our sister states hold differently, we are committed to this doctrine." 103 "Even if the courts at common law had the power to suspend sentences it would be doubtful if we could reconcile that practice with our system of government. A suspension is nothing more than a reprieve, and an indefinite suspension is equivalent to a pardon or at least putting it in the power of the court to judge whether or not a duly convicted criminal should be punished. It would nullify the punishment for crime which is fixed by the legislature and which it is the duty of the judiciary to impose." 104

A few courts do adhere to the contrary opinion. "Courts have immemorially exercised the power of either suspending sentence or deferring sentence to a particular day. . . . This power could not be taken away from them except by express and unequivocal statutory enactment." 105 "Although in many jurisdictions the power of the court to suspend execution of sentence has been denied as an infringement on the pardoning

${ }_{103}$ Pagano v. Bechly, 21 I Iowa 1294, 1296, 232 N. W. 799 (I931).

${ }_{104}$ Ex Parte Fisher, 95 W. Va. 397, 400, 121 S. E. 288 (1924).

${ }_{105}$ Com. ex rel. McGinnis v. Ashe, 330 Pa. 289, 29 1, 199 Atl. 186 (1938). 
power of the executive, that doctrine has never prevailed in this state." 106

Statutes, however, have quite generally established a wide judicial discretion to refrain from imposition of punishment.

Alabama. Code (1940) tit. 42, sec. 19 ff. Courts from which appeal lies directly to court of appeals or to supreme court may suspend execution of sentence and place on probation, and may impose conditions upon the probationer, except when the sentence is to death, or to imprisonment for more than ten years, or when the defendant has previously been sentenced in any jurisdiction for a crime involving moral turpitude.

Arizona. 3 Code Ann. (1939) sec. 44-2229. "Where discretion is conferred upon the court as to extent of the punishment" and "it shall appear that there are circumstances in mitigation of the punishment, or that the ends of justice will be subserved thereby" the court may suspend sentence and place on probation.

Arkansas. Digest of Stats. (I937) sec. 4053. "Whenever, in criminal trials in a circuit court, a plea of guilty shall have been accepted or a verdict of guilty shall have been rendered, the judge trying the case shall have authority, if he shall deem it best for the defendant and not harmful to society, to postpone the pronouncement of final sentence and judgment upon such conditions as he shall deem proper and reasonable as to probation of the person convicted. . . ."

California. Penal Code (194I) sec. I203. If the court "shall determine that there are circumstances in mitigation of punishment prescribed by law, or that the ends of justice would be subserved by granting probation to the defendant, the court shall have power in its discretion" to do so, unless the defendant has been convicted of any one of sixteen specified crimes and at the time of the crime or of his arrest was unlawfully armed with a deadly weapon, or unless he has previously been anywhere convicted of a felony.

Colorado. 4 Stats. Ann. (1935) ch. 140, sec. I. The court, if satisfied that the best interests of the public and of the defendant will so be served, may, with the approval of the district attorney, suspend

${ }^{106}$ Couture v. Brown, 82 N. H. 459, 460, r 35 Atl. 530 (x 926 ). 
imposition or execution of sentence for any crime except murder in the first or second degree.

Connecticut. Gen. Stats. (I930) sec. 6487, (1939 supp.) sec. 1463e. Except "after commitment to the State Prison" court may suspend sentence "when the mitigating circumstances clearly justify such action" and may, but need not, commit to a probation officer.

Florida. Stats. (194I) sec. 948.o I. If it appears that the defendant is not likely again to commit crime and that the ends of justice do not require that he suffer a penalty the court may suspend the imposition of sentence and place him on probation.

Georgia. Code Ann. (1933) sec. 27-2501. Judge may of his own motion or a recommendation of jury reduce all felonies, except certain specified crimes such as murder, rape, mayhem, arson, etc., to misdemeanors and punish as such.

Sec. $27-2702$. "Where it appears to the satisfaction of the court that the circumstances of the case and the public good does not demand or require the defendant's incarceration" the court may allow a person convicted of misdemeanor or of felony reduced to misdemeanor to serve time under supervision outside of chain gang, jail, or other prison.

(An act of the extra-session of 1937-8 appears to have broadened the foregoing somewhat, but was itself repealed and the earlier law reinstated by sec. $27-2525$, Acts of 1939.)

Idaho. I Ann. Code (1932) sec. 19-250I. The judge may "commute the sentence and confine the defendant in the county jail, or, if the defendant is of proper age, in the state industrial school, suspend the execution of judgment or withhold judgment on such terms and for such time as it may prescribe, and, in either event, may put the defendant on probation . . . "unless he is convicted of treason or murder or has been previously convicted of felony.

Illinois. Rev. Stats. (1935) ch. 38, sec. 785 ff. (Jones Ann. Stats. $37.772 \mathrm{ff}$.) Court may, after entry of judgment when nothing remains to be done by the court except to pronounce sentence, admit a defendant to probation if it appears that the defendant "may be reformed and that the interest of society will be subserved" unless he is convicted of one of twelve specified offenses, or has previously been 
convicted of crime greater than a misdemeanor (with some exceptions).

Indiana. 4 Stats. Ann. (1933) sec. 9-2209. Court may suspend sentence for any crime except murder, arson, burglary, rape, treason, kidnapping, or a second conviction of robbery, whenever it finds that the offense was committed under such circumstances that the convicted person "should not suffer the penalty imposed by law for such offense if he or she shall thereafter behave well, or whenever such court shall find and determine that by reason of the character of such person or the facts and circumstances of such case, the interest of society does not demand or require that such person shall suffer the penalty. . . ." The court may impose conditions such as restitution, reparation, or the support of dependents.

Iowa. Code ( I 939) sec. 3800 . The court before which a person has been convicted of any crime except treason, murder, rape, robbery, arson, or certain liquor-law violations, may suspend sentence and put him on probation if he has not previously been convicted of felony, is free from venereal disease, and is assured of suitable employment.

Kansas. Gen. Stats. Ann. (1935) sec. 62-2203. Court may, before or after sentence has been pronounced, parole a person for the first time convicted, except for murder, forcible rape, arson, robbery, burglary, or larceny of automobile or livestock, if satisfied that "if permitted to go at large he will not again violate the law."

Kentucky. Acts (1936) ch. 30, p. 74. Court may suspend sentencing any person convicted of crime except one whose punishment is fixed by the jury at life imprisonment or death. Conditions such as reparation, restitution, or support may be imposed.

Louisiana. Code of Crim. Proc. ( I932) art. 530 ff. "When there is a conviction of any felony in the District Court of this state, except murder, rape, perjury, burglary of a dwelling, robbery, arson, incest, bigamy, abortion and assault with intent to rape, the court may suspend the sentence when the jury shall find in their verdict that the defendant has never before been convicted of a felony in this state or any other state and shall recommend that the sentence be suspended." The defendant may demand testimony as to his general reputation as an aid to the jury in deciding whether or not so to recommend. 
Maine. Rev. Stats. (1930) ch. 146, sec. 26. "Sentence shall be imposed upon conviction . . . provided that the court . . . may in its discretion continue the matter for sentence, suspend sentence or stay the execution of sentence. . . ."

Maryland. Ann. Code (1939) art. 27, sec. 680. "The courts may suspend sentence generally or for a definite time, and may make such orders and impose such terms . . . as may be deemed proper. . . "

Massachusetts. 9 Ann. Laws (1933) ch. 279 sec. I ff. Court may suspend execution of sentence and place on probation, except where penalty is punishment by death or imprisonment for life, or for a crime an element of which is being armed with a dangerous weapon, or in cases of second conviction on felony charge or certain other exceptions.

Michigan. 3 Comp. Laws ( I929) sec. I7371. (Mich. Stats. Ann. $\$ 28.1131$.) Court may place a first offender on probation after conviction of any crime except murder, treason, robbery armed, breaking and entering an occupied dwelling in the night time, "where it appears to the satisfaction of the court that the defendant is not likely again to engage in an offensive or criminal course of conduct and that the public good does not require that the defendant shall suffer the penalty imposed by law."

Minnesota. 3 Mason's Stats. (I927) sec. 9936. Courts of record may place on probation "any person who has been convicted of the violation of a municipal ordinance or by-law, or of any crime for which the maximum penalty provided by law does not exceed imprisonment in the state prison for ten years," and may stay the execution of such sentence whenever it is of the opinion that the welfare of society does not require that he shall suffer the penalty imposed by law. The court may also suspend the sentence of one who has been sent to the county jail, even after it has been partially served.

Mississippi. Code Ann. (1930) ch. 21, sec. 1298. Circuit courts in misdemeanor cases are authorized to suspend the sentence and to suspend execution of a sentence or any part thereof.

Missouri. I Rev. Stats. (I939) sec. 4201. Courts may "parole first offenders sentenced to the penitentiary for any crime but murder, 
rape, arson, or robbery," if satisfied that they will not again violate the law. They cannot so parole after delivery of the offender to the warden of the penitentiary.

Montana. 5 Rev. Codes (1935) sec. 12078. The court "may suspend the execution of sentence and place the defendant on probation" if he has never before been imprisoned for crime and appears not likely to again engage "in an offensive course of conduct." This provision does not apply to persons convicted of murder, arson, burglary of an inhabited dwelling house, incest, sodomy, rape without consent, assault with intent to rape, or administering a poison.

Nebraska. Comp. Stats. (1929) sec. 29-22 I4. The court may "enter an order, without pronouncing sentence, suspending further proceedings, and placing the accused on probation," if he believes that the accused will refrain from further criminal acts. This seems not to be applicable to second offenses of murder, treason, rape, arson, burglary, robbery, or larceny.

New Jersey. I Rev. Stats. (1937) sec. 2:199-1. The court may suspend the imposition or execution of sentence for any crime or offense "when it shall appear that the best interests of the public as well as of the defendant will be subserved thereby."

New Mexico. Stats. Ann. ( I94 I) sec. 38-1204. The justice of the peace may suspend sentence where defendant is a minor or is husband or wife of the prosecuting witness.

Sec. 42-170r. A court may "suspend any sentence imposed upon such terms and conditions as it shall deem proper, and such sentence shall go into effect upon order of the court upon breach of any such terms or conditions by the person convicted."

New York. 39 McKinney's Consol. Laws Ann. (1938) sec. 2188 . The court may suspend sentence or impose sentence and suspend execution, except in cases where the penalty is death or life imprisonment or an armed felony or a fourth felony offense.

North Carolina. Code Ann. (1935) sec. 4665 (I). Courts of record may suspend imposition or execution of sentence and place the defendant on probation, or impose a fine and also place the defendant 
STATUTES: RELEASE BEFORE COMMITMENT IOI

on probation; except for crimes punishable by death or life imprisonment.

North Dakota. Comp. Laws (1913) sec. ro950. The court may suspend the execution of sentence and place on probation, except in case of certain crimes listed, defendants never before imprisoned.

Ohio. Throckmorton's Code Ann. (r 940) sec. 1345 1-8b. "Any court sentencing a person for misdemeanor forbidden by statute or ordinance, may at the time of sentence remit the same or suspend such sentence in whole or in part."

Sec. 13452-1. The court may suspend imposition of sentence and place the defendant on probation, if it appears that his character and circumstances are "such that he is not likely again to engage in an offensive course of conduct, and the public good does not demand or require that he be immediately sentenced;" except where the conviction has been for murder, arson, burglary, incest, sodomy, rape, assault with intent to rape, and poison.

Oklahoma. Stats. (I94I) tit. 22, sec. 991. "Whenever any person shall be convicted in any court of record for any crime other than murder, manslaughter or arson, the Judge trying said cause may, after sentence, suspend said judgment and sentence, and allow said person so convicted to be released on his own recognizance. . . ."

Oregon. 3 Comp. Laws Ann. (1940) sec. 26-1224. "The courts having jurisdiction of criminal or quasicriminal actions . . . when it shall appear that the best interests of the public as well as of the defendant will be subserved thereby, shall have power to suspend the imposition or execution of sentence for any crime or offense, and also shall have power to place the defendant on probation for definite or indefinite period, not to exceed five years."

Sec. 26-1230. All courts and judges have the power to parole persons, "as hereinafter provided."

Sec. 26-1231. First offenders whose sentence does not exceed ten years, may be considered by the court-and at its discretion it may "parole such person and permit him or her to go and remain at large under the supervision of the court, or under the supervision of any 
prisoners' aid society. . . . "The court has no power to parole after the prisoner has been delivered to the penitentiary.

Pennsylvania. Purdon's Stats. Ann. (1930) tit. I9, sec. 1051. The court shall have the power to suspend sentence, and place the defendant on probation for a definite period, if the crime convicted for is not murder, poisoning, kidnapping, incest, sodomy, buggery, rape, arson, robbery, or burglary, and if "it does not appear to the said court that the defendant has ever before been imprisoned for crime, either in this State or elsewhere."

Rhode Island. Gen. Laws (1938) ch. 496, sec. I8. "Whenever any prisoner shall be arraigned before the superior court, and shall plead guilty . . . he may be at any time sentenced by the court; provided, that if at any time the court formally defers sentencing the defendant, and thereupon a written agreement concerning said deferring of sentence is entered into between the attorney-general and the prisoner, and filed with the clerk of said court, thereafter the court may only impose sentence within five years from and after the date of such written agreement. . . ."

South Carolina. I Code of Laws (1942) sec. 1039. "The circuit judges of this State shall have the power and authority, in their discretion, to suspend sentences imposed by them, upon such terms and upon such conditions as in their judgment may be fit and proper: Provided, Said power and authority shall not extend to cases of felony."

Acts and Joint Resolutions (1942) Act No. 562, sec. I. ". . . That after conviction or plea for any offense, except a crime punishable by death or life imprisonment, the judge of any Court of record with criminal jurisdiction at the time of sentence may suspend the imposition or the execution of a sentence and place the defendant on probation.

South Dakota. Code (1939) sec. I3.520r. "The judge of any court having jurisdiction to try an offense where the sentence does not exceed one year shall have power to parole the defendant . . . ," provided it is the defendant's first conviction.

Tennessee. Michie's Code Ann. (I938) sec. I I822. Judge may suspend sentence till next term of court "if it shall appear . . . that the prisoner is only technically guilty, or that there are circum- 
stances or conditions . . . tending to mitigate his offense, or if it is the prisoner's first offense, and it is not likely that he will again engage in an offensive and criminal course of conduct if released, and in the opinion of the presiding judge the public good does not require that the defendant shall suffer the disgrace of imprisonment. . . ." In the meantime the defendant may apply to the governor for a pardon.

Texas. 3 Vernon's Code of Crim. Proc. (1925) art. 776. "When there is a conviction of any felony in any district or criminal district of this State, except murder, perjury, burglary of a private residence at night, robbery, arson, incest, bigamy, seduction, and abortion, and the punishment assessed by the jury shall not exceed five years, the court shall suspend sentence upon written, sworn application made therefor by the defendant, filed before the trial begins." This applies to first offenders only.

Art. 776a. "When a defendant has entered a plea of guilty and has waived his right of trial by Jury, and has consented to be tried by the Court and there is a conviction of any felony, except murder, perjury, burglary of a private residence at night, robbery, arson, incest, bigamy, seduction and abortion, and the punishment . . . shall not exceed five years, the Court shall have the right and power to suspend the sentence of the defendant during his good behavior." This also applies only to first offenders.

(Art. 776a was added by Acts (1931) ch. 43, sec. 4.)

Utah. 6 Code Ann. (1943) sec. 105-36-17. Court can suspend imposition or execution of sentence and place on probation with conditions, as requiring payment of fine, or restitution, etc.

Vermont. Pub. Laws (1933) sec. 8872 . State probation officer may be directed by the court to investigate a certain case, and he may recommend that in such a case the "person, if convicted, be placed on probation. Such court shall pass sentence on the accused, if he is convicted, and may then suspend all or part of such sentence and place the person . . . in the care and custody of the state probation officer.

Virginia. Code (1942) sec. 1922b. "After a plea, a verdict or a judgment of guilty in any court having jurisdiction to hear and determine the offense, with which the prisoner at the bar is charged, 


\section{I04 THE PREVENTION OF REPEATED CRIME}

if there be circumstances in mitigation of the offense, or if it appear compatible with the public interest, and in any case after a child has been declared delinquent or dependent, the court may suspend the imposition or the execution of sentence, or commitment and may also place the defendant on probation under the supervision of a probation officer, during good behavior, for such time and under such conditions of probation as the court shall determine. . . ." Such suspension is forbidden in cases of second conviction for driving while drunk.

Washington. 4 Remington's Rev. Stats. Ann. (1932) sec. 2280. "Whenever any person never before convicted of a felony or gross misdemeanor shall be convicted of any crime except . . . , the court may in its discretion, at the time of imposing sentence upon such person, direct that such sentence be stayed and suspended until otherwise ordered by such court, and that the sentenced person be placed under the charge of a parole or peace officer during the term of such suspension, upon such terms as the court may determine. In no case shall a sentence be suspended under the provisions of this section unless the prisoner if sentenced to confinement in a penal institution be placed under the charge of a parole officer, who is a duly appointed and acting officer of the institution to which the person is sentenced."

10 id., sec. 10249-5a. After conviction by plea or verdict of guilty of a felony offense, the court, upon application or its own motion, may summarily grant or deny probation, or may hear and determine later the matter of probation, and the conditions, if granted. Provided probation shall not be granted to any person not eligible to receive a suspended sentence.

West Virginia. Code Ann. (1937) sec. 6291 (8) ff. Courts of record may suspend imposition or execution of sentence of persons convicted for the first time of a felony for which the maximum penalty is less than life imprisonment, and of misdemeanants regardless of previous conviction.

Wisconsin. Stats. (I94I) sec. 57.01. Court may suspend sentence, except sentence for murder, causing death by injury to railroad, armed assault and theft, kidnapping, breaking and entering armed, 
bank robbery, burglary with explosives, pandering, and deserting wife and child; if it appears that the "character of the defendant and the circumstances of the case indicate that he is not likely again to commit crime." Upon such suspension, the prisoner is placed on probation.

Wyoming. Rev. Stats. (1931) sec. 33-1501, First offenders found guilty of any felony except murder, rape or arson may be paroled by the court at its discretion.

District of Columbia. Code (1940) tit. 24, sec. I02. The district court has power, except in cases of treason, homicide, rape, arson, kidnapping, or a second conviction of felony, to place the defendant on probation "when the best interests of the public as well as of the defendant" will be promoted thereby.

Federal. 18 U.S.C.A. sec. 724. Courts have power, "when it shall appear to the satisfaction of the court that the ends of justice and the best interests of the public, as well as the defendant, will be subserved thereby," to "suspend the imposition or execution of sentence and to place the defendant upon probation," for not over five years, except after conviction of a crime punishable by death or life imprisonment.

The court has no power to release on probation after sentence is begun. United States v. Murray, 275 U. S. 347 (1928). 


\section{Release After Commitment}

NCE imprisonment has begun, the possibility of character deterioration as a consequence thereof has also begun. In every state the deterioration can be stopped because the imprisonment can be terminated before expiration of the period specified in the sentence by the governor or by a specially created board. The variant extent to which such boards are given power to act is shown in the following statutes. In some states, as in Alabama, Iowa and Minnesota, immediate release is permitted if the parole board thinks wise. In others, such as Connecticut, Georgia, or New York, immediate release appears possible, though the statute is not precise. In Delaware it is permitted under certain limited conditions. In others, such as Indiana and Wyoming, prisoners in certain institutions, but not those in others, can be immediately released. In the great majority of jurisdictions, however, boards are not authorized to release until a specified period of imprisonment has elapsed. In none of the statutes is the authority to release expressly predicated upon the danger of character degradation.

Alabama. Code (1940) tit. 42, sec. I ff. The board of pardons and paroles is "charged with the duty of determining what prisoners serving sentences in the jails and prisons of this state may be released on parole and when and under what conditions." There appears to be no limitation upon the promptness with which the board may act.

Arizona. Code Ann. (1939) sec. 47-Iro ff. The board of paroles may release any prisoner confined upon an indeterminate sentence whose minimum term of imprisonment has expired.

Arkansas. Digest of Stats. (1937) sec. 12734. The board may release on parole after service of the minimum sentence, or one-third 
of a definite sentence. Persons confined in the boys' industrial school may be paroled at any time.

California. Penal Code (I94. I) sec. 3049. In general, board of prison terms and paroles may release from confinement after at least half the minimum term of sentence has expired, but numerous collateral provisions require longer terms of imprisonment in specified types of case.

Statutes and Amendments (1941) ch. 937, sec. 1766. Convicts committed to the Youth Correction Authority may be released at any time.

Colorado. I Stats. Ann. (1935) ch. 48, secs. 547, 558. Persons committed under indeterminate sentence may be released after expiration of the minimum term.

Connecticut. Gen. Stats. (I930) sec. 6509, (I939 supp.) sec. 1470-e. "Any person sentenced to the State Prison, after having been in confinement under such sentence for not less than the minimum term" may be released on parole.

But, Gen. Stats. (I930) sec. I998, (I935 supp.) sec. $787 \mathrm{c}$ provides that "Jurisdiction over the granting of, and authority to grant . . releases, conditioned or absolute, in the case of any person confined in the State Prison . . . shall be vested in the board of pardons. Said board shall have authority to grant pardons, conditioned or absolute . . . at any time."

Gen. Stats. (1930) sec. I830 ff. Males between sixteen and twenty-five if sentenced for less than life may be committed to state reformatory. Board of directors of reformatory may release on parole, apparently at any time.

Delaware. Rev. Code (I935) sec. 4I50. Prisoners sentenced for a year or more may be, with some specified exceptions, paroled after one-half of the term has been served. In case of peculiar mental or physical conditions requiring special treatment, parole for that purpose may be granted at any time.

Florida. Stats. (I94 I) sec. 947.16. Persons sentenced to more than one year of imprisonment are eligible for parole after six months.

Georgia. Code Ann. (1933) sec. 77-504. The statute, unlike its predecessor statute, makes no requirement of a minimum term 
before parole. It gives the prison and parole commission power to parole "upon the prison record of said prisoner and his history before his conviction." This may, by implication, require at least some time in prison.

Idaho. I Code Ann. (1932) sec. 19-3908. Prisoners may be paroled after service of the minimum of a sentence.

Illinois. Rev. Stats. (1935) ch. 38, sec. 807. (Jones Ann. Stats. 37.765.) "No prisoner . . . shall be eligible to parole . . until he or she shall have served the minimum limit or duration of imprisonment recommended in the advisory recommendation of the court in which sentence was imposed" or in the case of sentence for a specific time, one-third of that time.

Indiana. 4 Stats. Ann. (1933) secs. I3-246, I3-410, I3-620, 13-712, 13-921. Prisoners in the state prison and in the prison for women can be paroled after service of a minimum sentence. Those in the state reformatory and schools for boys and girls may be paroled at any time.

Iowa. Code (1939) secs. 3786, 3787, 3788. The board of parole has power to parole persons committed to the penitentiary, or reformatories, and make its own rules and conditions of parole. Apparently it could, so far as the law is concerned, release without any minimum term.

Kansas. Gen. Stats. Ann. (1935) sec. 62-1525. The prison board is given power to parole but only after the minimum term has been served.

Kentucky. Carroll's Stats. (1930) sec. 3828-2. Prisoners must serve at least half of a sentence of imprisonment for less than ten years, and at least six years of a longer sentence.

Sec. $2095 \mathrm{c}-3$. Youthful offenders confined in the state reformatories may apparently be released at any time.

Louisiana. Code of Crim. Proc. (1932) art. 725. Only persons serving indeterminate sentences may be paroled and then only after service of the minimum term.

Maine. Rev. Stats. (1930) ch. 147, sec. 28, as amended Laws (1933) ch. 153, sec. I. Parole is permitted only after service of the minimum term of sentence with the deduction provided by law. 
Maryland. Ann. Code (1939) art. 4I, sec. 74 ff. Apparently the only parole power is vested in the governor, but he may release at any time.

Massachusetts. 4 Ann. Laws (1933) ch. I27, sec. 128 ff. Prisoners in state institutions must serve at least two-thirds of a minimum sentence before parole. It is possible to read the statute as permitting parole from jails and workhouses at any time.

Michigan. 3 Comp. Laws (1929) sec. 17543-43. (Mich. Stats. Ann. \$28.2103.) Parole may be granted only after service of a minimum sentence, unless at request of the parole board the trial judge or his successor recommends earlier release.

Minnesota. 3 Mason's Stats. (1927) sec. 10765 ff. Except to persons serving a life sentence, parole may be granted at any time, with no requirement of minimum period of imprisonment. But sec. I 0824 requires service of a minimum sentence by persons committed to the state reformatory.

Mississippi. Appears to have no parole provisions, though governor may grant a conditional pardon at any time.

Missouri. 2 Rev. Stats. (1939) sec. 9163. Apparently the paroling process is a phase of the pardoning power, administered by an advisory board. Releases could probably be made at any time if the board should choose to so advise. But sec. 9120 requires that persons committed to the reformatory must serve seven-twelfths of the time for which sentenced.

Montana. 5 Rev. Codes (1935) sec. 12264 ff. Prisoners must serve one-half the term, or a minimum term, for which sentenced.

Nebraska. Comp. Stats. (1929) sec. 29-2623. Parole cannot be granted until the minimum term of sentence has expired.

Sec. 83-1501. Certain feeble-minded prisoners must submit to sterilization before parole.

Sec. 83-1403. Females committed to the women's reformatory may be paroled at any time.

Nevada. Comp. Laws (1929) sec. I1 569 ff. The board may release on parole after one year of imprisonment, less time off for good conduct. 
New Hampshire. Rev. Laws (1942) ch. 429, sec. 22. Release on parole may be granted after the expiration of the minimum term of sentence.

New Jersey. I Rev. Stats. ( I 937) secs. 2:198-I, 30:4-145 ff, 30:4-106. The board of pardons may grant parole at any time. The board of managers of state institutions may parole only at expiration of the minimum term, but apparently an inmate of the reformatory could be released at any time.

New Mexico. Stats. Ann. (194I) sec. 42-1 7or ff. Prisoners are not eligible for parole until the minimum sentence has been served.

New York. IoB McKinney's Consol. Laws Ann. (1938) sec. 212. As to persons confined under indeterminate sentence, "The time of his release shall be discretionary with the board of parole, but no such person shall be released until he has served such minimum sentence nor until he has served one year."

Under sec. $28 \mathrm{I}$ it is possible that persons confined in the reformatory could be released at any time. "The board of parole of a reformatory, in accordance with rules adopted by such board . . . may conditionally release a prisoner." No minimum time of confinement is mentioned.

Secs. $200 \mathrm{ff}$. seem to give local boards certain powers to parole at any time.

North Carolina. Code Ann. (1935) sec. 7757 (9). Parole by the governor under the statute, as distinct from his constitutional power, is permissible, when the prisoner has served one-fourth of his minimum sentence, or one-fourth of a definite one.

North Dakota. Comp. Laws (19I3) sec. Iro97 ff., amended, Laws (1939) ch. 130, p. 195. The board of pardons apparently can release at any time, but the statute requires application for release to be filed at least thirty days before a meeting of the board, which can consider such applications only twice a year.

Ohio. Throckmorton's Code Ann. (1940) sec. 22 Io. "At the expiration of the minimum sentence diminished as herein provided, each prisoner shall be eligible for parole as provided by law."

Oklahoma. Stats. (I94 I) tit. 57, sec. 345. Any convicted person is eligible for parole immediately. 
Oregon. Comp. Laws Ann. (1940) sec. 26-2305. The board of parole may establish rules and regulations for the parole of any prisoner except fourth offenders and those sentenced to death, but persons over 20 years of age and sentenced to more than 5 years imprisonment for certain crimes must have served at least one-third of the sentence.

Pennsylvania. Purdon's Stats. Ann. (1930) tit. 6I, secs. 292, 308,570 . Prisoners in the state penitentiaries must serve the minimum term of sentence, but those in the state industrial schools can be paroled at any time, subject, however, to a wait from the meeting of the board at which application is made until the next meeting.

Rhode Island. Gen. Laws (1938) ch. 617, sec. 3 ff. Prisoners in the state prison or county jails must serve at least half the period for which sentenced.

South Carolina. 2 Code of Laws (1932) sec. 3099. Parole appears to be under the governor's constitutional power and may take place at any time.

South Dakota. Code (1939) sec. 13.5301. The governor may parole a convict serving an indeterminate sentence after he has served the minimum less good time allowance, or a convict under a determinate sentence after he has served a stated proportion, depending on his age, of the sentence.

Tennessee. Michie's Code Ann. (1938) sec. II797 (14). Prisoners must serve minimum sentence or at least one year before being paroled.

Texas. 3 Vernon's Code of Crim. Proc. (1925) art. 959. "Meritorious prisoners . . . may be allowed to go upon parole . . . subject to the provisions of this title, (apparently no time restrictions) and to such regulations and conditions as may be made by the Board of Prison Commissioners, with the approval of the Governor."

Utah. 4 Code Ann. ( I 943) sec. 67-0-7. Release on parole may be granted any time after conviction except when sentence is for first degree murder. There is no statutory requirement of delay resulting from formal necessities of application or consideration. 
Vermont. Pub. Laws (1933) secs. 8885, 8888. The governor may grant a conditional pardon on application of any person sentenced for the term of a year or more.

Virginia. Code ( 1 942) sec. 1922b. In cases of conviction for misdemeanor the court may suspend any unserved portion of the sentence.

Washington. Io Remington's Rev. Stats. Ann. (1932) sec. 10249-2 ff. At least six months must elapse before the period of imprisonment is fixed by the board; parole may be granted at any time thereafter.

West Virginia. Code Ann. (1937) sec. 6291 (23). Prisoners not under life sentence who have not previously been twice convicted of felony are "eligible for parole at any time."

Wisconsin. Stats (194I) sec. 57.06. Prisoners must serve at least the minimum or one-half the maximum sentence, whichever is less, before being paroled.

Wyoming. Rev. Stats. (I931) secs. 33-I303, 80-30r. Convicts generally are eligible for parole only after service of the minimum sentence. Prisoners in the industrial institute can be released on parole at any time.

District of Columbia. Code (1940) tit. 24, sec. 204. "Whenever - . it shall appear to the Board of Indeterminate Sentence and Parole . . that any prisoner serving an indeterminate sentence is fitted by his training for release, that there is a reasonable probability that such a prisoner will live and remain at liberty without violating the law, and in the opinion of the board such release is not incompatible with the welfare of society, said Board of Indeterminate Sentence and Parole may, in its discretion, authorize the release of such prisoner on parole. . . ." Apparently no minimum service of sentence is required.

Federal. $\quad$ I 8 U.S.C.A. sec. 7 14. Every prisoner confined for a definite term of over one year, or for life, may be released on parole if he has served one-third of the time for which sentenced, or fifteen years if sentenced for life.

Sec. 723. Nothing in section 714 shall be deemed to impair the power of the President to grant a pardon or commutation. 


\section{Appendix C}

\section{Separation of 'Types of Prisoners}

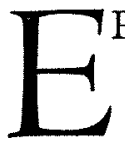

FFECTIVE classification and separation of prisoners for the purpose of preventing character destructive contacts appears scarcely to have been thought of by legislatures, except in terms of age, or, occasionally, in respect to the difference between first offenders and recidivists. Illinois gives perhaps the broadest powers of classification, authorizing such "divisions" as seem expedient in the light of considerations relating to age and character, separation of first offenders from recidivists, psychiatric conditions, and "such other criteria of classification as may be dictated by penological science." Louisiana also authorizes classification "according to the most modern and enlightened system of reformation." Michigan requires examination of each individual in order that he may be confined "in the institution suited to the type of rehabilitation required in his case." These, however, are the exceptional statutes. And even in these states the effective operation of the classification system must depend upon the extent to which actual facilities for it have been provided.

In the great majority of states two or more types of institution have been set up; one for adults, another for younger offenders, and perhaps others, such as "prison camps," for convicts requiring less rigorous discipline, or less absolute confinement than others. The permissible "classification" is then extended to placement in one or another of these institutions. Within the range of the various institutions existing in the state, the problem of separation and limitation of harmful contacts is well enough solved. But as a rule the range of institutions and consequent opportunity for classification is narrow. 


\section{4 THE PREVENTION OF REPEATED CRIME}

Statutes applicable to jails only are not included herein.

Alabama. Code (1940) tit. 45, sec. 38. "All state convicts under eighteen years of age shall, at the discretion of the director, be separated and worked apart, as far as practicable from all other convicts, at a place to be designated as a reformatory, . . . keeping in view their moral and intellectual improvement," and the director may remove from the reformatory any convict if it appears that "by his conduct he is not benefited" by confinement therein.

The Code Ann. (1928) included the following provision:

Sec. 3585 . "The board may order transfer of a convict from one prison to another as it thinks expedient."

California. Statutes and Amendments (194I) ch. 937, sec. 1766. Youthful convicts committed to the Youth Correction Authority may be confined under such conditions as the Authority from time to time considers wise.

Connecticut. Gen. Stats. (1930) sec. 1982. Any prisoner under thirty years of age having less than ten years of minimum sentence to serve and who "in the opinion of the board of directors of the prison, would be benefited by the training provided at the Connecticut Reformatory, may be transferred" thereto. If he proves not amenable to reformatory methods he may be returned to the prison.

Sec. 1837 . Prisoners may be transferred from the reformatory to the Junior Republic, if the latter is willing to receive them.

Delaware. Rev. Code (1935) secs. 4134, 4I48. Prisoners of tender years and those young in crime must be separated from the older and more hardened criminals.

Georgia. Code Ann. (1933) sec. 77-519. The prison commission is authorized to transfer prisoners from one penal institution to any other penal institution in the state and may require that youthful or first offenders be segregated from other prisoners.

Sec. 77-346. The prison commission is authorized to segregate convicts between the ages of $\mathrm{I} 6$ and $2 \mathrm{I}$ from contact with confirmed criminals and to transfer any prisoner under 18 to the Georgia State Training School. 
Sec. 77-347. "The Prison Commission is authorized to provide separate camps or quarters and to segregate prisoners and convicts according to their individual characteristics or tendencies."

Illinois. Rev. Stats. (1935) ch. 108, sec. 106. (Jones Ann. Stats. 99.089.) The department of public safety may determine divisions of the penitentiary system, to include a psychiatric division and such others "as it may deem expedient in light of considerations relating to the age and character of the inmates, the necessity of preserving first offenders from contact with recidivists, and such other criteria of classification as may be dictated by penological science. . . ."

Ch. I08, sec. I ro. (Jones Ann. Stats. 99.093.) The department of public safety has "full power to transfer prisoners from one division to another as often as the nature of the individual case or the exigencies of administration may require."

lowa. Code (1939) secs. 3732, 375 I ff. The board of control may transfer prisoners from penitentiary to reformatory or from reformatory to penitentiary, but prisoners over thirty years of age must be placed in the penitentiary.

Louisiana. Code of Crim. Proc. (1932) art. 1432. The board of control may make rules "for the grading and classifying of the convicts according to the most modern and enlightened system of reformation. . . ."

Maryland. Ann. Code (1939) art. 27, sec. 788. Board of correction may transfer prisoners back and forth between the house of correction and the penitentiary whenever it deems that "prison discipline" will be furthered thereby.

Massachusetts. 4 Ann. Laws (1933) ch. 127, sec. 97 ff. Prisoners in the state prison may be removed to the reformatory and returned again to prison, or may be moved from reformatory to state farm or jail.

Michigan. 3 Comp. Laws (1929) sec. 17543-65. (Mich. Stats. Ann. $\S 28.2125$.) Under the rules promulgated by the director with the approval of the commission, the assistant director in charge of the bureau of prisons may cause the transfer or re-transfer of any pris- 


\section{II6 THE PREVENTION OF REPEATED CRIME}

oner from any penal institution to which he was committed to any other penal institution, or temporarily to any state institution for medical or surgical treatment.

Sec. I7543-67. Promptly after confinement prisoners are to be given physical examination and classified. The classification committee shall "make and complete a comprehensive study of such prisoner, including physical and psychiatric examinations to the end that he may be confined in the institution suited to the type of rehabilitation required in his case."

Minnesota. 2 Mason's Stats. (1927) sec. 10825. "The board of control may transfer from the reformatory to the state prison and from the state prison to the reformatory, whenever, in its judgment, such transfer will be advantageous to the person transferred, or to the institution from which such transfer is made."

Mississippi. 2 Code Ann. (1930) sec. 5777. Youthful convicts shall be kept away from hardened criminals as far as practicable.

Missouri. 2 Rev. Stats. (1939) sec. 9118. The department of penal institutions may transfer from the reformatory to the penitentiary prisoners who are more than twenty-five years of age, second offenders, and incorrigible prisoners whose presence in the reformatory appears to be detrimental to the well-being of the other inmates. Such persons may be re-transferred to the reformatory at the request of the superintendent with approval of the board of commissioners.

Nebraska. Comp. Stats. (1929) sec. 83-1008. The board of control may transfer incorrigible prisoners from the reformatory to the penitentiary.

Nevada. 5 Comp. Laws (1929) sec. 11472." . . . it shall be the duty of the warden of the state prison to classify and separate the prisoners into three grades as follows: . . . those appearing to be corrigible or less vicious . . . those appearing to be incorrigible or more vicious, but . . . competent to work and . . . reasonably obedient . . those incorrigible or so insubordinate as to seriously interfere with the discipline of the prison. . . ."

New Jersey. I Rev. Stats. (1937) sec. 2:192-10. Upon application of the board of freeholders of a county, prisoners in county institutions may be transferred from one institution to another. 
Sec. 30:4-83. An inmate of any correctional institution may be transferred to any charitable hospital, relief, or training institution.

New York. IoB McKinney's Consol. Laws Ann. (1938) sec. 135. Commissioner may transfer prisoners from one prison to another with reference to the respective capacities of the several state prisons, or with reference to the health or reformation of the prisoners.

Ohio. Throckmorton's Code Ann. (1940) sec. 2139 . Inmates of the Boys' Industrial School whose presence in the school appears to be detrimental to the welfare of the institution may be transferred to the reformatory.

Sec. 2140. Incorrigible prisoners in the reformatory whose presence appears to be detrimental may be transferred to the penitentiary.

Oklahoma. Stats. (1941) tit. 57, sec. 132. “. . . Said State Board of Public Affairs may, in its discretion, transfer prisoners from the State penitentiary at McAlester to the reformatory at Granite, and may likewise transfer prisoners from the reformatory at Granite to the penitentiary at McAlester, when in its judgment it is necessary so to do; to separate the confirmed and incorrigible criminals from those who do not require the restrictions placed around them that the confirmed criminal requires; provided, that the authority to transfer prisoners herein given shall never be used to impair the efficiency of, or to destroy, either of said penal institutions."

Oregon. 8 Comp. Laws Ann. (1940) sec. 127-6ro. All persons in the penitentiary between the ages of eighteen and twenty-one may be transferred to the state training school by the governor, "provided, that in the event that any minor transferred from the penitentiary to the state training school should prove incorrigible, then the governor . . . shall be authorized to transfer such minor from the state training school to the penitentiary."

Pennsylvania. Purdon's Stats. Ann. (1930) tit. 61, sec. 491. Whenever there is a vacancy in the reformatory there may be selected from among "the youthful, well-behaved, and most promising convicts in the state prisons," certain prisoners to be transferred to the reformatory "for education and treatment . . . thereof."

Sec. 495. Any prisoner at the reformatory may be "temporarily" transferred to the state prison if it shall be shown that, at the time of 


\section{8 THE PREVENTION OF REPEATED CRIME}

his conviction he was more than twenty-five years old, or had been previously convicted of a crime. The board of trustees may also transfer to the state prison any "apparently incorrigible prisoner."

Rhode Island. Gen. Laws (1938) ch. 63, sec. 19. The chief of division of jails and reformatories "may in his discretion transfer any inmate" of school for boys, county jail, or penitentiary to reformatory for men "when he believes that such transfer will best serve the purpose of reforming such inmate. . . . " He also may transfer any reformatory inmates to the penitentiary, jail, etc.

South Carolina. I Code of Laws (1932) sec. 2034. Board of welfare of the industrial school has power to transfer to the state penitentiary "any white female . . . who is more than eighteen years of age, and whose presence in said industrial home for girls appears to be seriously detrimental to the welfare of the institution."

Tennessee. Michie's Code Ann. (1938) sec. 12117 . "Convicts shall be graded and classified in such a manner as shall be most conducive to prison discipline and the moral status of the inmates." Minors and those who "appear corrigible or less vicious than others, and susceptible to control and observance of prison laws, and disposed to maintain themselves by honest industry after their discharge," shall be kept separate from the other prison inmates. "Only one convict shall be kept in each cell unless absolutely necessary to confine more than one."

Texas. 17 Vernon's Rev. Civil Stats. (1925) art. 6r66j. “. . The manager . . . shall have power . . . to make provision for the separation and classification of prisoners according to sex, color, age, health, corrigibility, and character of offense upon which the conviction of the prisoner was secured."

Utah. 5 Code Ann. ( I 943) sec. 85-9-25. Prisoners shall be classified and separated into three types: "those appearing to be corrigible or less vicious than the others and likely to obey the laws . . .; those appearing to be incorrigible or more vicious, but . . . competent to work . . ., those who are incorrigible, or so insubordinate or so incompetent . . . as to seriously interfere with the discipline or productiveness of the labor of the prison. . . ."

Vermont. Pub. Laws (1933) sec. 8819. Prisoners may be transferred from the penitentiary to the house of correction and vice versa, 
on the written order of the governor, but "a prisoner shall not be so transferred without his consent."

"A minor confined in the state prison or the house of correction in execution of a sentence may be transferred to the industrial school to serve the remainder of his sentence, upon the written order of the governor."

Washington. 1o Remington's Rev. Stat. Ann. (1932) sec. 10249-5. Whenever in its judgment, the welfare of any prisoner or prisoners confined in any penal institution requires that he be removed from one institution to another, the board having control of such institution has authority to order such removal.

West Virginia. Code Ann. (1937) sec. 2703. Boy in industrial school who could have been committed to penitentiary, may be returned to court and there resentenced to penitentiary, if industrial school is "unable to benefit him," and he is a detriment there.

Governor may remit sentence of offender under eighteen to penitentiary, to industrial school, if warden of penitentiary and superintendent of industrial school agree such is advisable.

Wisconsin. Stats. ( I94I) sec. 54.07. "With the approval of the governor" the state board of control may transfer any prisoner "whose continued presence there is considered detrimental to the other inmates," from reformatory to the state prison.

In like manner prisoners may be transferred from the prison to the reformatory.

Wyoming. Rev. Stats. (I93I) sec. 80-306. The governor may transfer prisoners under the age of twenty-five from the state prison to the industrial institute if "public interest and the reform of such convict would be subserved thereby."

Federal. $\quad$ I 8 U.S.C.A. sec. 745. Prisons shall have "such arrangement of cells and yard space as that prisoners under twenty years of age shall not be in any way associated with prisoners above that age, and the management of the class under twenty years of age shall be as far as possible reformatory."

Sec. $753 \mathrm{ff}$. "The Attorney General is also authorized to order the transfer of any person . . . from one institution to another if in his judgment it shall be for the well-being of the prisoner or relieve 


\section{THE PREVENTION OF REPEATED CRIME}

over-crowded or unhealthful conditions in the institution where the prisoner is confined or for other reasons."

Secs. 901 ff., providing for additional "institutions for confinement of male persons" give the Attorney General broad powers of control and management, especially (sec. 907) "to facilitate the development of an integrated Federal penal and correctional system which will assure the proper classification and segregation of Federal prisoners according to their character, the nature of the crime they have committed, their mental condition, and such other factors as should be taken into consideration in providing an individualized system of discipline, care, and treatment of persons committed to such institutions." 


\section{Appendix D}

\section{Segregation During Dangerousness}

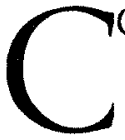

ONFINEMENT and segregation from society of persons who are "insanely" dangerous has long been a commonplace procedure. Similar segregation of persons who, though they do not fall within the conventional significance of insanity are nevertheless "criminally" dangerous to society, is anything but commonplace. An individual who has offended for twenty, thirty, fifty, or even one hundred times despite as many repeated punishments may perhaps not be insane, in any accepted legal connotation of that term, but he seems manifestly as dangerous to the peace, if not to the actual safety, of society as though he were fit material for an "asylum," or "hospital." Yet no legislation now on the statute books makes such segregation possible.

The few provisions looking in that direction require that in addition to demonstrating a tendency toward repeated criminality he must also be in some way mentally deficient. They do not, however, set up a specific distinction between the "mental deficiency" so required and the "insanity" or "idiocy" or other mental abnormalities which would normally, of itself, justify segregation in an institution for the insane or feeble-minded. The Illinois statute, for example, provides for segregation of "sexual psychopathic persons" until cured. It defines a psychopathic person as one who "is suffering from a mental disorder, and not insane or feeble-minded." But wherein the distinction lies, and whether the effect of the statute is in reality broader than the possibility of segregation under the state laws concerning insanity has not been decided. It is a fair guess that the medical profession would suffer considerable perturbation about differentiating a person so "in- 
sane" as to be sexually dangerous, hence confinable under the insanity laws; one so "mentally defective" as to be sexually dangerous but confinable only under this statute; and one in fact sexually dangerous, as indicated by repeated offenses, but yet not so mentally defective as to be confinable under either this statute or the insanity laws, hence confinable only under the criminal law and only for a relatively short period. The Minnesota statute, however, might possibly be satisfied by a simple showing of persistence in repetition of sexual offenses.

Though most of these few statutes limit their application to mental defectives who have a tendency to sexual crimes, the Massachusetts and New York statutes cover the field of criminality in general. But the New York statute raises even more doubt than the others as to whether it does in fact cover any persons who could not be confined under the general mental abnormality laws, since it defines a mental defective, somewhat inconsistently, as one "who for his own welfare or the welfare of others or of the community requires supervision, control or care and who is not insane or of unsound mind to such an extent as to require commitment to an institution for the insane."

An earlier Michigan statute to the same effect as the present one was held unconstitutional. ${ }^{107}$ The opinion leaves one uncertain whether the majority of the court thought there was something inherently unconstitutional in confining a person merely because his freedom would be dangerous to the public, without additional proof of insanity, or condemned the statute only because of certain formal defects. The Minnesota court's decision in respect of that state's statute ${ }^{108}$ indicates clearly its belief that segregation as a necessary method of social protection need not depend for its constitutionality upon a finding of what is commonly called insanity.

${ }^{107}$ People v. Frontczak, 286 Mich. 51, 28 I N. W. 534 (1938).

${ }^{108}$ State ex rel. Pearson v. Probate Court, 205 Minn. 545, 287 N. W. 297 (1939), affirmed 309 U. S. 270 (1939). 
California. Codes, Gen. Laws and Const. (I939 supp.) Welfare and Institutions Code, sec. $5500 \mathrm{ff}$. When it is properly alleged to the court that a person charged with crime is a "sexual psychopath" the court must postpone trial or sentence and investigate the truth of the allegation. A sexual psychopath is defined as "any person who is affected, in a form predisposing to the commission of sexual offenses against children, and in a degree constituting him a menace to the health or safety of others, with any of the following conditions: (a) Mental disease or disorder. (b) Psychopathic personality. (c) Marked departures from normal mentality." If the court finds him to be such a person, it may adjourn the criminal proceeding, or suspend the sentence, and commit him to a state hospital for the insane, where he must remain until "he has improved to such an extent that he will not be benefited by further treatment and is no longer a menace to the health or safety of others."

Sec. $7050 \mathrm{ff}$. A "defective or psychopathic delinquent" is defined as a minor who is mentally defective or psychopathic and who is habitually delinquent, or tends to become so, to the extent that he is a menace to the health, person, or property of himself or others. If such a person is not properly subject for commitment to the state correctional school, or home for feeble-minded, or hospital for the insane, he is to be committed to "a state institution for defective or psychopathic delinquents" "for an indeterminate period" and his attainment of the age of twenty-one years does not terminate his confinement. He must remain in custody until he ceases to be a defective or psychopathic personality.

After his discharge, the court may "proceed with the trial, or impose sentence, as the case may be."

Illinois. Rev. Stats. (1935) ch. $3^{8}$, sec. 820 ff. (Jones Ann. Stats. 37.665 ( I) ff.) "All persons suffering from a mental disorder, and not insane or feeble-minded, which mental disorder has existed for a period of not less than one year, immediately prior to the filing of the petition hereinafter provided for, coupled with criminal propensities to the commission of sex offenses, are hereby declared to be criminal sexual psychopathic persons."

When a person charged with a criminal offense appears to be such a sexual psychopath, he is to be examined in accord with certain 


\section{THE PREVENTION OF REPEATED CRIME}

stipulated procedure. If found to be such a criminal psychopathic person, he must be committed to the control of the state department of public safety to be kept safely by it "until such person shall have fully and permanently recovered from such psychopathy."

Massachusetts. 4 Ann. Laws (1933) ch. I23, sec. 113 ff. At any time prior to final disposition of a criminal case in which the defendant if convicted could be punished otherwise than by life imprisonment or death, certain officials may petition that he be committed as a mentally defective delinquent. If he is determined to be so mentally defective, or habitually delinquent, or likely to become so habitually delinquent that he "may become a menace to the public," but is also found not to be so far mentally defective as properly to be committed to an institution for the insane or school for the feeble-minded, he may be committed to a reformatory, or other state institution there to remain until he becomes "mentally and physically capable of taking his place in the community."

Michigan. 2 Comp. Laws ( 1929) sec. 699I-1 ff. (Mich. Stats. Ann. $\$ 28.967$ ( 1 ) ff.) "Any person who is suffering from a mental disorder and is not insane or feeble-minded, which mental disorder has existed for a period of not less than one year and is coupled with criminal propensities to the commission of sex offenses is hereby declared to be a criminal sexual psychopathic person."

"When any person is charged with a criminal offense and it shall appear that such person is a criminal sexual psychopathic person" the prosecuting attorney may institute proceedings to have him so declared. If he is declared so to be, "then the court shall commit such person to the state hospital commission to be confined in an appropriate state institution under the jurisdiction of either the state hospital commission or the department of corrections until such person shall have fully and permanently recovered from such psychopathy."

No person who has been so dealt with may thereafter be tried upon the original criminal charge.

Minnesota. 3 Mason's Stats. (1927) sec. 8992-184a ff. Psychopathic personality "means the existence in any person of such conditions of emotional instability, or impulsiveness of behavior, or lack of 
customary standards of good judgment, or failure to appreciate the consequences of his act, or a combination of any such conditions, as to render such person irresponsible for his conduct with respect to sex matters and thereby dangerous to other persons."

If a person is found to be such a sexual psychopath he is subject to the laws concerning insane persons. A distinction between such a state of mind and insanity in its usual connotation is indicated by another section of the statute:

Sec. 8992-1 84c. The fact that one is a psychopathic personality is not a defense to any criminal charge "unless such person is in a condition of insanity, idiocy, inbecility, or lunacy within the meaning of the laws relating to crimes and criminal procedure." 109

New York. IoB McKinney's Consol. Laws Ann. (1938) sec. $438 \mathrm{ff}$. "Male mental defectives over sixteen years of age charged with, arraigned for or convicted of a criminal offense may be committed to the state institution for defective delinquents at Napanoch," after certain examination and certification. If such persons have been committed to a penal institution, they may be transferred from there to the Napanoch institution. They may be kept at Napanoch until the terms of the penal sentence have expired. They may then be kept in continued confinement there upon examination and certification that they are still "mentally defective" to such extent that they are not "reasonably safe to be at large."

Inasmuch as the statute does not define "mental defective" in such a way as to include persons who could not be confined in nonpenal institutions regardless of their criminality, it seems to be of a different type from those of Illinois and Michigan. In other words, it does not even purport to segregate convicted criminals beyond the term of deserved punishment because they are dangerous, but only

${ }^{109}$ Of this statute the Minnesota supreme court (State ex rel. Pearson v. Probate Court, 205 Minn. 545, 287 N. W. 297 (1939), affirmed 309 U. S. 270 (1939)) said, "While the abnormalities of the group placed under the jurisdiction of the probate court by this act differ in form from those which characterize inebriates, idiots, and insane persons, the need for observation and supervision is the same. . . In the interest of humanity and for the protection of the public, persons so afflicted should be given treatment and confined for that purpose rather than for the purpose of punishment. This we believe to be true even though their mental deficiencies might not be such as to require absolving them from the effects of the criminal statutes." 
to regulate the procedures in applying to a particular group the rule (38A Consol. Laws Ann. sec. 123; roB ibid. sec. 383 ) that all mentally defective persons, whether criminal or not, may be segregated.

Ohio. Throckmorton's Code Ann. (1940) sec. I345I-I9. The phrase "mentally defective" is defined to mean one afflicted with a mental disease or disorder, or in a psychiatric condition which renders him likely to be an habitual criminal, and therefore renders a penal sentence for a particular crime an inadequate protection to the community against possible further criminal conduct of such prisoner.

Sec. I $345 \mathrm{I}-20$. When it appears to the court that a prisoner either before or during trial or awaiting sentence is "mentally defective," the court may "enter an order of indefinite commitment" in such available institution as the court considers most suitable, where the prisoner is to remain until the court is satisfied that he is no longer mentally defective.

Oregon. 8 Comp. Laws Ann. (1940) sec. 127-305. If any person convicted of a delinquency or crime should be judged feebleminded by an examining board, he shall be committed to an institution for feeble-minded for an "indeterminate period," and he shall not at any time be "detained in any place provided for the detention" of criminals.

Pennsylvania. Purdon's Stats. Ann. (1930) tit. 6r, sec. 541-3. "When any person over the age of fifteen years is convicted of crime before any court, or is held as a juvenile delinquent by any juvenile court, or is detained in any prison, industrial school, workhouse, house of correction, penitentiary, or any other penal or correctional institutions under sentence, and such person is, in the opinion of the court or the superintendent, jail physician, or warden of the institution where maintained, so mentally defective that he should be cared for and maintained in the Pennsylvania Institution for Defective Delinquents, such superintendent, physician or warden shall make application. ." He shall be examined by two qualified physicians or a psychiatrist and if found to be "mentally defective and has criminal tendencies" the court shall transfer such person to the above institution. 
Sec. 541-6. If the person's sentence shall expire before his recovery, "he shall be detained in the said institution until his mental condition has so improved as to warrant his discharge."

Federal. 18 U.S.C.A. sec. 87 I ff. These sections authorize the establishment of an institution for convicts who are found to be "insane, afflicted with an incurable or chronic degenerative disease, or so defective mentally or physically (as) to require special medical care and treatment." When the term for which any such person was sentenced has expired, it is the duty of the superintendent of such hospital (sec. 878) to notify "the proper authorities of the State, District or Territory" in which such person resided or from which he was committed that such person is about to be released and that he is "still insane or a menace to the public." What the authorities so notified are to do about it, the statute does not provide.

21 U.S.C.A. sec. 227. The Attorney General may order narcotic addicts transferred to certain institutions for treatment. If any such addict is found to be not cured of his addiction, he is privileged to apply for further treatment. The statute gives no authority for the confinement of an uncured addict beyond the term of his original sentence, except at his own request.

The Swiss Federal Criminal Code of 1937 carries a clear expression of segregation for the purpose of protection against socially harmful persons, in contradistinction to imprisonment for the purpose of punishment. Article 63 provides that as a general rule "the court shall mete out penalties in accordance with the guilt of the offender, considering the motives, previous conduct and the personal situation of the convicted person." But article 42 makes an exception, or an addition, that "Whoever has already served many sentences for felonies or misdemeanors and is inclined to felonies, misdemeanors, disorderly conduct or idleness, and again commits a felony or misdemeanor punishable by confinement, may be placed under detention by the court for an unlimited period. In this instance the detention shall take the place of the sentence imposed." 110

The Spanish law of 1933, Boletín Legislativo, vol. 239, p. 385 , 110 "The Swiss Federal Criminal Code" translated by Walter Friedlander and W. Abraham Goldberg, 30 J. Crim. L. I ff. (x939). 
provides that persons guilty of certain activities may be declared (Art. $9 \mathrm{ff}$.) in a special finding by the courts to be dangerous and subject to measures of social security, and that (Art. 7) after they have served the punitive sentence for the offense committed they may be subject to further preventive detention. Most of the activities enumerated in the law upon which the court's finding of dangerousness may be predicated are not serious crimes, and, in and of themselves, would not subject the offender to more than a short period of punitive imprisonment. They are, e. g., vagrancy, pandering, receiving stolen goods, begging, gambling, habitual public drunkenness, concealment of identity, frequenting criminal resorts.

The Cuban Criminal Code in Book I, title IV, provides traditional punishments for offenses, and in addition, Book IV, sets up "measures of security" by which persons, Art. 48, showing certain predispositions toward crime and, Art. 580, adjudged dangerous by the court may be, Art. $585 \mathrm{ff}$., ordered to be under supervision or in confinement for a period of from one year to a lifetime, unless the order is subsequently revoked and a finding that the necessity for custody no longer continues.

Again, as in the Spanish law, the court's finding of social dangerousness may be predicated upon activities which would not be severely punishable merely as crimes. 


\section{Appendix E}

\section{Commitment of Persons Addicted to the Use of Intoxicants}

TEG

ISLATION providing for segregation because of habitual intoxication or use of drugs occupies a position intermediate of that concerning treatment for crime and that of treatment because of mental abnormality. It makes habitual intoxication a form of repetitious criminal conductif it can properly be called such-which in and of itself calls for segregation longer than mere punishment would justify. On the other hand, many of the statutes, e. g., California, Michigan, New York, permit such segregation, not "until cured" as in other states, but for a specified period only.

Alabama. Code (1940) tit. 22, sec. 249 ff. Persons who habitually use narcotic drugs "so as to endanger the public morals, health, safety, or welfare" or who are "so far addicted to the use of such drugs as to have lost the power of self-control with reference to his or her addiction" may be committed to a private institution if able to pay for cure there, otherwise to some hospital or institution owned by the United States. "The care and treatment of persons committed under this section shall be designed to rehabilitate them and restore them to mental and physical health."

California. Codes, Gen. Laws and Const. (1939 supp.) Welfare and Institutions Code, sec. $7100 \mathrm{ff}$. "Chronic inebriates," who are defined as persons "so far addicted to the use of alcoholic beverages as to be unable or unwilling to continuously abstain from their use . . . and who . . . endangers himself or the person or property of others . . ." may be committed to a "state inebriate colony" for a period of not more than two years.

Colorado. 3 Stats. Ann. (1935) ch. 58, sec. 27. Any person addicted to the use of drugs "in a manner contrary to the public wel- 
fare" may be committed to a state, county, or city hospital or institution or to the common jail of the city or county. The person may be discharged whenever it appears to any magistrate that such person is no longer addicted to the use of drugs or in the discretion of the magistrate.

Connecticut. Gen. Stats. (1930) sec. I791. "Habitual drunkards - . so addicted to the intemperate use of narcotics or stimulants as to have lost the power of self-control" may be committed "to some inebriate asylum in this state" for indefinite treatment.

Delaware. Rev. Code (1935) 4100, sec. 205. Persons addicted to the use of drugs in a manner contrary to the public welfare, the use of which is not prescribed by a physician, may be committed to a State, County, or City hospital or institution. "Whenever it shall appear to any Justice of the Peace that such person is no longer addicted to the use of the aforesaid drugs in a manner contrary to the public welfare, or in his discretion, he may order a discharge from such commitment. . . "

Florida. Stats. (1941) sec. 398.18. Persons who habitually use narcotic drugs so as to endanger the public morals, health, safety, or welfare may be committed to an institution for treatment. "The care and treatment of persons committed . . . shall be designed to rehabilitate them and restore them to mental and physical health." The physician or superintendent in charge of the institution may parole persons committed, but they shall be discharged only by the committing magistrate or his successor on the recommendation of the superintendent or physician in charge.

Georgia. Code Ann. (1933) sec. 42-818. Persons who use narcotic drugs "so as to endanger the public morals, health, safety, or welfare" or who are "so far addicted to the use of such drugs as to have lost the power of self control" with reference to their addiction may be committed to an institution for treatment. "The care and treatment of persons committed under this section shall be designed to rehabilitate them and restore them to mental and physical health."

Idaho. 3 Code Ann. (1932) sec. 64-216. ". . . any person so far addicted to the intemperate use of narcotics or stimu- 
lants as to have lost the power of self-control, or is subject to dipsomania or inebriety" shall be committed "for a definite period, not to exceed two years" and "confined in one of the state insane asylums."

Iowa. Code (I 939) sec. $3478 \mathrm{ff}$. "Persons addicted to the exces" sive use of intoxicating liquors" may be committed to an institution designated by the board of control, there to be "retained in custody until cured."

Louisiana. 2 Gen. Stats. (1939) sec. 3308. "The habitual use of cocaine, opium or its derivatives, except as administered, prescribed or dispensed by a physician, is hereby declared to be dangerous to the public health and safety." A person addicted to their use may be committed to an institution and may be discharged whenever the chief medical officer of the institution certifies that he has been sufficiently treated.

Maine. Rev. Stats. (1930) ch. 22, sec. 131. "A person, alleged to be suffering from the effects of the use of an opiate, cocaine, chloral hydrate, or other narcotic may be committed to the care of any general hospital receiving aid from the state. . . ."The person may be restrained no longer than 90 days.

Maryland. Ann. Code (1939) art. 16, sec. 56. Habitual drunkards, that is, persons habitually addicted to the use of alcohol, opium, cocaine, morphine, or any other intoxicant, may be committed to an institution for a period of time necessary for complete reformation.

Massachusetts. 4 Ann. Laws (1933) ch. 123, sec. 62. A person "who is subject to dipsomania or inebriety either in public or in private, or who is so addicted to the intemperate use of narcotics, habitforming stimulants or sedatives, as to have lost the power of selfcontrol" may be committed to the state farm, or other designated institution for a period of not more than two years.

Michigan. 2 Comp. Laws ( 1929) sec. 6885. (Mich. Stats. Ann. $\S 14.808$.) Persons "adjudged to be so addicted to the excessive use of intoxicating liquors, or narcotics or noxious drugs, as to be in need of medical or sanitary treatment . . . for whose person a guardian has or may be appointed" may be committed indefinitely.

Mississippi. Code Ann. (1930) ch. 50A, secs. 296, 297. Habitual users of narcotic drugs who endanger the public morals, health, safety, 


\section{THE PREVENTION OF REPEATED CRIME}

or welfare, or persons so far addicted as to have lost the power of self-control with reference to their addiction may be committed to an institution to rehabilitate them and restore them to mental and physical health.

Montana. I Rev. Codes (I935) sec. I 445 ff. Dipsomaniacs and inebriates "who shall have been regularly examined and found of unsound mind as a result of the use of any such intoxicant or drug" may be committed to the "state hospital for inebriates" until cured.

New York. 23 McKinney's Consol. Laws Ann. (1938) sec. r39-a (2). A person who is "dangerous to himself or others, by reason of habits of periodical, frequent, or constant drunkenness - . ." may be committed for a period of from one to three years.

North Carolina. Code Ann. (1935) ch. 43, secs. 2284, 2285. Inebriates may be committed to the state hospital for treatment and cure. An inebriate is defined as "Any person who habitually . . . indulges in the use of intoxicating liquors, narcotics or drugs to such an extent as to stupefy his mind and to render him incompetent to transact ordinary business with safety to his estate, or who renders himself, by reason of the use of intoxicating liquors, . . . dangerous to person or property, or . . . cruel and intolerable to his family . . "

Oregon. 3 Comp. Laws Ann. (1940) sec. 24-636. An habitual user of narcotic drugs is deemed a vagrant and on conviction shall be punished as for vagrancy (sec. 23-I 3 II).

Pennsylvania. Purdon's Stats. Ann. (1938) tit. 50, sec. 9 I I. Persons so addicted to intoxicating liquor as to be in need of restraint, care, and treatment may be committed on application of wife, husband, child, etc.

Tennessee. Michie's Code Ann. (1938) sec. 4783 ff. Inebriates, dipsomaniacs, and drug habitués may be committed in the same way as persons of unsound mind to institutions for their detention and treatment. A commitment is not to exceed two years.

Vermont. Laws ( 1934) No. I, sec. 67. "A person who, within a period of one year, has been three times convicted of being found intoxicated shall, if the court . . . so orders, be taken 
for treatment at the expense of the state to the state hospital for the insane until further order of the court."

Virginia. Code (I942) sec. 1068. "Any person who through use of alcoholic liquors or habit-forming drugs, has become dangerous to the public or himself, and unable to care for himself or his property or family, and for either of these reasons has become a burden on the public" shall, if found in the above condition, be committed to a state hospital for the insane "to be kept and held there until the superintendent of that institution shall declare such person cured and restored to his normal condition.

Washington. 4 Remington's Rev. Stats. Ann. (1932) sec. 2509-6. Health officers are empowered to make examination of persons reasonably believed to be habitual users of narcotics, and to require such persons to report for treatment to an approved physician, and to continue treatment at their own expense until cured, or to submit to treatment, provided at public expense, until cured, "and also to isolate or quarantine habitual users of such narcotic drugs or their derivatives. . . . Provided, that such habitual users shall not be isolated or quarantined until the state board of health shall first, by general regulation, determine that the quarantine or isolation of all habitual users is necessary."

Sec. 2509-7. Prison authorities of any state, county, or city prison are directed to make available to the health authorities such portion of their prisons as necessary for a clinic or hospital "wherein all persons who may be confined or imprisoned in any such prison, and who are habitual users of said drugs or their derivatives, may be isolated and treated at public expense until cured, or in lieu of such isolation - . ." must report to own physician, etc.

Vol. Io, secs. 10242-I ff. establish a state narcotic farm colony.

$W$ isconsin. Stats. (1941) sec. 161.28. Drug addicts may be committed to an institution for the treatment of drug addicts for not less than six months, or until cured of their addiction, but not exceeding one year. 


\section{Appendix F}

\section{Limitation of Market for Prison-made Goods}

$7 \mathrm{HE}$ majority of jurisdictions forbid sale on the open market of prison-made goods, either absolutely and

1 without exception, as in Arizona and Idaho, or to a limited extent. These limited restrictions vary widely. Iowa, for example, merely requires prison-made goods to be labeled as such; Kansas permits sale of tags, markers, twine and agricultural products; Massachusetts permits retail sale at the institution; New Mexico prohibits sale of such goods from other states, but allows its own to be sold by public advertisement and bid; Wisconsin provides that "no monumental articles" shall be sold. In general, however, the restrictions on open marketing are sufficient to limit seriously the development of education of convicts in trade skills if no other opportunity for disposal of products were provided.

Arizona. 3 Code Ann. (1939) sec. 47-301. No products of prison labor may be sold or exchanged on the open market within the state.

Arkansas. Digest of Stats. (1937) sec. 12777. It is unlawful to use, possess, store, sell, or distribute goods produced in whole or in part by convict labor.

California. Penal Code (1941) secs. 2709, 2870. Prison-made products must be so labeled and cannot be sold nor given away for private use.

Colorado. 4 Stats. Ann. (1935) ch. 131, secs. 107, 108. The sale, use, or storage of prison-made goods is unlawful except by some governmental unit or public institution. The rule applies to convictmade goods from other states as well as to those made in Colorado.

Connecticut. Gen. Stats. (I 939 supp.) sec. I448e. It is unlawful to sell for purposes of resale. 
Florida. Stats. ( I 94I) secs. 959.02, 959.03. It is a misdemeanor for any person or any federal authority, state or political subdivision thereof to sell or offer for sale in this state "goods, wares or merchandise manufactured or mined, in whole or in part by convicts or prisoners (except convicts or prisoners on parole or probation). . . ."

Georgia. Laws (1939) p. 108, sec. 7. The prison and parole commission can "establish such industry and manufacture such products as are permitted by law," but is not authorized to set up any "business, whether industrial or agricultural, for sale of such products to the public in competition with private industries or agricultural activities. . . ." But see Code Ann. (I933) sec. 77323 , which indicates that prison-made goods can be sold to the public by the state itself.

Idaho. I Code Ann. ( I 932) sec. 20-407. "So far as practicable, no article shall be manufactured with convict labor which is extensively manufactured in the state of Idaho.

Sec. 20-70I. Sale of prison-made goods or of prison-mined goods on the open market is prohibited.

Illinois. Ann. Stats. (1935) ch. 108, sec. 75. (Jones Ann. Stats. 99.053.) Convict-made goods may not be sold on the open market nor in competition with the products of free labor.

Indiana. 4 Stats. Ann. (I933) sec. Io-4923. Convict-made goods may not be offered for sale on the open market, though they may be sold privately for personal use without resale.

Iowa. Code (1939) sec. 3274.I. Prison-made goods must be labeled as such.

Kansas. Gen. Stats. Ann. (1935) sec. 76-2466. Declares by implication, that only tags, markers, twine, or agricultural products may be sold on the open market.

Louisiana. Code of Crim. Proc. (1932) art. 1322. "No goods, wares or merchandise manufactured, in whole or in part, out of leather, iron, textiles, lumber or vegetable fibre, by convicts or prisoners (except convicts or prisoners on parole or probation) in the state of Louisiana, or in any state or district of the United States, shall be sold or offered for sale in this state. . . ." 


\section{THE PREVENTION OF REPEATED CRIME}

\section{Maryland. Ann. Code (1939) art. 27, sec. 762(I). "No goods}

- . . manufactured by convicts or prisoners in the State of Maryland or elsewhere . . . shall be sold in this State except by or for the State of Maryland . . . and in no event either directly or indirectly to the consuming public, except that perishable vegetables may be sold to canneries. . . ."

Massachusetts. 4 Ann. Laws (1933) ch. 127 , sec. $67 \mathrm{ff}$. It is unlawful to sell convict-made goods unless sold at retail on the premises of the institution where they were made or unless sold to the Commonwealth or to any political subdivision thereof, or to certain other institutions.

Michigan. 3 Comp. Laws (1929) sec. 17636-5. (Mich. Stats. Ann. $\$ 28.1525$.) It is unlawful to sell or exchange or to purchase any prison products except pure-bred livestock raised on the several prison farms and sold for breeding purposes. This does not apply to articles made by prisoners for their personal benefit or that of their dependents, or to binder rope and cordage used in agricultural production or to sales to state institutions.

Minnesota. 3 Mason's Stats. (1927) sec. 10846-21. Prohibits goods produced or mined by convicts to be bartered, traded, or exchanged by penal institutions for any goods of any kind for use in such institutions.

Sec. 3976-31. It is unlawful to sell prison-made goods unless so marked.

Mississippi. Gen. Laws (1940) ch. I37, sec. I. Convictproduced goods may not be offered for sale or exchange on the open market. This does not apply to goods made by convicts on parole or probation, nor to perishable goods and agricultural products, nor to goods made by convicts for their personal benefit, nor to sales to other governmental institutions. Articles so exempted must be marked "prison-made."

Montana. 5 Rev. Codes (1935) sec. I2447.I ff. Wearing apparel manufactured in the state prison may not be sold on the open market in competition with the products of free labor. The board of prison commissioners may sell hides tanned or treated at the prison. 
Brick manufactured at the state prison may be used only for construction or repair of buildings at the state prison.

Sec. II 573.I. No goods manufactured in penal or reformatory institutions may be sold on the open market.

Nebraska. Comp. Stats. (1929) sec. 83-966. The sale of prison made goods, except those made by convicts or prisoners on parole or probation, is prohibited unless the sale is specifically sanctioned by law.

New Hampshire. 2 Public Laws (1926) ch. 400, sec. 6. Prison trustees "so far as may be practicable shall dispose of the products of every prison industry under their control and management to public institutions within the state."

Laws (1933) ch. 42, sec. I. No goods made by convicts shall be sold on the open market.

New Jersey. I Rev. Stats. (1937) sec. 30:4-97. Surplus products of convict labor may be sold in the open market under such terms as not to compete unfairly with free labor. All goods made by convict labor must be so marked.

New Mexico. Stats. Ann. (1941) sec. 45-149. Prison-made goods must be so labeled, unless made by a prisoner for his own benefit.

New York. IoB McKinney's Consol. Laws Ann. (1929) ch. 47, sec. I77. Prison-made goods may be sold to state institutions "Provided . . . that no product manufactured . . . in any penal institution . . . shall be sold, or otherwise disposed of for profit, by any officer, or administrative body of the state . . . except to the state itself or a political subdivision thereof, or to or for a public institution . . .; and in no case shall said products be purchased for resale. . . ."

North Carolina. Code Ann. (1935) sec. 4468 (a). “. . . the sale anywhere within the state of North Carolina of any and all goods, wares and merchandise manufactured, produced or mined wholly or in part, by convicts or prisoners . . . is hereby prohibited and declared unlawful. . . ."

Ohio. Throckmorton's Code Ann. (1940) sec. 2228-1. Convictmade goods may not be sold on the open market. 
Oklahoma. Stats. (I94I) tit. 74, sec. I23f. The sale of goods manufactured by prisoners, except prisoners on parole or probation, is prohibited except that if the departments or institutions of the state do not buy the products, the state may sell on the open market such goods as are not generally manufactured in Oklahoma.

Tit. 74 , sec. 123 a forbids the manufacture by prison labor of products generally manufactured by private industry in the state.

Oregon. 8 Comp. Laws Ann. (1940) sec. 127-1004. Sale of prison-made goods on open market is prohibited with the exception of flax processed by prisoners.

Sec, 127-IO12. All goods made by convict labor in any prison must be clearly labeled or branded as such.

Pennsylvania. Purdon's Stats. Ann. (1930) tit. 6I, sec. $25 \mathrm{I}$. All goods made by convict labor, "whether for the direct benefit and maintenance of such penitentiary, reformatory prison, school or other establishment, or upon contract by the authorities of the same with any third person," must be branded as convict-made.

Sec. 252. The brand shall be the words "convict made", followed by the year and the name of the penitentiary in which the article was made. "Provided, That goods, wares and merchandise shipped to points outside of the state shall not be so branded."

Rhode Island. Gen. Laws (1938) ch. 64, sec. 3. Sale on open market of prison-made goods is prohibited.

Tennessee. Michie's Code Ann. (1938) sec. 12206 (3). "In order that any competition between the labor of such convicts to be worked directly by and for the benefit of the state, and free labor, shall be reduced to its practical minimum, all reasonable efforts shall be made to dispose of the articles manufactured by such prisoners at such prices as will best protect the financial interests of the state, and maintain the earnings of such prisoners as nearly as may be on a par with the prices paid to free labor engaged in the same lines of manufacture."

Sec. 12209 (4). "From and after the effective date of this chapter no goods, wares or merchandise manufactured, in whole or in part by convicts or prisoners (except those on parole or probation) shall be sold or offered for sale in this state by any person, firm, association or 
corporation or by any federal authority, state or political subdivision thereof; provided, however, that nothing in this chapter shall be construed to forbid the sale, exchange or disposition of such goods to any institution supported wholly or in part by funds derived from public taxation and operated under the supervision of the United States of America, the state of Tennessee, or any other state of the union, or any political subdivision thereof."

Texas. I7 Vernon's Civil Stats. (1925) art. 6166z8. "No sale of prison made goods in intra state commerce in this State shall ever be valid. . . ." Goods must be labeled with the words "Prison made Goods."

2 Vernon's Penal Code (1925) art. I I37i-I. It shall be a misdemeanor "for any person, firm, partnership, association, or corporation to sell or offer for sale within the State of Texas any goods, wares, or merchandise manufactured wholly or in part by convicts or prisoners in penal or reformatory institutions, except convicts or prisoners on parole or probation. . . ."

Utah. 5 Code Ann. (r 943) sec. 85-9-3r. In determining lines of productive labor to be used in state prison, the board of correction "shall select diversified lines of industry so as to interfere as little as possible with the same lines of industry carried on by citizens of this state."

Sec. $85-9-87$. Forbids sale on open market of convict-made goods. Sec. 85-9-89. Excepts certain goods sold for personal benefit of prisoners.

Sec. 85-9-88. Requires labeling as prison-made goods.

Virginia. Code (1942) sec. 5009b. Sale or exchange of prisonmade goods on open market is unlawful.

Washington. Io Remington's Rev. Stat. Ann. (1932) sec. 10262. The jute grain sacks and other fabrics and products manufactured at the state penitentiary shall be sold directly to the farmers, oyster growers or wool growers of the state of Washington, who are actually engaged in farming, oyster culture and wool growing, and no sacks shall be sold within the state of Washington to any person not engaged in farming or oyster culture and wool growing. But 


\section{4O THE PREVENTION OF REPEATED CRIME}

the state board of control may sell such products on the open market at such prices as best benefit the state, between the first of June and the first of January.

7 Remington's Rev. Stats. Ann. (1932) sec. 5847-r. "The selling, offering, keeping, exposing or displaying for sale on the open market within this state of any goods . . - manufactured - . by convicts or prisoners, except convicts or prisoners on parole or probation, is hereby prohibited."

West Virginia. Code Ann. (1937) sec. 2773 (r). "It shall be unlawful to sell or offer for sale on the open market of this state any article or products manufactured or produced, wholly or in part, in this or any other state, by convicts or prisoners," except convicts on parole or probation.

Wisconsin. Stats. (194I) sec. 56.01. License plates and highway signs may be sold to other states, but "no monumental" (sic) "articles shall be manufactured and sold in the open market."

Sec. 56.22. "No goods, excepting farm machinery, farm implements and tools, cordage rope and ply goods, and binder twine, manufactured wholly or in part by convicts, prisoners . . . shall be offered for sale on the open market," except those already stocked prior to March I, I940.

Wyoming. Rev. Stats. (I93I) sec. 108-816. Articles may be sold on open market, "provided, however, that no materials furnished for the erection of buildings shall be in competition with established local industries."

Federal. $\quad$ I 8 U. S. C. A. sec. 396 a ff. It is unlawful to ship or knowingly to transport in interstate commerce, convict-produced goods, other than those produced for legitimate institutional use. 


\section{Permissible Sale of Prison-made Goods to Other Institutions}

$\mathrm{I}$ NASMUCH as no state appears to have explicitly forbidden purchase of its own prison-made products by tutions constitute a potentially available market even in the absence of statutes, such as follow, which expressly authorize such purchases. Whether or not these other institutions are obligated to furnish such a market is another matter.

Arizona. 3 Code Ann. (1939) sec. 47-304. "Sale upon the open market" prohibited by section 47-30r "shall not include sales or exchanges between any penal or charitable institutions maintained wholly by the state of Arizona or its political subdivisions. . . ."

Arkansas. Digest of Stats. (1937) sec. I2777. It is unlawful to use, possess, sell, convict-made goods, but "nothing herein shall prevent the sale or distribution of such goods by the State Prison Board . . . to the State or any political subdivision thereof, or the tax supported institutions of either." Cotton and other farm products produced on state-owned or state-leased lands are not precluded from general sale.

Colorado. 4 Stats. Ann. (1935) ch. 131, sec. 107. Use, consumption, or sale of convict-produced goods is unlawful except by the state, or its subdivisions, or public institutions.

Connecticut. Gen. Stats. (1939 supp.) sec. 1448e. It is unlawful to use, sell, etc., but nothing herein forbids sale to the state, or a political subdivision, or public institution, or to any person or corporation for its own consumption without resale.

Florida. Stats. (194 I) sec. 959.02. It is unlawful to sell convictmade goods, but the prohibition is not to be construed as forbidding sale to any institution supported in whole or in part by the state or a political subdivision. 


\section{THE PREVENTION OF REPEATED CRIME}

Georgia. Code Ann. (1933) sec. 77-356. Superintendent of state farms has no power to sell prison products, "except for the needs of the state," etc. To the same effect, sec. 77-323.

Sec. 77-332. The prison commission is authorized and directed to manufacture road signs and automobile license tags which are to be sold to the state highway board.

Idaho. I Code Ann. (1932) sec. 20-703. The statutory preclusion of sale of convict-made goods on the open market "shall not include the sale and/or exchange . . . with other penal, charitable and/or custodial institutions the major portion of whose maintenance is contributed by this state. . . ."

Kansas. Gen. Stats. Ann. (1935) sec. 76-2468. Board of administration may sell all products to the state at as near market price as possible.

Sec. 76-2466. Products of prison labor "may be disposed of to the state or for or to any public institution."

Kentucky. Acts Spec. Sess. (1936-1937) p. 133, ch. 16. Sale generally is forbidden, but not sales to the public institutions of the state or its political subdivisions.

Louisiana. Code of Crim. Proc. (1932) art. 1322. Forbids sale of convict-made goods of certain types, but provides that "nothing in this act shall be construed to forbid the sale, exchange, or distribution of such goods to any institution supported in whole or in part by funds derived from public taxation. . . ."

Michigan. 3 Comp. Laws (1929) sec. 17636-8. (Mich. Stats. Ann. $\$ 28.1528$.) The prison commission may contract with other state institutions for prison products, and the state purchasing agent may buy such products, even for exchange for products of prisons in other states.

Mississippi. Gen. Laws (1940) ch. I37, sec. I. Restrictions on sale do not apply to sales to institutions controlled or supported wholly or in part by the state or political subdivisions, or those of other states or the federal government.

Montana. 5 Rev. Codes (1935) sec. I1 573.2. Restrictions on sale do not apply to sales to other state institutions or those of political subdivisions. 
New Hampshire. Rev. Laws (1942) ch. 464, sec. 6. Prison trustees so far as practicable shall dispose of prison products to state institutions.

New Mexico. Stats. Ann. (194I) 4I-3309. The sale of prisonmade goods manufactured in another state is prohibited, but this shall not be construed "to forbid the sale of such goods to the State or any political subdivision thereof, or to any public institution. . . ."

New York. IoB McKinney's Consol. Laws Ann. (1938) sec. 170. Convicts in penal institutions may work for, and their products be disposed of to, the state and the political subdivisions thereof.

North Carolina. Code Ann. (1935) sec. 7762 . Prison products may be disposed of to any public institution owned, managed, or controlled by the state or any county, city, or town.

North Dakota. Comp. Laws (1913) sec. 11270. Prison products may be sold to make needed repairs, additions, or improvements to the public buildings of the state. Surplus brick may be disposed of to private purchasers. Laws (1933) ch. 242. Coffins made at the penitentiary may be sold to state or private purchasers.

Ohio. Throckmorton's Code Ann. (1940) sec. 2230. Prison labor may be used for supplies of institutions of the state or political subdivisions.

Pennsylvania. 7I Purdon's Stats. Ann. (1930) sec. 602. It is the duty of the department of welfare to sell the articles which cannot be used by the penal institution that manufactures them to other institutions or departments of the state.

Rhode Island. Gen. Laws (1938) ch. 64, sec. 5. The prohibition of the sale of convict-made goods shall not include their sale or exchange to or with other reformatory or custodial institutions or to any other department, institution, or agency of the state.

Tennessee. Michie's Code Ann. (1938) sec. 12209 (4). "No goods, wares or merchandise manufactured, in whole or in part by convicts or prisoners (except those on parole or probation) shall be sold or offered for sale in this state by any person, firm, association or corporation or by any federal authority, state or political subdivision thereof; provided, however, that nothing in this chapter shall be con- 
strued to forbid the sale, exchange or disposition of such goods to any institution supported wholly or in part by funds derived from public taxation and operated under the supervision of the United States of America, the state of Tennessee or any other state of the union, or any political subdivision thereof."

Texas. 2 Vernon's Penal Code (1925) art. I $137^{\mathrm{i}-1 .}$. Nothing shall be construed to prohibit the sale of prison-made goods "to the State, or to any political subdivision thereof, or to any public institution owned or managed and controlled by the State or any subdivision thereof."

Utah. 5 Code Ann. (1943) sec. 85-9-32. The board of correction shall employ "as many prisoners as are necessary in making articles for the various state departments and institutions, as far as practicable, who shall pay the market price of all articles furnished."

Sec. $85-9-89$. Prohibition of sale on open market does not apply to sales to state institutions.

Vermont. Laws (1937) No. 165, sec. 5490. The commissioner "may contract with the motor vehicle, highway and any other de-" partment or agency of the state for the manufacture of motor vehicle number plates, road and highway signs or other plates, signs or products required by said departments and agencies. Such departments and agencies shall give preference to such prison made goods when deemed for the interest of the state in the solution of its prison labor problems."

Washington. Io Remington's Rev. Stats. Ann. (1932) sec. 1022I. All convicts may be employed by authority of the board, under charge of the superintendent and such skilled foremen as necessary in performance of work for the state, or manufacture of articles for the state, or the manufacture of which is sanctioned by law. At the state penitentiary no articles shall be manufactured for sale, except jute fabrics and brick. In this connection the board is authorized to purchase and employ and dispose of articles manufactured and not needed by state, for cash, at private sale, as provided by law.

7 Remington's Rev. Stats. Ann. (1932) sec. 5847-1. This act shall not prohibit the sale to or exchange between penal 
- . institutions and/or departments of this state for use or consumption by said institutions, of goods . . manufactured - . by convicts or prisoners of the state of Washington. . . ."

Wyoming. Rev. Stats. (1931) sec. 108-816. ". . . All articles manufactured at the state penitentiary and not required for use therein, may be furnished to the state or for or to any public institution owned or managed and controlled by the state, or for use on any roads or highways under the direction of the state highway commission.

District of Columbia. Code (1940) sec. 24-418. Brooms made by the inmates of the reformatory may be sold to the various branches of the government of the District of Columbia.

42 Acts of Congress affecting the District of Columbia 473; Public Act No. 602, 76th Congress, ch. 333, 3d Session. Appropriation of $\$ 30,000$ for industrial enterprises for the workhouse and reformatory: "Provided, That the various departments and institutions of the District of Columbia and the Federal Government may purchase, at fair market prices, . . . such products and services as meet their requirements. . . ."

42 Acts of Congress affecting the District of Columbia 9 I 5 ; Public Act No. 85 r, 76th Congress, ch. 872, 3d Session. The transportation of convict-made goods in interstate commerce is unlawful: "Provided, That nothing herein shall apply to commodities manufactured in Federal or District of Columbia penal and correctional institutions for use by the Federal Government. . . ."

Federal. 3 I U. S. C. A. sec. 686. Executive departments and independent establishments of the Government may purchase necessary supplies from other Federal agencies. But these sections shall not be construed to authorize purchase of convict-produced goods except as otherwise provided by law. (18 U. S. C. A. sec. $744 \mathrm{~g}$ requires such purchase under certain restrictions.) 


\section{Appendix $\mathrm{H}$}

\section{Requirement of Purchase of Prison-made Goods by Other Institutions}

7 HOUGH in many states where sale of prison-made goods on the open market is forbidden the market-

1 ability of such products to other state institutions is permissible only and depends upon the willingness of those other institutions to purchase, in a majority of states the statutes now require institutions maintained or supported by the state to purchase from the prisons such of their necessities as the latter are able to supply. Though the phrasing of these statutes varies somewhat, they seem in general adequate to furnish a market for a wide variety of trade-skill training in the penitentiaries.

Arkansas. Digest of Stats. (1937) sec. 12667. It is the duty of state institutions "so far as possible" to buy the produce of state penal farms.

California. Penal Code (1941) sec. 2873. All articles authorizedly produced in state prisons must be purchased by the state for public use.

Colorado. 4 Stats. Ann. (1935) ch. 13I, sec. 97. The state must buy prison-made goods which are needed.

Idaho. I Code Ann. (1932) sec. 20-708; Laws (194I) ch. 120, p. 242. State institutions must buy products of prisons in order to carry out the purpose and intent of the prison labor act.

Illinois. Rev. Stats. (1935) ch. 108, sec. 86. (Jones Ann. Stats. 99.067.) State institutions must purchase from prison industries if possible.

Indiana. 4 Stats. Ann. (1933) sec. 13-102. "The state, its institutions, except those which produce similar articles, and the political 
divisions of the state using such articles as may be produced (in the state prisons, etc.) . . . shall be required to purchase such articles at a price fixed by the board of classifications of industries.

Iowa. Code (1939) sec. $3760 \mathrm{ff.} \mathrm{"Boards} \mathrm{of} \mathrm{supervisors,} \mathrm{boards}$ of school directors, city and town councils and commissions, township trustees" as well as state institutions must supply their needs from prison products to the extent available.

Kansas. Gen. Stats. Ann. (1935) sec. 76-2514. ". . . The products of the labor which are not used for the women's industrial farm shall be used in other institutions in the state, and a system of bookkeeping shall be had between the various institutions using such products and the industrial farm for women. . . ."

Kentucky. Carroll's Stats. (I930) sec. $3828 c-5$. It is the duty of all state departments to purchase supplies from the prison industries to the extent that they are so available.

Maryland. Ann. Code (1939) art. 27, sec. 762 (3). All state institutions receiving at least 50 per cent of their funds from the state must purchase what they need from the board of correction unless notified that the latter cannot furnish the articles required.

Massachusetts. 4 Ann. Laws (1933) ch. I27, sec. 53. The commissioner shall, so far as possible, cause such articles and materials as are used in the offices, departments or institutions of the commonwealth and of the several counties, cities, and towns, to be produced by labor of prisoners.

Sec. 57. Articles produced by penal or reformatory institutions must be purchased by state and political subdivisions.

Michigan. 3 Comp. Laws (1929) sec. 17636-7. (Mich. Stats. Ann. $\$ 28.1527$.$) State purchasing agent shall requisition what is$ needed for state institutions and departments from the prisons, to the extent that the prisons are able to supply what is needed. It is the duty of the prison authorities to produce as much of such needs as possible.

Minnesota. 4 Mason's Stats. (I927) sec. 53-18B (19). The commissioner of administration of the state is required to purchase from 


\section{THE PREVENTION OF REPEATED CRIME}

the state penal institutions and other state institutions all articles manufactured by them which are usable by the state.

Missouri. 2 Rev. Stats. (1939) sec. 8990. The state and its political subdivisions are to purchase articles manufactured in penal institutions to the extent needed.

Montana. 5 Rev. Codes (1935) sec. I 2447.I. All wearing apparel manufactured at state prison and not required for its own use "shall be sold to the state for use by the state in any of the public institutions owned or managed or controlled by the state." The implication seems to be an obligation on the latter institutions to buy.

Nebraska. Comp. Stats. (I929) sec. 83-957. All agencies of the state are required to purchase articles required by them which are produced or manufactured by convicts.

Sec. $83^{-1}$ 36. All license number plates must be manufactured in the state penitentiary or reformatory.

Nevada. 3 Comp. Laws (1929) sec. 7076. Provides for the purchase of products of state institutions by other state institutions and the method of payment.

New Hampshire. Rev. Laws (1942) ch. 464, sec. 33. "No articles or supplies such as are manufactured at the state prison by the labor of convicts shall be purchased from any other source for the state or its departments or institutions unless the superintendent of industries shall first certify that the state prison cannot furnish them." .

New Jersey. I Rev. Stats. (1937) sec. 30:4-95. State institutions must purchase from state board all articles or supplies manufactured or produced by institutional labor which are needed by them.

New York. IoB McKinney's Consol. Laws Ann. (I 938) sec. 184. Articles needed by state institutions must be purchased, if possible, from penal institutions.

Oklahoma. Stats. (I941) tit. 74, sec. 123a. "All departments, institutions and agencies of this State . . . shall obtain such goods, wares, merchandise or products as they may from time to time require, exclusively from the State Board of Public Affairs . . ." which establishes industries in penal institutions (sec. 123).

Oregon. 8 Comp. Laws Ann. (1940) sec. 127-1009. Oregon state board of control and the managements of state charitable and 
penal institutions "shall jointly annually effect such rules and regulations as may be necessary to carry out the purpose and intent of this act, to wit: the purchase by said institutions of the products to be manufactured in the penal and/or reformatory institutions of this state."

Rhode 1sland. Gen. Laws (1938) ch. 64, sec. 7. When state purchasing agent or head of any city, department, or institution shall need any goods similar to those manufactured at the prison, he shall requisition the same from the department of public welfare. "If said articles or materials are needed immediately and are not on hand, the said department shall forthwith notify the requisitioner, and he may purchase elsewhere."

South Carolina. 3 Code of Laws (1942) sec. 5892. All license plates and road signs shall be bought by the state highway department from the state penitentiary, and the prices charged "shall be in line with prices heretofore paid private manufacturers."

Sec. 3079-4. All penal institutions shall purchase "all strips, overalls, shirts or any other clothing" from the state penitentiary, at a price not greater than can be bought elsewhere.

South Dakota. Code (1939) sec. 55.1708. The state department must buy license plates and markers from the penitentiary.

Tennessee. Michie's Code Ann. (1938) sec. 12209. "The department of finance and taxation is authorized and directed to contract for and purchase from the department of institutions the requirements of the state of automobile number plates, to be paid for as if purchased from some individual dealer. . . ."

Texas. 17 Vernon's Civil Stats. (1925) art. 6203g. ". . . The Penitentiary System will grow, produce and sell farm products to the various State Institutions at a price not to exceed the lowest bid which the Board of Control may receive from competitive bidders for the various products grown and offered for sale by the Penitentiary System of Texas."

Virginia. Code (1942) sec. 2073a. All departments of the state shall purchase their required articles from the penitentiary, or penitentiary farms unless "the article so produced or manufactured does not meet the reasonable requirements of such department, institution, or agency of the State." 


\section{I50 THE PREVENTION OF REPEATED CRIME}

West Virginia. Code Ann. (1937) sec. 2773(g). State required to purchase all products manufactured at the prison.

Federal. I 8 U. S. C. A. sec. 744g. "The several Federal departments and independent establishments and all other Government institutions of the United States shall purchase at not to exceed current market prices" such available products of the Federal prisons as they need. 


\section{Appendix I}

\section{Authorization of the Establishment of Rehabilitative Industries}

$\longrightarrow \mathrm{HE}$ legislation authorizing establishment of industrial activities varies greatly. Some of it is broad

Lenough to permit practically anything desirable for education in trade skills, as for example the Illinois provision that prisoners may be employed "so far as practicable in occupations in which they will be most likely to obtain employment after their discharge." So also the Indiana statute specifies such "mechanical arts," "trades and handicrafts" as will enable the inmates of "reformatories" to become self-supporting. The lowa statute is likewise an apparent grant of broad authority. The Alabama and Minnesota statutes provide that prisoners shall be employed in such industries as the proper officials see fit to establish. In other states the expressed authorization is more limited, and in Delaware there appears to be no clear statutory authorization of prison industries but, on the other hand, nothing to preclude their establishment.

In some of the statutes the purpose of the industry to be established is clearly expressed as rehabilitative. Thus in North Carolina prisoners are to be employed so far as practicable "on the work to which they are best adapted and which will make it possible for them to improve and acquire greater skill that they may earn a livelihood when paroled or discharged." In New Jersey, on the other hand, the expression is a colorless "shall be employed in such productive occupations as are consistent with their health, strength and mental capacity." In still other statutes the provision seems merely one of providing occupation rather than idleness. But in gen- 


\section{THE PREVENTION OF REPEATED CRIME}

eral it seems clear that there is ample statutory authority for the development of rehabilitative industries in the prisons and reformatories if the will to establish them is sufficient and if the necessary funds are obtainable. In this latter connection the Michigan statute is outstanding, though unique only in the amount stated, in establishing a revolving fund of $\$ 500$,000 with which to purchase equipment and supplies.

Alabama. Code (1940) tit. 45, sec. 28. "The state convicts shall be employed at such labor and in such places and under such regulations within the state as may be determined by the director, with the approval of the governor."

Arizona. Code Ann. (1939) sec. 47-108. "The board shall require of every able-bodied convict as many hours of faithful labor in each day, during his term of imprisonment, as shall be prescribed in the rules of the prison."

Arkansas. Digest of Stats. (1937) sec. 12657. The board of penal institutions may establish in any state institution "such industries and factories as they may deem to be to the best interest of the State and the welfare of the convicts confined therein."

Sec. 12678 provides for factories where risks are not unduly hazardous and such as will provide "healthful employment such as for manufacture of cotton goods, furniture, brick, twine," etc.

California. Penal Code (194r) sec. 270r. The board of prison directors is authorized to produce in the prisons "such articles, materials and supplies as are now, or may hereafter be, needed by the State, or any political subdivision thereof" or for use in school or public institutions.

Sec. 2707. The board is empowered "to purchase, install, and equip, such machinery, tools, supplies, materials, and equipment as may be necessary."

Colorado. 4 Stats. Ann. (1935) ch. 131, sec. 94. The board of corrections can employ prisoners to manufacture, produce, or mine goods for state departments and institutions.

Connecticut. Gen. Stats. (1930) sec. 2017. County commissioners "may require all convicts in jails or workhouses to work ac- 
cording to their ability." There appears to be no similar provision concerning state prisons, but certain contracts for the labor of convicts are permitted by sec. 1980 .

Delaware. Rev. Code (I935) 4I45, sec. 28. Prisoners "shall be compelled to labor at some suitable employment eight hours each secular day unless physically disabled."

Florida. Gen. Laws Ann. (1927) sec. 8663. The board of commissioners is authorized to set up industrial plants in all state institutions, "in a manner profitable to the State of Florida and of benefit to the inmates of such institutions."

Georgia. Laws (1939) p. 108, sec. 7. Prison and parole commission can "establish such industry and manufacture such products as are permitted by law."

Idaho. Code Ann. (1941 Supp.) sec. 20-705. The prison board may provide for production of "as wide a variety as possible" of such goods as may be needed in other state institutions, with such diversification and variety of products as to minimize the competition with private industry.

Illinois. Rev. Stats. (1935) ch. 108, secs. 76-85. (Jones Ann. Stats. 99.054-99.066.) Prisoners must work, and shall be employed "so far as practicable in occupations in which they will be most likely to obtain employment after their discharge from imprisonment." The work "shall be directed with reference to fitting the prisoner to maintain himself by honest industry after his discharge."

Indiana. 4 Stats. Ann. (1933) sec. 13-4 I9. "In the employment, education and training of the inmates of the reformatory, the board of managers shall have full power to establish and introduce such trades schools as said board may determine for the training of the inmates in the mechanical arts. . . . Provided, That said reformatory shall not produce any schoolbooks and desks used by pupils for use, or which shall be used, in the common schools of the state.

Sec. 13-420. Provides that profits from such trade schools may be used as working capital. 


\section{I54 THE PREVENTION OF REPEATED CRIME}

Sec. 13-103. A "board of classification of industries" is created "to determine what industries shall be operated in the institutions named in this section, to the end that unnecessary duplication of industries may be avoided. . . ."

Iowa. Code (1939) sec. 3757. Prisoners in penitentiary or men's reformatory may be employed about the buildings "and in such industries as may be established and maintained in connection therewith." Read in connection with provisions concerning the furnishing of articles by the prisons to other institutions, this gives the board of control broad powers.

Sec. 3764 . I. Establishes a revolving fund from sale of prison products for the establishment and maintenance of prison industries.

Sec. 3723 . The purpose of the women's reformatory is to make its inmates self-supporting through practical instruction.

Kansas. Gen. Stats. Ann. (1935) sec. 76-2320. Prisoners "may be employed in such labor as will best contribute to their support and reformation."

Kentucky. Carroll's Stats. (1930) sec. 216a-4. The board of charities and corrections, "having in mind the welfare of the inmates of the several institutions under its control and the interests of the Commonwealth, shall encourage the employment in every proper way of said inmates in such ways as shall contribute to their physical, mental and moral improvement. . ."

Sec. $3828 \mathrm{c}-\mathrm{I}$ ff. The department of public welfare is required "to exhaust every resource at its command to provide employment for all prisoners in its custody, and thereby to raise revenue for the self-support of said prisoners and the state prisons and to prevent idleness, mutiny, and discontent therein." It is authorized to acquire necessary equipment and materials for the manufacture of state supplies and to "establish industrial training in the several state prisons." The sum of $\$ 50,000$ is appropriated as a revolving fund for the purpose.

Louisiana. Code of Crim. Proc. (1932) art. 1437. Board of control may lease or purchase land for establishment of convict farms or factories. 
Sec. I 472 . Inmates of the Louisiana Training Institute shall "receive an educational, moral, industrial and farm training."

Maine. Laws (1933) ch. I, secs. 300, 304. The department in control shall establish "rules and regulations for the instruction and employment" of prisoners "for the purpose of securing their improvement and future welfare."

Maryland. Ann. Code (1939) art. 27, sec. 762 (3). The board of corrections is authorized to equip penal and reformatory institutions with such plant, machinery, etc. as is necessary to supply all goods and produce required by other state institutions.

Sec. 762 (5). The board has power and authority to place prisoners at labor on state works "whenever in the judgment of said Board the same shall be expedient and proper, upon such terms as to it shall seem wise.

Sec. 762 (3). It is the duty of the board to diversify prison industries in such a manner as not to work a hardship on any one particular free industry.

Massachusetts. 4 Ann. Laws (1933) ch. 127, sec. 61. The commissioner of correction and superintendent of the reformatory shall endeavor to establish in the reformatory such industries as will enable prisoners employed therein to learn valuable trades.

Sec. 85. The commissioner of correction may, with their consent, contract to have women in the reformatory employed in domestic service upon such conditions as he considers proper, with reference to their welfare and reformation.

Sec. 5 I ff. The heads of penal and reformatory institutions shall determine the industries to be established in such institutions. Such superintendents and instructors may be employed as are necessary to instruct the prisoners in those industries.

Sec. 62. Limits the number of prisoners who may be employed in the manufacture of particular articles.

Michigan. 3 Comp. Laws (1929) sec. 17636-2. (Mich. Stats. Ann. $\S 28.1522$.) A revolving fund of $\$ 500,000$ is created with which to purchase supplies, equipment, machinery, and materials for prison industry. 


\section{I56 THE PREVENTION OF REPEATED CRIME}

Sec. 17636-6. (Mich. Stats. Ann. § 28.1526.) Prisoners shall be employed in tasks consistent with the penal and reformatory purposes of their imprisonment. They may be put at educational and rehabilitative activities whether productive or socialized, determined on the basis of individual needs and educability.

Secs. I7543-1, I7543-2. (Mich. Stats. Ann. $\$$ 28.1681, 28.1682.) Probation recovery camps may be established at which educational and instructive courses of vocational nature may be given which are "best suited to equip and train the inmates as good citizens."

Minnesota. 2 Mason's Stats. (1927) sec. 10815. Authorizes the manufacture of all kinds of farm machinery and parts thereof and sets up a $\$ 250,000$ revolving fund for that purpose.

2 Mason's Stats. (1927) sec. ro8ro. Prisoners shall be employed in such industries as are from time to time determined by the proper officials and may be employed under the "piece price system" upon materials furnished by private persons. Sec. 10814 limits the number of prisoners who may be employed in a single industry.

Sec. 10829. Inmates of the reformatory shall "be instructed in trades or employments for which they seem best fitted."

Mississippi. I Code Ann. (1930) sec. 1921. "For use of the penitentiary" the superintendent may establish a blacksmith's shop, woodshop for the manufacture of wagons, etc., shoe and harness shop, saw mill and grist mill, brick and tile factory, and a tailoring shop.

Sec. 1923. Female convicts may manufacture clothing for convicts.

Missouri. 2 Rev. Stats. (1939) sec. 8987. The commissioner can let or purchase lands for farming, rock quarries, grazing, or for any or all purposes proper for the employment in useful work of prisoners in the penitentiary and for training them so that they may be of good health and character and competent to earn an honest livelihood.

Sec. 8988. The commission may provide plants, machinery, equipment and material for the manufacture of such articles as are needed in state institutions and for the manufacture of other articles, including shoes, furniture, desks, etc. which can be disposed of upon the open market. 
Sec. 8992. The policy of the commission in the employment of prisoners shall be to train them so that they may be of good health and character and competent to earn an honest livelihood.

Sec. 9119. The department of penal institutions is to provide for teaching inmates of the intermediate reformatories in profitable and useful trades and to offer such employment in industries, agriculture, and other vocations as will enable them upon their release to more surely earn their own support and be self-reliant and self-supporting citizens.

Montana. 5 Rev. Codes (1935) sec. 12446. The board may cause prisoners to be employed in any mechanical pursuit and furnish them with material necessary therefor and may generally employ them in such manner as will best serve the interests of the state and the welfare of the prisoners.

Sec. II 573.4. The occupation of prisoners is to be diversified so as not to concentrate in any industry.

Nebraska. Comp. Stats. (1929) sec. 83-1012. The board of control of the reformatory for boys has power to engage in such trade and business, including manufacturing and farming enterprise as it may deem for the best interests of the state and for the advancement and reformation and instruction of the prisoners in useful trades.

Sec. 83-1 102. Boys committed to the boys' industrial school 'shall be instructed in the principles of morality and in such useful branches of knowledge as are taught in the public schools of the state. They shall also be instructed in the principles of the mechanical arts and such practical trades as are best suited to their age, strength, and capacity, and best adapted to secure them a livelihood after leaving the school."

Sec. 83-1202. Girls in the industrial school are to be trained in domestic duties and light practical industries.

Sec. 83-1406. In the reformatory for women, "employment of such women shall be for the purpose of teaching them a useful trade or profession and improving their physical, mental and moral condition."

Sec. $83^{-1} 302$. The object of this institution is, among other things, to furnish the inmates "domestic, industrial and other training 


\section{THE PREVENTION OF REPEATED CRIME}

to fit them for self-support; to procure them appropriate employment."

Nevada. Comp. Laws (1929) sec. I1458. The board of commissioners may cause prisoners "to be employed in any mechanical pursuits, and at hard labor, and may furnish such convicts thus employed with any material that may be deemed necessary," and may employ prisoners "in such manner . . . as will best subserve the interest of the state and welfare of the prisoners."

New Hampshire. Rev. Laws (1942) ch. 464, sec. 31. Prohibits contracting of prison labor or products, ". . . except that convicts may work for, and the products of their labor may be disposed of to, the state or any political subdivision thereof, or for or to any public institution."

New Jersey. I Rev. Stats. (1937) sec. 30:4-92. "The inmates of all correctional . . . institutions within the jurisdiction of the state board shall be employed in such productive occupations as are consistent with their health, strength and mental capacity."

New Mexico. Stats. Ann. (194I) sec. 42-I705. It is the duty of the prison board to adopt such rules concerning prisoners committed to their custody as will prevent them from returning to their criminal courses, best secure their self-support, and accomplish their reformation.

New York. IoB McKinney's Consol. Laws Ann. (1938) sec. 171. Prisoners are to be employed "for the purpose of industrial training and instruction."

Sec. 183. It is the duty of the commissioner "to employ the prisoners, so far as practicable, in occupations in which they will be most likely to obtain employment after their discharge from imprisonment."

North Carolina. Code Ann. (I935) sec. 7707. The board has power to provide for employment of all prisoners, either in prisons or farms owned or leased by the state, or elsewhere upon just and fair terms. Sec. 7712 (a) provides for manufacture by prisoners of automobile license plates. Sec. 7712 (b) provides for a shoe factory in the central prison to provide shoes for inmates of various state in- 
stitutions. Sec. 7758 makes it lawful to contract for the employment of convicts on highways or streets.

North Dakota. Comp. Laws (1913) sec. II26I. The prisoner is to be employed so far as practicable "on the work to which he is best adapted and which will make it possible for him to improve and acquire greater skill that he may earn a livelihood when paroled or discharged from the institution." Sec. I I 270 provides for employment in the manufacture of brick. The laws of 1933 provide for a tannery at the penitentiary, for coffins to be manufactured at the penitentiary, and for license plates to be there manufactured.

Ohio. 'Throckmorton's Code Ann. (1940) sec. 2137. The superintendent of the reformatory for men may spend not more than 50 per cent of its gross earnings for equipment and maintenance of industrial training schools. These schools are to be so conducted that the inmates will be taught and trained in various arts of such character as to enable them to perform the skilled labor required at the reformatory and fit them for self-support when released therefrom.

Sec. 2I 48-12. The department of public welfare is authorized to establish educational and vocational schools at the reformatory for women wherein the inmates may be instructed "in educational and vocational lines of such character as may be required to fit them for self-support upon being released from the institution."

Sec. I835-I. "The London prison farm shall be used for the better class of prisoners and devoted to the reformation and the industrial and vocational training of this class."

Oklahoma. Stats. (I94I) tit. 57, sec. 132. “. . . Said board (of Public Affairs) shall have the authority to install and equip such business enterprises, occupations, factories, manufactories, farming and any other business not prohibited by the Constitution, as will employ the inmates of said institutions, and may employ such persons as are necessary for the construction and operation of any building, factory, shop, business or enterprise connected with said institutions. . . ."

Sec. 251. Authorizes establishment of a binder twine plant at the state prison. 
Sec. 26I. Authorizes farm implement factory at the state penitentiary.

Sec. 321 . Tannery and harness and shoe factory are authorized at the state reformatory.

Oregon. 8. Comp. Laws Ann. (1940) sec. 127-1007. Oregon state board of control is authorized to install manufacturing plants to make such goods as may be needed by other state charitable and penal institutions. They shall manufacture "as wide a variety of products as is practicable."

Pennsylvania. Purdon's Stats. Ann. (1930) tit. 6r, sec. 48 r. All male criminals between the ages of fifteen and twenty-five shall be committed to the Huntingdon Reformatory.

Sec. 482. This section limits the inmates between the above ages, to first offenders.

Sec. 5II. The purpose of the reformatory is "to prevent young first offenders . . . from becoming criminals, and to subject them while in custody in this reformatory to such remedial, preventative treatment, training and instruction as may make them honest, reputable citizens." Inmates are to be instructed "in the rudiments of an English education, and in such manual, handicraft, skilled vocations as may be useful to each of the inmates after his discharge from the reformatory, whereby said person will be able to obtain self-supporting employment."

Tit. 71, sec. 602. The department of welfare shall have the power to establish and maintain industries in the penitentiaries and reformatories. Such industries shall be for the purpose of "printing, or of manufacturing and producing supplies, or for the preparation and manufacture of building material for the construction or repair of any State institution . . . manufacture and production of crushed stone, brick, tile and culvert pipe," or other things used in road building by the state.

Rhode Island. Gen. Laws (1938) ch. 64, sec. 6. "The department of public welfare shall cause such articles and materials as are used in the offices, departments or institutions of the state and of the several cities and towns to be produced by the labor of inmates in the public welfare institutions. 
South Carolina. 3 Code of Laws (1942) sec. 5892 . The penitentiary is authorized to establish a plant for manufacturing license plates and metal road signs.

South Dakota. Code (1939) sec. 13.4801. A twine plant revolving fund "shall be maintained . . . for the purpose of conducting the business of the Hard Fiber Twine and Cordage Plant at the State Penitentiary."

Sec. 55.1707. Penitentiary manufactures license plates and highway signs and other markers.

Tennessee. Michie's Code Ann. (1938) sec. 12205. "The commissioner of institutions, with the approval of the governor, is authorized and directed to employ and work at manufacturing articles of merchandise, in shops to be wholly controlled by such commissioner, such of the convicts as in his judgment it will not be safe, humane, practicable, or desirable to work outside the prison walls, that is, such prisoners as cannot with profit to the state, safety to the prisoners and the public be maintained and employed outside the prison walls, it being the purpose and intention of this law to reduce to a minimum the number of prisoners engaged in the manufacturing business in competition with free labor and manufacturers engaged in like business. . . ."

Sec. 12207 . The department of institutions is authorized to manufacture automobile plates, and "kindred articles" at the penitentiary to supply the requirements of the state.

Texas. I 7 Vernon's Civil Stats. (1925) art. 6166a. All prisoners shall "be given opportunity, encouragement and training in the matter of reformation. All prisoners shall be worked within the prison walls and upon farms owned or leased by the State; and in no event shall the labor of a prisoner be sold to any contractor or lessee. . . ."

Art. 6203c-Sec. I. The board shall conduct prison farm units so that the prisoners may be "gainfully employed" in work that will be "remunerative to the State and beneficial to the prisoners."

Art. $6203 \mathrm{c}-\mathrm{Sec} .2 \mathrm{C}$. The board is directed to "install emergency mechanical devices, equipment, and machinery for shops and indus- 


\section{THE PREVENTION OF REPEATED CRIME}

tries now operated or that may be operated profitably in said Central Unit."

Utah. 5 Code Ann. (1 943) sec. 85-9-29. The warden can employ prisoners in "erection or repair of the buildings or walls of the prison, and in the operation and maintenance of the prison."

Sec. 85-9-31. The board of correction shall determine "what lines of productive labor shall be pursued in the prison . . ." but for the purpose of competing as little as possible with private industry.

Vermont. Laws (1937) no. 165, sec. 5490. Commissioner may contract to any person or corporation, the labor of any prisoner for a period not to exceed five years. "He may purchase the material, supplies, machinery and appliances required for employing the convicts, and may employ all necessary superintendents, accountants and other help necessary for such enterprise. - . . He may conduct such manufacturing business as a financial enterprise, separate from the state prison, house of correction and women's reformatory."

Virginia. Code (1942) sec. 5009. "The convicts shall be kept to the hardest labor suitable to their sex and fitness, and such of them, as need it, instructed in some mechanical art."

Sec. 2073. Persons confined in the penitentiary or on state farms shall be used so far as possible in the making of articles required by state institutions.

Washington. Io Remington's Rev. Stats. Ann. (1932) sec. $10257 \mathrm{ff}$. Prisoners may be employed in the manufacture of jute fabrics, brick, and crushed stone. A revolving fund of $\$ 50,000$ is set up for the purpose.

Sec. 10280-7. Prisoners in the reformatory may be required to work "in such manner as may be prescribed by the director of business control."

West Virginia. Code Ann. (1937) sec. 2773 (f). The board of control is authorized to purchase "equipment, raw materials and supplies and to engage the supervisory personnel necessary to establish and maintain for this state at the penitentiary or any penal farm or institution now or hereafter under control of this board, industries for the utilization of services of convicts in the manufacture or production of such articles or products as may be needed for the construction, opera- 
tion, maintenance or use of any office, department, institution or agency supported in whole or in part by this state and the political subdivisions thereof."

Wisconsin. Stats. (1941) sec. 56.01. The state board of control may conduct various industries including the manufacture of license plates and highway signs. The board may lease or purchase lands for farming, limestone beds for the manufacture of fertilizer, and rock beds for road building materials.

Sec. 56.02. The board of control shall maintain a binder twine plant.

Sec. 54.0 I (4). "Farming, forestry, quarrying" may, by implication, be carried on at the reformatory.

Sec. 56.07. "State board of control may maintain in the state reformatory a manual training school, and cause the inmates to be instructed in trades. . . ."

Wyoming. Rev. Stats. (1931) sec. 108-814. The board of charities and reform and warden shall direct that convicts shall be employed at such work as shall make it possible for them to acquire trade knowledge and skill in the industry for which they are most adapted, and at which they can best earn a livelihood when paroled or discharged.

Sec. 108-816. Wearing apparel and other articles used in the penitentiary are to be manufactured there and also such articles as are used by the state, including building materials for state institutions.

Sec. I08-9II. Inmates of the reformatory may be employed in "agriculture, horticulture, or other mechanical labor, as a means of their support and reformation."

District of Columbia. 42 Acts of Congress affecting the District of Columbia 473; Public Act No. 602, 76th Congress, ch. 333, 3d Session. With respect to the workhouse and reformatory of the District of Columbia a working capital fund of $\$ 30,000$ is provided for such industrial enterprises as may be approved. A revolving fund is also created "for the purchase of raw materials and manufacturing supplies . . . and purchase of fuel for manufacturing purposes.

Federal. $\quad 18$ U. S. C. A. sec. 744a ff. "It shall be the duty of the Attorney General to provide employment for all physically fit inmates 


\section{I64 THE PREVENTION OF REPEATED CRIME}

in the United States penal and correctional institutions in such diversified forms as will reduce to a minimum competition with private industry or free labor." The Attorney General "may make available the services of United States prisoners" for road building, reforestation, construction of levees and other public works. Also he "shall establish such industries as will produce articles and commodities for consumption" in various Federal institutions, and in so doing shall provide such forms of employment "as will give the inmates a maximum opportunity to acquire a knowledge and skill in trades and occupations which will provide them with a means of earning a livelihood upon release." Various "working-capital funds" are provided. The President is authorized to create an organization to be known as the "Federal Prison Industries" for the purpose of carrying out these industrial policies.

The notion of rehabilitation through training in trade skills is, of course, not confined to any one country. The Cuban Criminal Code expressly provides, art. 48 , that in all establishments subject to the jurisdiction of the Superior Council of Social Defense there shall be established a system designed to correct and rehabilitate the inmates through individualized treatment and compulsory work and education. The primary purpose, art. 50, of the education and work is to be modification of the diseased and antisocial tendencies, inclinations and predispositions which lead them to crime; the secondary purpose is to assist them in earning a living when returned to freedom.

So, too, the rehabilitation idea is clearly embodied in Swiss criminal law, although it is confused, or at least interwoven, with the punitive processes. The Swiss Federal Criminal Code of 1937, translated by Friedlander and Goldberg, 30 J. Crim. L. I (1939), sets up the customary type of penalties for crime. But it also provides that (Art. 43):

"If the offender has been sentenced to a prison term for a felony or misdemeanor, the court may suspend sentence and commit him to a house of correction for an unlimited period. . . . The committed person shall be trained for the kind of work to which he is suited, and which will enable him to support himself after release. The physical, mental and particularly the industrial development of the committed person shall be furthered by the instruction given." 


\section{Appendix $J$ \\ Educational Rehabilitation}

OTATUTORY provision for general education in the prisons is not so common as is provision for industrial employment. What does appear ranges all the way from the Kansas provision that illiterate convicts shall be instructed in reading, writing and arithmetic, to the Indiana requirement that the board of control shall institute such instruction of an educational nature as they believe will be for the best interests of the prisoners. In no state, however, is educational effort precluded, and in any state the possible effort seems to be limited only by the lack of financial provision.

California. Statutes and Amendments (1941) ch. 937, sec. 1760. The Youth Correction Authority may establish and operate educational institutions for convicts committed to it.

Idaho. I Code Ann. (1932) sec. 19-3904. When a prisoner is received into the penitentiary, he shall be given an examination in fundamental studies taught in the state's common schools and unless he passes it, "he shall be instructed in such studies as may be deemed practicable and advisable; and each and every prisoner shall be given such courses from the university extension department as may be found practicable. . . ."

Sec. 19-3905. The state board of education is to prepare courses of study and the state board of prison commissioners to make necessary arrangements for the education of prisoners.

Sec. 32-2214. Superintendents of state reformatories are to make suitable provision for the teaching of physiology and hygiene.

Indiana. 4 Stats. Ann. (1933) sec. I3-123. The board of each penal institution "shall make the necessary provision for . . . such training in character-building and the moral rehabilitation of the inmates as may be deemed necessary to reclaim the persons who are incarcerated in such institution, so that at the expiration of their 
terms . . . they may be returned to society better fortified to resist the temptations which led to their imprisonment and as useful and self-respecting citizens of the community."

Sec. 13-215. The board of control of the state prison is to "institute such instruction of an educational and technical nature, as, in their judgment, shall be to the best interests of the inmates."

Kansas. Gen. Stats. Ann. (1935) sec. 76-2413. The warden of the penitentiary "shall cause to be instructed in the principles of reading, writing and arithmetic" such convicts as cannot read.

Louisiana. Code of Crim. Proc. (1932) sec. 1472. Inmates of the Louisiana Training Institution shall "receive an educational, moral, industrial and farm training."

Massachusetts. 4 Ann. Laws (1933) ch. I27, sec. 89. The warden of the prison may maintain "schools of instruction for the prisoners at such times, except on Sunday, as he, with the approval of the commissioner, may determine, and for such purpose may expend, from the appropriation made for the support of the prison, not more than $\$ 2,000$ annually."

Sec. 9I. The superintendent of the reformatory may expend annually a sum not exceeding $\$ 5,000$ "for the mental instruction of the inmates."

Michigan. 3 Comp. Laws (1929) sec. I7597. (Mich. Stats. Ann. $\S 28$.I 424.) "A school shall be maintained in each prison for the instruction of convicts confined therein."

Montana. 5 Rev. Codes (1935) sec. 12440.1 ff. Acknowledges a trust fund of $\$ 25,000$ set up by a private donor with which to maintain a prison band, musical instruction, and the equipment therefor, and for the employment of a musical director at $\$ 2,500$ a year.

Nebraska. Comp. Stats. (1929) sec. 83-95 I. The state superintendent of public instruction is authorized to establish and supervise a school for prisoners whereby to give them instruction in common school branches of knowledge, business forms, and useful industries.

Sec. 83-953. It is a duty of the warden to provide a night school, games, and amusements, especially those having an educational value "in order to promote the general moral and physical welfare of the 
prisoners, improve the discipline and provide for their mental development."

New Hampshire. Rev. Laws (1942) ch. 464, sec. 6. It is the duty of the board of trustees "to provide such books and other instruction as shall be deemed necessary for the convicts."

New York. IoB McKinney's Consol. Laws Ann. (1938) sec. I36. "The objective of prison education . . . should be the socialization of the inmates through varied impressional and expressional activities, with emphasis on individual inmate needs. The objective of this program shall be the return of these inmates to society with a more wholesome attitude toward living, with a desire to conduct themselves as good citizens and with the skill and knowledge which will give them reasonable chance to maintain themselves and their dependents through honest labor. To this end each prisoner shall be given a program of education which, on the basis of available data, seems most likely to further the process of socialization and rehabilitation. The time daily devoted to such education shall be such as is required for meeting the above objectives." Provision is made for furnishing of teachers.

North Carolina. Code Ann. (1935) sec. 7732. Authorizes organization of classes among the prisoners so that those who desire may receive instruction in various lines of education. The board is expected to utilize where possible the services of prisoners who are sufficiently educated to act as instructors for such classes.

Ohio. Throckmorton's Code Ann. (1940) sec. 2 195. 'The board of administration may establish, at the penitentiary, an elementary day school for uneducated prisoners, and to that end may employ a competent and efficient superintendent of school and such number of assistants and teachers as may be necessary. It may provide school rooms and books, stationery and apparatus.

Sec. 2195-2. The board may establish and maintain manual training, domestic science, and commercial departments. The nature of alcoholic drinks and other narcotics, and their effects upon the human system may be included in the branches to be taught.

Oregon. 8 Comp. Laws Ann. (1940) sec. 127-105. There shall be appointed two clergymen for the penitentiary and training 
school, one Catholic and one non-Catholic. They shall give the inmates moral and religious training, "visit the sick in the hospital and devote six hours each week to instructing the convicts and the boys in the training school in the common branches of knowledge." Their salary shall be $\$ 600$ each annually.

Pennsylvania. Purdon's Stats. Ann. (1930) tit. 6r, sec. 346. The board of trustees shall elect a chaplain for a term of four years. They shall procure suitable religious instructors, in addition to the chaplain.

Sec. 378 . It shall be the duty of the religious instructor to "attend to the moral and religious instruction of the convicts, in such manner as to make their confinement as far as possible the means of their reformation, so that when restored to their liberty, they may prove honest, industrious and useful members of society."

Sec. 380 . Prisoners at the western penitentiary may be congregated for the purposes of " . . . learning and religious services."

Sec. $38 \mathrm{r}$. Prisoners at the eastern penitentiary may be congregated for the purposes of "worship, labor, learning, and recreation: Provided, That no person shall be brought into an assembly for common worship unless such person so desires."

Sec. $3^{8} 3$. Prisoner may subscribe to any "daily, weekly or monthly paper or periodical of a moral, political or religious character," if he has the means to pay for the same; and provided that such papers and periodicals first meet the approval of the board of trustees of such penitentiaries.

Rhode Island. Gen. Laws (1938) ch. 50, sec. 6. The director of the department of public welfare shall appoint religious instructors for the institutions, such instructors to be paid by appropriations from the assembly.

Sec. I I. The director of the department of public welfare shall annually make a report to the department of education on all schools maintained in the institutions under his care. The director of education may visit these schools and make suggestions as to their improvement. "All teachers employed in said schools, except the schools maintained at the state prison, shall hold certificates of qualification as required by law of public school teachers." 
Tennessee. Michie's Code Ann. (1938) sec. 12103. All prisoners under twenty-one shall be kept apart from older and hardened criminals except those of good conduct and example. They shall be under the charge of the chaplain and the warden. "The chaplain shall be permitted, after the working hours, to furnish, and shall furnish, instruction in education and moral training to such convicts, under twenty-one years old as shall desire to take advantage of the same, not more than two hours a day, and a suitable place within the prison walls shall be furnished for such school."

Sec. 12 104. The chaplain shall instruct "little boys, both white and black, of sixteen years and under" morally and educationally for at least two hours a week.

(Apparently the "little boys" are incorrigibles or those sentenced for murder or rape.)

Sec. I 2 I26. Every convict shall be furnished with a Bible.

Secs. 12128 and $12129 . \$ 250$ shall be appropriated annually for maintaining a library at the state prison. The state librarian shall control said branch library.

Texas. I7 Vernon's Civil Stats. (1925) art. 6203b. The prison board shall arrange for the teaching of reading, writing, spelling and arithmetic to all inmates of the prison. Illiterates shall receive five hours' instruction per week. Literate prisoners may organize "for themselves special instruction or classified instruction of a higher class. . . ." Such instruction shall be under the direction of the prison chaplains. "There shall be read and explained for at least one hour of each school week portions of the Constitutions of the United States and the State of Texas."

Utah. 5 Code Ann. ( 1943) sec. 85-9-50. The board of correction may charge not over $\$ .25$ of each visitor for the visit and it shall appropriate annually out of receipts "such sum as it may determine for the purchase of books to be kept at the prison for the use of convicts."

Sec. 85-9-5 I. "A school may be maintained in the prison for the instruction of convicts confined therein. It shall be conducted under such regulations as may be made by the board of corrections."

Sec. 85-9-52. Prison library to be maintained. 


\section{THE PREVENTION OF REPEATED CRIME}

Vermont. Pub. Laws (1 933) sec. 8805. "Persons committed to the house of correction who are under twenty years of age shall be instructed at reasonable times in the branches required to be taught in the public schools; and prisoners above that age shall receive such facilities for reading and such instruction as, in the discretion of the superintendent, is reasonable and consistent with the discipline of the institution."

Sec. 881 I. State board of education shall provide suitable libraries in the penal institutions.

Sec. 88I4. Prisoners "shall have access to books and newspapers under such regulations as the warden or matron with the approval of the governor may prescribe."

Sec. 8806. Chaplains shall hold religious services on Sunday, "and attend to and instruct the prisoners in their moral and religious duties and visit the sick on suitable occasions."

Virginia. Code (1942) sec. 5048i. The board of directors of the penitentiary is authorized to arrange for lectures, etc., for prisoners' leisure, organize classes for those who desire instruction and utilize "the services of the prisoners who are sufficiently educated to act as instructors for such classes in education; such services, however, shall be voluntary on the part of the prisoner."

Washington. Io Remington's Rev. Stats. Ann. (1932) sec. 102.23-2. Director of business control shall have power to make rules as to education.

Sec. 10235 . It is the duty of the chaplain to give religious and moral instruction, and to devote at least one hour each weekday and Sunday afternoon to such instruction; to take charge of library; to make a quarterly report to the governor stating the number of convicts instructed during the last quarter, branches of education in which instructed, text-books used, progress made by convicts, and especially cases of unusual progress.

Wisconsin. Stats. (I94 I) sec. 53.06. The chaplain shall hold religious services each Sunday, "instruct the prisoners in their moral and religious duties and visit the sick on suitable occasions. He shall also act as librarian." Once a week he shall devote three hours "to instructing those prisoners who need such instruction in the common 
branches of English education." He may use qualified convicts to assist him in his teachings.

District of Columbia. 42 Acts of Congress affecting the District of Columbia 473; Public Act No. 602, 76th Congress, ch. 333, 3d Session. Appropriation for the purchase of newspapers, books, and periodicals for the jail not to exceed $\$ 100$; appropriation for the purchase of newspapers, books, books of reference, and periodicals for the workhouse and reformatory not to exceed $\$ 1500$; also provision for purchase of books, magazines, and other educational supplies for the National Training School for Girls.

Federal. $\quad$ i 8 U.S.C.A. secs. 817,837 . There appears to be no specific provision for education in the Federal prisons generally, but these sections provide that in the Federal industrial institution for women and the United States industrial reformatory, it is the duty of the Attorney General to provide "instruction in the common branches of an English education," as well as in "such trade, industry, or skilled vocation" as will enable the prisoners to become self-supporting after release. 


\section{Appendix K}

\section{Medical and Surgical Treatment}

\section{$\complement^{\mathrm{EG}}$}

EGISLATURES appear to have had no appreciation of the fact that tendencies toward repetitious criminality can often be weakened and even eliminated by medical or surgical treatment. Nowhere in the statutes is there explicit provision for investigation of specific physiological causes of crime and their treatment by physicians or surgeons. But, on the other hand, there is recognition of the part which abnormal mental conditions may play in criminal activity, and some state statutes do provide at least for study of such conditions. Such are the New York provision that the commissioner of correction shall establish a psychiatric clinic for the study of each convict received at Sing Sing, and the statutes of Illinois and Michigan requiring psychiatric examination. Moreover, many statutes are general enough to permit unlimited progress along the lines of crime prevention through correction of physical and mental defects, and perhaps were based on real intention to open the way for such practices. Indiana authorities, for example, are authorized "to adopt such rules concerning all prisoners committed to their custody as shall prevent them from returning to criminal courses." This might be interpreted as authorizing "rules" of corrective physical betterment. Certainly, Kentucky correction officials would seem specifically authorized to utilize medicine and surgery in their statutory obligation "to study the sources and causes of crime . . . and to put into effect such remedial measures as may be of benefit . . ." In many other states it is obvious that the legislative idea was no more than humanitarian consideration for the day to day health of prisoners, as in the Massachusetts provision that a physician shall visit the 
prison hospital once a day and prescribe for sick convicts. But even in these states there appears to be no statutory preclusion from the reasonable use of medicine and surgery as crime preventives if there is the will to use them and the financial means to do so.

Again the failure of prison administrators to put such remedial and preventive practices into effect must be attributed to something other than a lack of at least implicit authority in the statutes.

Alabama. Code (1940) tit. 22, sec. 265. Prisoners are to be examined for venereal disease; if found to be infected, they are to be confined separately from others and to be given proper treatment.

Tit. 45, sec. 4I. Prisoners suffering from tuberculosis are to be separated from others.

Arkansas. Digest of Stats. (1937) sec. 12704. Requires services of a full-time physician for all necessary medical services, to prescribe diet for sick, keep records of sick, etc.

California. Penal Code (I94I) sec. 2670. Whenever in the opinion of specified officials it will be of benefit to the physical, mental or moral condition of a recidivist who has been twice confined for sex offenses and shows criminal sexual tendencies, he may be asexualized.

Colorado. 3 Stats. Ann. (1935) ch. 78, sec. 54. Prisoners confined in any common jail who have a disease which is dangerous to the safety and health of others may be removed to a hospital.

Ch. 78, sec. 168. All persons confined or imprisoned "shall be examined for, and, if infected, treated for venereal diseases by the health authorities having jurisdiction. . . ."

Connecticut. Gen. Stats. (1930) sec. 1978. The warden of the state prison "shall provide for the relief of any sick or infirm prisoner, and the cost thereof shall be paid by the state from funds appropriated and available for such purpose. . . ."

Sec. 2374. Any person confined in the state prison or jail for ten days or longer "may be examined for any malignant, infectious or contagious disease, and if found infected with any such disease, he shall be treated during the term of his confinement and, if not cured 


\section{THE PREVENTION OF REPEATED CRIME}

at the date of his discharge, the local health officer shall be notified. . ."

Florida. Stats. (I941) sec. 954.43. "The board of commissioners of state institutions may employ one or more state prison physicians. . ."

Sec. 954.44. "The physician shall visit the hospital of the prison at least once in each day, and as often as is necessary, prescribe for the convicts who are sick. . . ."

Sec. 384.08. All persons imprisoned in any state, county, or city prison may be examined and treated for venereal diseases.

Georgia. Code Ann. (I933) sec. 77-306. The prison commission "shall appoint such officers and physicians as may be necessary. . . "

Sec. 88-504. Prisoners may be examined and treated for venereal disease by the health authorities.

Idaho. I Code Ann. (1932) sec. 20-314. "It shall be the duty of the physician to attend at all times to the wants of sick convicts, and to prescribe medicine and diet for them." He shall determine whether a convict is unable to work because of illness and shall examine the cells, the sanitary arrangements, and the food and clothing of the convicts once a week.

Illinois. Rev. Stats. (1935) ch. 108, sec. I09. (Jones Ann. Stats. 99.092.) Prisoners are to be first delivered to "diagnostic depots" for preliminary study. "Such survey shall include a consideration of his previous criminal record, if any, and a physical, psychological and psychiatric examination."

Indiana. 4 Stats. Ann. (1 933) sec. 13-4I I. The board of managers of the reformatory are to "adopt such rules concerning all prisoners committed to their custody, as shall prevent them from returning to criminal courses. . . . "The superintendent is to keep a record of facts concerning the prisoners, including such "early social influences as seem to indicate the constitutional and acquired defects and tendencies of the prisoner, and, based upon these, an estimate of the present condition of the prisoner and the best probable plan of treatment. . . ." 
Iowa. Code (1939) sec. 3329. The board of control is to "encourage the scientific investigation, on the part of the executive heads and medical staff of the various institutions, as to the most successful methods . . . of treating the persons committed thereto. . . ."

Kansas. Gen. Stats. Ann. (1935) sec. 76-2401. Among the officers of the penitentiary shall be one physician and surgeon.

Kentucky. Carroll's Stats. (1930) sec. 216a-3. Board of charities and corrections is under a duty "To study the sources and causes of crime, delinquency, and dependency and as far as possible suggest and put into effect such remedial measures as may be of benefit to the Commonwealth in the prevention and ultimate eradication of antisocial acts and conditions. . . ."

Louisiana. Code of Crim. Proc. (1932) art. 1432. The board of control is to "make rules for the grading and classifying of the convicts according to the most modern and enlightened system of reformation . . . the purpose being to restore and reform the individual to a better man, physically, intellectually and morally."

Maine. Rev. Stats. (1930) ch. 152, sec. 40. "The commission and warden shall appoint some suitable person physician and surgeon of the prison, who shall visit the same daily, . . . attend and prescribe for sick convicts. . . ."

Ch. I52, sec. 4I. Provides for removal and medical care of all convicts with a contagious disease.

Ch. 94, sec. 40. ". . . whenever a convict at the expiration of his sentence, is sick and unable to be removed from jail, he shall be cared for by the jailer, at the expense of the county, until the county commissioners deem it safe for him to be removed."

Ch. 22, sec. 134. Provides for reporting of venereal diseases in correctional institutions and compliance with such rules and regulations as the state health department may impose to prevent the spread.

Massachusetts. 4 Ann. Laws (1933) ch. 125, sec. I7. A physician shall visit the prison hospital once a day and prescribe for sick convicts. He shall also keep a record of admission to the hospital and treatment.

Ch. 127 , sec. 16. Heads of penal and reformatory institutions shall cause a thorough physical examination to be made of prisoners ad- 


\section{I76 THE PREVENTION OF REPEATED CRIME}

mitted, especially for evidence of gonorrhea, syphilis, and pulmonary tuberculosis.

Michigan. 3 Comp. Laws (1929) secs. 17573, 17543-45. (Mich. Stats. Ann. $\$ \S 28.1400,28.2$ I05.) These provide for records to be kept concerning the social attitude of prisoners, the type of work which they have done in prison, and an estimate of the extent to which they have responded to these influences; together with the result of whatever physical, mental, and psychiatric examinations may have been made. By implication, this would seem to authorize at least the making of physical, mental, and psychiatric examinations and application of constructive efforts to the needs of the individual.

Minnesota. 2 Mason's Stats. (1927) sec. ro805. In case of epidemic in the state prison, prisoners may be removed to some other secure and suitable place for care and treatment.

Mississippi. I Code Ann. (1930) sec. I 9 I I. A full-time physician and a full-time dentist are to be employed.

Sec. I95I. The prison hospital is to be under control of the prison physician, who can hire not more than four nurses and shall provide free care and treatment to convicts and employees of the penitentiary.

Missouri. 2 Rev. Stats. (1939) sec. 9036. A physician is to be appointed for the penitentiary at not more than $\$ 4,000$ per year salary, who is to devote his entire time to the health and treatment of prisoners requiring medical attention.

Montana. 2 Rev. Codes Ann. (1935) sec. 2569. All persons imprisoned in state, county, or city prisons shall be examined and treated for venereal disease.

Nebraska. Comp. Stats. ( I 929) sec. 83-901. Provides for employment of a physician for the penitentiary.

Sec. 29-2622. The penitentiary physician and warden are to examine prisoners and keep a record of observed improvement or deterioration of character and notes as to the method and treatment employed, and to make an estimate of the condition of the prisoners and the best plan for their treatment.

Nevada. 5 Comp. Laws (1929) secs. I 1479-1 1484 . Provide for dental service for the inmates of state institutions. 
New Jersey. I Rev. Stats. (1937) sec. 30:4-7. Boards of managers are authorized to place prison inmates in any hospital in the state "for such medical or surgical treatment as may be necessary, which cannot properly and adequately be rendered within the institution, and to pay for the care, maintenance and treatment of such persons."

New York. IoB McKinney's Consol. Laws Ann. (1938) secs. 148, 149. The commissioner of correction is directed to organize and establish a psychiatric and diagnostic clinic at Sing Sing prison. Its work shall include scientific study of each criminal, his career and life history, investigation of the cause of his crime, and recommendations for the care, training, and employment of criminals, with a view to their reformation and to the protection of society.

North Carolina. Code Ann. (1935) sec. 7207 ff. Examinations of prisoners are to be made for the discovery of tuberculosis, and special provision for their cure.

Sec. 7221 . The medical staff of any penal or charitable institution is permitted and instructed "to have any surgical operation performed by competent and skillful surgeons upon any inmate . . . when such operation would be for the improvement of the mental, moral, or physical condition of such inmate." A commission consisting of at least one representative of the medical staff of the institution and one member of the board of health is created for the execution of this provision.

Sec. 7 I 94 . Provides for the treatment of venereal disease of prisoners.

Sec. 7216 . Provides for a thorough physical examination of prisoners within 48 hours after their admission.

North Dakota. Comp. Laws (1913) sec. I126I. "The state board of control shall establish rules and regulations relating to care, treatment, and management of all prisoners. . . ."

Sec. I 1265. ". . . Any prisoner who requires medical, surgical or dental treatment, not provided by the state may use the money to his credit in any fund to defray the expenses of such treatment. . . ."

Ohio. Throckmorton's Code Ann. (r940) sec. 2180. Provides for a physician for the penitentiary. Sec. 2194. The physician is to keep "a correct record of vital statistics of the penitentiary . . . 


\section{I7 8 THE PREVENTION OF REPEATED CRIME}

a statement of the condition of the heart, lungs, . . . and any existing disease, deformity, or other disability acquired or inherited. $\mathrm{He}$ shall perform such other duties in the line of his profession as the board of managers requires."

Oklahoma. Stats. (I94I) tit. 57, sec. I34. The warden has power to appoint a physician at a salary of $\$ 3000$ a year.

Tit. 57 , sec. 163 . Provides a fund to pay for surgical treatment of prisoners.

Tit. 63 , sec. 24. A prisoner with a disease dangerous to the safety and health of the other prisoners or inhabitants of the town may be removed to a hospital.

Oregon. 6 Comp. Laws Ann. (1940) sec. 91-215. The board of control is authorized to employ necessary physicians and nurses.

In cases of necessary or emergency operations requiring a specialist the board is authorized to have such operations performed even if relatives are unable to pay for it.

Pennsylvania. Purdon's Stats. Ann. (1930), tit. 6I, sec. r. Any person sentenced and admitted to any jail, prison, or penitentiary in the state is to be examined as to his mental condition, within fortyeight hours of his admission. A record of such examination is kept as a part of the records of the institution.

Sec. 3. "All prisoners who are found to be mentally weak shall be segregated from the other prisoners and not allowed to be among or mingle with those whose mentality is found to be normal."

Sec. 372. "The physician shall visit every prisoner in the prison twice in every week," and oftener if necessary. He shall examine every prisoner on admission. If any convict is ill he shall be removed to the infirmary. The physician shall visit the patients in the infirmary at least every day. "The physician shall inquire into the mental as well as the bodily state of every prisoner, and when he shall have reason to believe that the mind or body is materially affected by the discipline, treatment, or diet, he shall inform the warden thereof, and shall enter his observation on the journal hereinafter directed to be kept, which shall be an authority for the warden for altering the discipline, treatment or diet of any prisoner, until the next meeting of the Board of Trustees, who shall inquire into the case and make orders accord- 
ingly." The physician shall keep a journal of all the prisoners and the state of their health.

Rhode Island. Gen. Laws (1938) ch. 54, sec. I. The department of public welfare "shall furnish all necessary medical aid and attention, and shall take all necessary steps to promote the health of inmates, prisoners, patients and pupils, and especially to guard them and the general public against all dangerous, infectious and contagious diseases. . . "

Ch. 50, sec. 5. The director of the department of public welfare shall appoint resident physicians and dentists for the institutions under his department.

South Carolina. 2 Code of Laws (1942) sec. 3847 . "The county board of commissioners shall be authorized and required to employ a physician or physicians whenever necessary to render medical aid to sick convicts and to preserve the health of the chaingang. . . ." The county shall not be liable for any surgical or dental fees or any hospital bills unless the board of county directors authorizes the treatment.

3 Code of Laws ( I 942) sec. 5020. It is the duty of the board of health to inspect the prisons and jails for sanitary facilities, etc.

Sec. 5044-3. Examination and treatment of prisoners for venereal disease authorized.

South Dakota. Code (1939) sec. 13.47 16. Relates to solitary confinement and mentions that such prisoners should be fed on bread and water "unless a physician called upon to ascertain the fact shall certify to the Warden that the health of the convict requires other diet."

Tennessee. Michie's Code Ann. (1938) sec. I210r. Physician "shall from the fifteenth day of November to the fifteenth day of March visit the prison each day at the hour of 7 o'clock a.m. and examine the physical condition of the convicts and pass upon their ability to work. If unable to work, he shall direct that they be returned to their cells or to the hospital. From the fifteenth day of March to the fifteenth of November he shall visit the prison at the hour of 6:30 o'clock a.m. each day, for the purpose mentioned above." 
Texas. I7 Vernon's Civil Stats. (1925) art. 6166z9, sec. 3. All employees of the prison shall have free medical advice from the prison physician and free hospitalization in the prison hospital when injured in discharge of duty.

Art. $6203 \mathrm{C}$, sec. $2 \mathrm{~B}$. The board shall provide adequate hospitalization "including equipment for the scientific diagnosis and treatment of diseases. . . ."

Sec. 2D. Each prison farm shall be equipped with a hospital ward.

Utah. 5 Code Ann. (1943) sec. 85-9-19. Prison physician to give all "necessary medical attention," inspect cells, keep records of sick, etc.

Virginia. Code (1942) sec. 5022. "The surgeon shall render to the convicts all surgical and medical aid which may be requisite." $\mathrm{He}$ must visit the penitentiary every day and oftener if necessary.

Sec. 5023. A room shall be set aside for a hospital room.

Sec. 5012. The hospital room shall be whitewashed twice a year and the floors washed as often as necessary for "health and comfort."

Sec. 5047. There shall also be a surgeon for the penitentiary farm appointed by the board, who shall be paid $\$ 50$ per month and "board for himself and horse."

Sec. 5058 (I). There shall be a special state prison farm for "defective misdemeanants" including "the tubercular, the venereal, the drug addicts, the inebriates, the psychopathic personalities," etc.

Sec. 5058 (14). "It shall be the general purpose of the said State prison farm for defective misdemeanants, and other farm or farms, to provide proper employment, medical and mental care and treatment . . . of prisoners committed. . . . "Any prisoner infected with a contagious disease shall not be discharged until the period of contagion has passed, regardless of the length of sentence, provided it shall not be for more than a year over the original sentence, unless by an order of the health department.

Wisconsin. Stats. (1941) sec. 46.12. Board of control appoints "from time to time" a surgeon and an alienist to examine the mental and physical condition of inmates of institutions under the board's control.

Sec. 46.115. Convicts needing medical or surgical treatment are sent to Wisconsin general hospital, if they cannot receive proper care at the institution to which they have been committed. 
Sec. 54.0I. The reformatory for women is to maintain ". . . a psychological laboratory for the study and treatment of mental disorders to which women and girls addicted to immoral practices are subject. . . ."

Wyoming. Rev. Stats. (1931) sec. 103-236. Provides for examination for and treatment of venereal diseases.

District of Columbia. 42 Acts of Congress affecting the District of Columbia 473; Public Act No. 602, 76th Congress, ch. 333, 3d Session. Authorization to purchase medical supplies for workhouse and reformatory. Appropriation for medical and dental care for $\mathrm{Na}-$ tional Training School for Girls. Provision for compensation of consulting physicians for District Training School.

Federal. 18 U.S.C.A. sec. 751. The Federal Security Agency is required to detail officers of the Public Health Service, pharamacists, surgeons, etc., "for the purpose of supervising and furnishing medical, psychiatric, and other technical and scientific services to the Federal penal and correctional institutions." 


\section{APPENDIX L}

\section{Assistance to Persons Released on Parole}

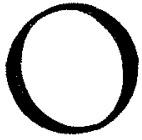

$\mathrm{NE}$ of the primary purposes of parole is supervision of the parolee for a time after his release from prison. This supervision could be merely a watchful eye, to see that he keeps out of bad company and otherwise behaves as he should. It might also be for the purpose of actively assisting him to find substitutes for bad company and, particularly, to find the means of livelihood without resort to crime. It may be accepted that the theory of parole and the wishes of parole officers put even more emphasis on the latter objective than the former. But active assistance requires a larger personnel and markedly greater financial provision than does mere watchful supervision. While statutes make some slight, usually very slight, provision for the immediate support of persons released on parole-say $\$ 5, \$ 1 \mathrm{IO}$, or even $\$ 25$ - and sometimes give utterance to the idea of "assisting" them, they do not in fact make provision, as a practical matter, for anything more than watchful supervision and mere advice. Some of the statutes do require that parolees must have a job waiting for them before they can be released, and any state parole board can so require. So also some statutes require parole authorities to be active in finding jobs for prospective parolees and in other states the authorities make that a practice. The trouble, therefore, and the obvious insufficiency in the legislation, is in the matter of new employment after the first job has terminated, and in the problem of support during an idle period. The Iowa statute carefully limits monetary aid during such a period of stress to a loan of $\$ 25$; that of Rhode Island provides not to exceed $\$ 5$ per week for certain female 
parolees. Tennessee requires parolees to pay for their own supervision.

Arizona. 3 Code Ann. (1939) sec. 47-I I 8. "The parole clerk (apparently of the board of pardons and paroles) shall aid in securing proper employment for all paroled prisoners, and also for those who have been discharged before the maximum time for which they were sentenced.

Sec. 47-120. Every prisoner when he leaves prison shall be furnished with $\$ 5$ in cash and a suit of clothes not exceeding in cost $\$ 15$, and an untransferable ticket on any railway adjacent to place of discharge for any continuous distance not to exceed 300 miles in any direction.

Sec. 44-3007. Chairman of the board of pardons and paroles shall be $e x$ officio the supervisor of parolees and shall "contact parolees and give field supervision whenever possible."

California. Penal Code (I94I) sec. 3057. "State Board of Prison Directors shall have the power and authority to provide for assisting paroled prisoners and to secure employment for the same and for that purpose they may employ necessary officers and employees, may purchase tools, and give any other assistance that, in its judgment, they may deem proper for the purpose of carrying out the objects and spirit of this section."

Sec. 1203.I. Court may require probationer to work on public works in county same as prisoners in county jail, and supervisors of counties are authorized to provide public work for them and fix scale of compensation for them.

Colorado. 4 Stats. Ann. (1935) ch. I31, sec. 87. "Ten days prior to the day on which any convict now confined, or that may hereafter be confined in the penitentiary of this state, shall be entitled to be discharged or to be paroled from said penitentiary, the warden . . . shall give such convict a ticket of leave. . . . The warden shall at the same time furnish such convict with five dollars, a suit of clothes as now provided by law in case of the discharge of a convict from the penitentiary, and a non-transferable railroad ticket, at the expense of the State, . . ." 


\section{THE PREVENTION OF REPEATED CRIME}

Delaware. Rev. Code (1935) 4157. It is the duty of parole officers "to aid prisoners released on parole to secure employment, to visit and exercise supervision over them while on parole, to see that they fulfill the conditions of their release and to perform such other duties as the Board of Parole may determine."

Florida. Stats. (I941) sec. 947.17. A person released on parole "shall be given his transportation by the nearest route to the destination noted in the parole. In addition thereto he shall be given a suit of clothes, one pair of shoes, a hat, a suit of underclothing, not to exceed in value, in the aggregate, the sum of fifteen dollars, and ten dollars in cash. . . ."

Georgia. Code Ann. (1933) sec. 775 I3. Makes it duty of prison and parole commission, to provide "adequate supervision for all parolees and probationers in this State, also all persons released on conditional pardon and placed by the Governor under the supervision of the said Commission."

Sec. 77-515. Commission "authorized and empowered to employ such employees necessary to the adequate supervising of parolees and probationers and the conduct of its office" as commissioner may deem necessary.

Sec. 77-517. Commission shall keep within appropriations for it.

Idaho. I Code Ann. (1932) sec. 20-42 I. When any convict is discharged from the prison or released on parole the warden shall furnish him with a decent suit of clothing (if he is not already provided for) at the expense of the state, and shall pay such convict, from any funds belonging to the penitentiary, a sum not exceeding fifteen dollars and shall deliver to said convict any property received from him which has not been disposed of according to law.

Sec. 19-3909. "No prisoner shall be released on parole until the said board of pardons shall have made arrangements or shall have satisfactory evidence that arrangements have been made for his honorable and useful employment while upon parole in some suitable occupation, and at a proper or suitable place free from criminal influence." But prisoners mentally, morally, or physically deficient, or whose interests and that of the state would be best subserved by 
parole without employment, may be paroled without complying with above, but even then board is to make arrangements, or see they are made, for their "keep."

Illinois, Rev. Stats. (1935) ch. 38, sec. 80g. (Jones Ann. Stats. 37.767.) "Upon granting parole to any prisoner or ward the Division of Correction shall provide him or her with suitable clothing, $\$ 10$ in money which may be paid to him or her in installments at the discretion of the Division and shall procure transportation for him or her to his or her place of employment."

Indiana. 4 Stats. Ann. (1933) sec. ${ }_{13}-258$. "It shall be the duty of the warden of the prison to furnish all paroled prisoners the clothing and transportation provided for in section I ( $\$ 13-257)$ of this act and $\$ 5.00$ in money: Provided, however, That when any such paroled prisoner receives his final discharge while he is away from such Indiana State Prison, the provisions of this act shall not apply to such prisoner at the time of final discharge."

Sec. 13-254. "The warden of each prison shall appoint an agent whose duty it shall be to aid and secure proper employment for all prisoners who have so conducted themselves as to be entitled to go out from such prison on parole, and also for those who have become entitled to an absolute discharge before the maximum time for which they were sentenced, and to keep the said warden informed of the conduct of said prisoners when out upon parole, and to make a report as to each prisoner in such matters on the first day of each month for the preceding month."

Sec. I3-413. "It shall be the duty of the general superintendent (of reformatory) to appoint an agent to aid, and secure, if possible, proper employment for all prisoners who have so conducted themselves as to be entitled to go out from said reformatory upon a parole, and also for those who have become entitled to an absolute discharge before the maximum time for which he was sentenced."

lowa. Code (1939) sec. 3789. "No person shall be released on parole until the board of parole shall have satisfactory evidence that arrangements have been made for his employment or maintenance for at least six months. Said board may render assistance to prisoners 
about to be paroled in procuring employment and the necessary expense incident thereto shall be paid as other expenses of the board are paid."

Sec. $3797 \mathrm{ff}$. Sets up parole relief fund of \$1250, and next section provides that it may "be used for the relief of paroled prisoners who are in distress because of illness, loss of employment, or conditions creating personal need," but not to exceed $\$ 25$ to any prisoner, and latter must give note to repay during period of parole.

Sec. 3736 . Duty of superintendent of women's reformatory "so far as practicable, to obtain for each inmate before she is paroled or discharged a home and suitable employment if they are not otherwise provided."

Sec. 3737. Superintendent of women's reformatory may, "with the consent of the board of control, furnish a discharged or paroled inmate with proper clothing, and a receptacle therefor, and transportation to her place of employment, or home, or other place not more distant than the place of commitment, and a sum of money not exceeding $\$ 25$."

Sec. 3796. "When a prisoner is paroled, he shall be furnished, by the warden, with such clothing, transportation, and money as is provided for prisoners when discharged at the termination of their sentence, but no further allowance shall be made if final discharge is granted while on parole."

Kansas. Gen. Stats. Ann. (1935) sec. 62-22 11. When court places person before it on parole (probation?) he shall appoint a person or society as patron for said prisoner, who shall "use his best efforts to furnish, for said paroled prisoner, regular and continuous employment, or to secure such employment from others, or to approve and supervise any efforts of said paroled person to engage in any business or occupation for himself. . . ."

Kentucky. Acts (1936) ch. 30, sec. 5. Department of public welfare to appoint a director of probation and parole for the state, and he to appoint necessary probation and parole officers "as are required for service in the Circuit Courts, and for the supervision of persons paroled from the institutions under the control of the Department of Public Welfare." Director to receive not more than $\$ 3000$ a year and parole officers not more than $\$ 1800$. 
Sec. 7. Probation or parole officer shall keep informed as to "conduct and condition" of each person under his supervision and "shall use all practicable and suitable methods, not inconsistent with the condition imposed by the court, or Department of Public Welfare, to aid and encourage persons on probation or parole and to bring about improvement in their conduct and condition."

Carroll's Stats. (1930) iec. 3828-2. Before paroling prisoner, board of charities and corrections shall "ascertain whether the applicant has secured, or had secured for him or her, some respectable employment with a solvent, reputable person, firm or corporation at a compensation sufficient to render such applicant self-sustaining after parole, which employment shall be evidenced by a written contract of employment for at least six months," but no stipulated wages necessary in contract for those under sixteen where home for such procured or they are apprenticed under written contract for support, etc., nor is contract necessary where prisoner has sufficient estate giving him self-sustaining income. Governor must also approve parole.

Sec. 3828-8. Two full-time employment agents to be employed by state board of charities and corrections at $\$ 100$ a month and traveling expenses, whose duty it shall be "to solicit, procure and make contracts, subject to the approval of said board, for the suitable employment, in advance of their parole, of such persons as may be paroled by said board; to assist them in keeping so employed at all times while so on parole; inspect and report to said board in such manner and at such time as it may by rule provide, concerning the employment, habit and surrounding of such paroled prisoners; and where such surroundings or employment are not beneficial to any person on parole, to recommend and endeavor to procure different employment; to counsel, aid and encourage such paroled prisoners and assist them to become self-sustaining and useful members of society; to investigate and report on breaches of parole, and to perform such other duties and make such other reports as may from time to time be required by said board." Agents to keep familiar with kinds of work that can be performed by those eligible to parole. Board can also designate regular employees of institutions to help in such work.

Louisiana. Code of Crim. Proc. (1932) art. 733. "Every paroled prisoner upon his being discharged upon parole shall be fur- 
nished a suitable suit of clothes, and transportation to such place as he may elect to go within the state of Louisiana, and \$5 in money."

Maine. Rev. Stats. (1930) ch. 147, sec. 40. "Whenever any prisoner is released upon parole he shall receive from the state, clothing not exceeding twenty dollars in cost, and a non-transferable ticket at his own expense. . . . The warden may . . . advance . . the cost of a ticket . . . and expenses not to exceed two dollars, . . failure . . . to return the money . . . within 60 days may be declared a violation of parole. . . ."

Maryland. Ann. Code (1939) art. 4I, sec. 78. Board of parole and probation shall appoint a supervisor of parole and probation who shall be responsible to director of parole and probation. He shall, "with approval of the Board of Parole and Probation formulate methods of investigation and supervision, and develop various processes in the technique of the casework of the official staff of the Division, including interviewing, consultation of records, analysis of the information, diagnosis, plan of treatment, correlation of effort by individuals and agencies, and methods of influencing human behavior. . . ."

Massachusetts., 4 Ann. Laws (1933) ch. I27, sec. 158. Male parole agents who are employed to aid paroled male prisoners shall endeavor to secure employment for them, to provide them with needed assistance, and to perform such other duties relative to paroled prisoners as the commissioner of corrections requires.

Sec. I59. Women agents are to counsel and advise female prisoners who have been paroled, assist them in obtaining employment, and under the direction of the commissioner, render them pecuniary aid.

Sec. $160 \mathrm{ff}$. The commissioner may expend such sum as is annually appropriated for the assistance of prisoners released from the state prison or other institutions. Money may be spent in furnishing clothing, board, and tools. Paroled prisoners may be given up to $\$$ ro in money. Sec. 164 authorizes certain officials to provide prisoners released from county prisons with such an amount of money as in their opinion can be wisely used to encourage their reformation.

Michigan. 3 Comp. Laws ( 1929) sec. 17543-47. (Mich. Stats. Ann. $\S 28.2107$.$) When a prisoner is released upon parole he is to$ 
receive clothing and a non-transferable ticket to the place in which he is to reside. He may be advanced the expenses of such transportation and such further sums not to exceed $\$ 20.00$ as the assistant director of paroles may direct for his temporary maintenance. Failure of the paroled prisoner to return money thus received within sixty days may be declared a violation of his parole.

Sec. 17543-43. (Mich. Stats. Ann. \$ 28.2 1 03.) No prisoner may be released on parole unless provision has first been made for his employment or care.

Minnesota. 3 Mason's Stats. (1927) sec. 10775. The board of parole shall "exercise supervision over paroled and discharged convicts" and may assist them in obtaining employment.

Missouri. 2 Rev. Stats. (1939) sec. 9049. When a prisoner is paroled, pardoned, or otherwise released, from the penitentiary, his earnings during incarceration, if any, up to the sum of $\$ 25.00$ shall be paid to him.

Nebraska. Comp. Stats. (1929) sec. 83-929. When a convict is discharged or paroled, the warden shall at the expense of the state furnish such convict with a decent suit of clothes and an overcoat if he is discharged between the first of November and the first of April, unless he already has an overcoat, and shall give him $\$ 10.00$. He shall also furnish a Bible to each convict who can read.

New Jersey. I Rev. Stats. (I937) sec. 30:4-I I4. The state board has power to prescribe the sum of money not to exceed $\$ 25.00$ which shall be given to a convict upon parole or discharge, and the clothing which shall be provided for him.

Sec. 30:4-123. Institutions may use their petty cash fund for payment of traveling expenses of paroled inmates to their places of employment.

New Mexico. Stats. Ann. (194I) sec. 42-1708. Paroled prisoners are to be provided with suitable clothing, $\$ 5.00$ in money, and transportation to the place of employment if within the state.

New York. IoB McKinney's Consol. Laws Ann. (1938) sec. 125. The warden shall give to each prisoner released by discharge or parole necessary clothing not exceeding $\$ 25.00$ in cost, $\$ 10.00$ in money, and a railroad ticket to such place as the commissioner may 


\section{0}

THE PREVENTION OF REPEATED CRIME

designate. (Amended, Laws (I937) ch. 897 to permit clothing in the winter months of a value of $\$ 40.00$ and $\$ 20.00$ in money.)

I 8 Ibid. sec. I 8 . There shall be in the division of parole an employment bureau whose duty primarily shall be to aid persons coming under the supervision of the board of parole to secure employment, and to perform such other duties as may be prescribed by the board.

IoB Ibid. sec. I3. It shall be the duty of parole officers to aid paroled prisoners in securing employment and to visit and exercise supervision over them while on parole.

North Carolina. Code Ann. (1935) sec. 7757 (20). Paroled prisoners are to be given a small sum of money, transportation to a designated place, and sufficient clothing for neat and comfortable appearance. If a prisoner has demonstrated that he is competent or proficient in any gainful trade, he shall also be given a certificate of competency in such trade signed by the proper authorities.

Sec. 7757 (5). Parole agents are to exercise supervision and authority over paroled prisoners and those who are to be paroled in finding and retaining self-supporting employment, and in promoting rehabilitation work with paroled prisoners to the end that they may become law-abiding citizens. They shall assist such parolees in every possible way toward compliance with the conditions of the parole.

Oregon. 8 Comp. Laws Ann. (1940) sec. 127-125. Paroled convicts may be employed by the superintendent of the penitentiary to work at any wood camp cutting wood for use at the state institutions. Wages shall be reasonable and not exceed "wages ordinarily paid to free labor."

Sec. 26-23I I a. "The state forester is hereby authorized to employ persons, who are paroled from the Oregon state penitentiary, in forestry camps established by the state forestry department for making fire trails, prevention of forest fire hazards, planting trees, and such other service in connection with the administration of the laws relating to forests and forest fires as the state forester in his discretion shall determine. The persons so employed shall be paid from funds available for the use of the state forestry department not to exceed $\$ 30$ per month, and shall also receive their board and lodging while so employed." 
Sec. $26-23 \mathrm{I}$ b. Persons employed shall be those who are "mutually agreed upon by the state parole board and the state forester. Such employees shall be responsible to the state forester for their conduct while under his employ and supervision, and the state forester shall report to the parole board any failure on the part of such parolees to comply with the rules of conduct established by the state forester."

Rhode Island. Gen. Laws (1938) ch. 619, sec. 6. The chief of the division of probation and any probation officer "in whose custody any female has been committed by the court may provide for the care of such female . . . whenever in the opinion of such chief the moral improvement and welfare of such female will be promoted thereby, and such care and maintenance shall be for such period as said chief shall deem advisable, and the care and maintenance of such females under the age of twenty-one years shall be paid for by the state at a rate of not exceeding $\$ 5$ per week for each such female."

South Dakota. Code (1939) sec. 13.5309. Parolee is given suitable clothing not to exceed $\$ 15$ in value and necessary traveling expenses not to exceed $\$$ Io.

Sec. I 3.5304. It shall be the "special duty" of the parole officer to secure employment and homes for all persons paroled or discharged from the penitentiary as far as practicable and "by his counsel and encouragement aid in their reformation."

Tennessee. Michie's Code Ann. (1938) sec. 1178r. The commissioner of institutions is authorized to collect $\$ 2$ per month from each paroled prisoner to be used in the maintenance of a "follow up" system for said prisoners.

Sec. II 783 . Field agents appointed by the commissioner of institutions to visit the parolees, their places of employment, and determine whether the prisoners are observing the terms of their parole and whether they are being "honestly and fairly treated by their employers. . . ."

Secs. I I 784 and I 785 . Commissioner of institutions may collect one-third of paroled prisoner's earnings to be kept until he is given a final discharge, when it is returned to him. In case of sickness or 
urgent need of the prisoner or his dependents these earnings may be paid to the prisoner at the discretion of the commissioner.

Texas. 17 Vernon's Civil Stats. (1925) art. 6203 (10). "Upon the discharge of any prisoner upon parole . . . such person so paroled, shall be furnished by the proper officers of the State Prison Board with such clothing as is usually furnished to prisoners upon discharge from prison in this State together with a railroad nontransferable ticket from the place of his discharge to the place of his conviction and sentence, and in addition thereto, the sum of $\$ 5 . "$

Utah. 5 Code Ann. (1943) sec. 85-9-58. "When a convict shail be discharged from prison by pardon or otherwise, the warden shall furnish him with clothing, if he is not already provided for, not exceeding $\$$ Io in value, and such sum of money, not exceeding \$ro, as the warden may deem necessary and proper, provided the prisoner has less than $\$$ ro of his earnings to his credit. The board may in its discretion furnish such convict with a further sum of money, not exceeding $\$ 15$, whenever in its opinion the necessities of the convict are such as to require the same. Instead of paying to a discharged convict the sum of money as above allowed, the warden may in his discretion expend the money and allowance, or such portion thereof as may be necessary, in paying the fare of the convict to his home or place of destination."

Vermont. Pub. Laws (1933) sec. 8877. "When a person has been placed on probation" the probation officer is authorized "to expend for such person's temporary support or traveling expenses, or for both such purposes, such reasonable sum as the court may deem expedient. . . . (This evidently applies to persons put on probation by the court. There is no mention of help to those paroled from the penitentiary.)

Washington. Io Remington's Rev. Stats. Ann. (1932) sec. 10222. Each convict when he leaves the penitentiary "in case the prisoner has not funds sufficient for present purposes," shall be furnished with $\$ 5.00$ in money, a suit of clothes costing not more than $\$ 10.00$, and a railway ticket which must be used within twenty-four hours. 
Wisconsin. Stats. (194I) sec. 57.075. A fund shall be created out of funds belonging to absconded probationers. "Said funds shall be used to defray the expenses of clothing or other necessaries, and for transporting probationers who are without money or other means to secure the same. . . . "Such funds shall be re-collected from such probationers whenever possible.

Mason's Wisconsin Annotations, sec. 57.06. "Board of Control may furnish medical care to paroled prisoners under certain circumstances. 25 O.A.G. $488 . "$

Wyoming. Rev. Stats. (1931) sec. 108-819. All moneys received from fines for misconduct of prisoners while in the penitentiary shall go to a fund to be used "as a special aid to discharged and paroled prisoners, who are infirm or in any way incapable of earning a sufficient subsistence after their release."

Laws (I94I) ch. 86, sec. 7. Probation and parole officer "shall use all practicable and suitable methods . . . to aid and encourage persons on probation or parole and to bring about improvement in their conditions and conduct."

Federal. I 8 U.S.C.A. secs. $720,72 \mathrm{I}$. It is the duty of parole officers "to aid paroled prisoners in securing employment and to visit and exercise supervision over them while on parole." It is the duty of the warden to furnish paroled prisoners with "clothing, transportation, and $\$ 5$ in money." 


\section{Appendix $\mathrm{M}$}

\section{Assistance to Persons Discharged from Custody}

7 HOUGH active assistance to persons released on parole is but slight, such assistance to persons who have

1 been wholly discharged appears to be non-existent. The states generally have provision for transportation to the place of conviction or locality of residence; they provide a certain maximum of clothing and a small sum of money. An occasional statute gives them assistance in finding employment at the time of discharge. But what happens to the released convict between the time of his release and his next appearance in court is evidently not a matter of legislative concern. Private agencies may, and do, assist him to live within the law; but no legislation, except that of California, and possibly Massachusetts, imposes on state officials any particular care of released convicts in their efforts to go straight.

Alabama. Code (1940) tit. 45, sec. 54. Each prisoner on discharge to be furnished with suit and money to reach destination, not exceeding $\$$ I 0 .

Tit. 45 , sec. 55. In addition, if sentence did not exceed five years, to be given $\$ 10$; if over five years, $\$ 10$ and $\$ 2$ for each year or major fraction thereof.

Arizona. 3 Code Ann. (1939) sec. 47-120. The parole clerk (apparently of the board of pardons and paroles) "shall aid in securing proper employment for all paroled prisoners, and also for those who have been discharged before the maximum time for which they were sentenced. . . ."

California. Penal Code (1941) sec. 2945. "The board shall have power and authority to provide for assisting discharged prisoners and to secure employment for the same and for that purpose they 
may employ necessary officers and employees, may purchase tools, and give any other assistance that, in its judgment, it deems proper for the purpose of carrying out the objects and spirit of this act."

Codes, Gen. Laws and Const. (I941 supp.) Welfare and Institutions Code, secs. I710, 1760. The Youth Correction Authority is empowered, within the limits of its budget, to establish "agencies and facilities designed to aid persons who have been discharged by the Authority from its control in finding employment and in leading a law-abiding existence."

Penal Code (I94I) sec. 2946. The board of paroles may draw money for aiding discharged convicts in the amount of $\$ 1000$ without submitting vouchers and the amount shall be replenished from appropriations made for the support of the board.

Colorado. 4 Stats. Ann. (1935) ch. 13r, sec. 86. "When any convict is discharged from the penitentiary he shall be furnished the sum of ten dollars; also, when the said convict is in need, he shall be furnished with a new suit of common clothing, and all articles of personal property belonging to said convict that may have been turned over to the warden."

Connecticut. Gen. Stats. (1930) sec. 1983. Any person in state prison deemed worthy by board of directors, on recommendation of warden, shall receive $\$ .15$ a day for services performed by him, as maximum.

To be kept in bank, etc., and given him on discharge, or warden may pay it to prisoner's dependents.

Florida. Stats. (1941) sec. 954.32. "Each convict who serves a sentence at hard labor in the State penitentiary shall be furnished, when discharged, at the expense of the State, one good suit of clothes, a hat and one pair of shoes, and be furnished with five dollars to provide the necessities of life until he can procure work."

Idaho. I Code Ann. (1932) sec. 20-421. When any convict is discharged from the penitentiary, the warden shall furnish him with a decent suit of clothing (if he is not already provided for) at the expense of the state, and shall pay each convict, from any funds belonging to the penitentiary, a sum not exceeding fifteen dollars and 
shall deliver to said convict any property received from him which has not been disposed of according to law.

Illinois. Ann. Stats. (1935) ch. 108, sec. 2 I. (Jones Ann. Stats. 99.0I3.) Money and property brought to prison shall be returned to convict on discharge and department of public welfare shall "furnish each convict who may be discharged from the penitentiary, by pardon or otherwise, with a suitable suit of citizen's clothing, and shall also furnish such convict with transportation to the place of his conviction, or the equivalent thereof in money, and in addition thereto the sum of $\$ \mathrm{I}$, for other necessary expenses of such convict."

Indiana. 4 Stats. Ann. (1933) sec. 13-254. "The warden of each prison shall appoint an agent, whose duty it shall be to aid and secure proper employment for all prisoners who have so conducted themselves as to be entitled to go out from such prison on parole, and also for those who have become entitled to an absolute discharge before the maximum time for which they were sentenced, and to keep the said warden informed of the conduct of said prisoners when out upon parole, and to make a report as to each prisoner in such matters on the first day of each month for the preceding month."

Sec. 13-257. "Hereafter, whenever any person shall be discharged from the Indiana Reformatory or the Indiana State Prison, the superintendent or warden thereof shall procure for him and deliver to the proper railroad conductor, a railroad ticket to any point to which such person may desire to go, not farther from said prison than the point from which he was sentenced, give him \$IO in money, a durable suit of clothes, and, from the first day of November to the first day of April, an overcoat. The suit of clothes shall not cost to exceed $\$ 6$ and the cost of the overcoat shall not exceed \$5."

Sec. 13-413. "It shall be the duty of the general superintendent (of reformatory) to appoint an agent to aid, and secure, if possible, proper employment for all prisoners who have so conducted themselves as to be entitled to go out from said reformatory upon a parole, and also for those who have become entitled to an absolute discharge before the maximum time for which he was sentenced."

Iowa. Code (1939) sec. $373^{6}$. Duty of superintendent of women's reformatory "so far as practicable, to obtain for each inmate be- 
fore she is paroled or discharged a home and suitable employment if they are not otherwise provided."

Sec. 3737. Superintendent of women's reformatory may, "with the consent of the board of control, furnish a discharged or paroled inmate with proper clothing, and a receptacle therefor, and transportation to her place of employment, or home, or other place not more distant than the place of commitment, and a sum of money not exceeding $\$ 25 . "$

Sec. 3779. "When a prisoner is discharged the warden shall furnish him, at the expense of the state, with a railroad ticket to the point in the state nearest his home or to any point of a like distance without the state, a suit of common clothing, and not more than $\$ 25$, an account of which shall be kept by the warden."

Maine. Rev. Stats. (1930) ch. 152, sec. 53. "On the discharge of any convict who has conducted himself well during his imprisonment, the warden may give him from the funds of the prison a sum not exceeding ten dollars, and, if he requests it, a certificate of such good conduct; and shall take care that every convict, on his discharge is provided with decent clothing."

Massachusetts. 4 Ann. Laws (1933) ch. I27, sec. 158. Male parole agents who are employed to aid discharged male prisoners shall endeavor to secure employment for them, to provide them with needed assistance, and to perform such other duties relative to discharged prisoners as the commissioner of corrections requires.

Sec. I 59. Women agents are to counsel and advise female prisoners who have been discharged, assist them in obtaining employment, and under the direction of the commissioner, render them pecuniary aid.

Sec. I6o ff. The commissioner may expend such sum as is annually appropriated for the assistance of prisoners released from the state prison or other institutions. Money may be spent in furnishing clothing, board, and tools. Discharged prisoners may be given up to $\$ 10.00$ in money. Sec. 164 authorizes certain officials to provide prisoners released from county prisons with such an amount of money as in their opinion can be wisely used to encourage their reformation.

Michigan. 3 Comp. Laws (1929) sec. 17604. (Mich. Stats. Ann. $\$ 28.143$ I.) When a convict is discharged, the warden shall 


\section{8}

THE PREVENTION OF REPEATED CRIME

furnish him with clothing if he be not already provided therewith, not to exceed $\$ 25.00$ in value, and such an amount of money between $\$ 10.00$ and $\$ 25.00$ as the warden believes proper. The warden shall also buy him a ticket to some designated point in the state. An attendant shall put the convict on the train and give the ticket to the conductor.

Minnesota. 2 Mason's Stats. (1927) sec. 10796. The warden shall furnish discharged prisoners with one good serviceable suit of clothing and underclothing, and if the release be between October I and March $3 \mathrm{I}$, a good serviceable overcoat, and to each convict, when released, $\$ 25.00$ in money. Sec. 10838 . Similar provisions concerning discharge from the state reformatory.

Missouri. 2 Rev. Stats. (1939) sec. 9047. The commission shall furnish to each convict upon discharge a suitable suif of clothes, including a hat and shoes of the value of \$10.00, if the discharge is between the first day of April and the first day of October, or of the value of \$15.00 if the discharge is at another time. The discharged prisoner shall also be given a sufficient sum of money to transport him to the county from which he was sentenced.

Sec. 9049. The sum of not less than $\$ 25.00$ shall be allowed to accumulate for the use and benefit of each prisoner after release, unless 5 per cent of the earnings of said prisoner during the period of confinement amounts to less than $\$ 25.00$.

Montana. 5 Rev. Codes (I939) sec. I2458. When a convict is discharged from imprisonment, the warden must provide him with proper and sufficient clothing at a cost not exceeding $\$ 25.00$, and in addition $\$ 5.00$ in money.

Nebraska. Comp. Stats. (1929) sec. 29-2627. The warden shall provide discharged convicts with $\$ 10.00$ in money and transportation to some designated place within the state.

Sec. $83-929$. The warden shall also furnish discharged convicts with a decent suit of clothes and an overcoat if he is discharged between the first of November and the first of April, if he does not already have an overcoat, and shall give him $\$ 10.00$ and a Bible if he can read. 
New Hampshire. Rev. Laws (1942) ch. 464, sec. 17. The warden may furnish discharged prisoners with a suit of clothes, decent and suitable for the season in which he is discharged, and not more than $\$ 10.00$ in money.

New Jersey. I Rev. Stats. (1937) sec. 30:4-I I4. The state board has power to furnish discharged convicts with not more than $\$ 25.00$ in money.

New Mexico. Stats. Ann. (1941) sec. 42-1 708. The superintendent shall provide released convicts with suitable clothing, $\$ 5.00$ in money, and transportation to a designated place.

New York. IoB McKinney's Consol. Laws Ann. (1938) sec. 125. The warden shall give each discharged prisoner necessary clothing not to exceed during the winter months $\$ 40.00$ in value, $\$ 20.00$ in money, and a railroad ticket to a place at no greater distance than the place of conviction.

North Carolina. Code Ann. (1935) sec. 7757 (20). Discharged prisoners shall be given a small sum of money, transportation to a designated place, and sufficient clothing for neat and comfortable appearance. If a prisoner has demonstrated during his prison service that he is competent or proficient in any gainful trade, he shall also be given a certificate of competency signed by the proper authorities.

North Dakota. Comp. Laws (1913) sec. II226. Discharged convict shall be provided with a decent suit of clothes, a sum of money not to exceed $\$ 5.00$, and transportation to the place where he received sentence.

Oklahoma. Stats. (1941) tit. 57, sec. 139. "When any convict shall be discharged from prison, by pardon or otherwise, the Warden shall furnish him with clothing not to exceed $\$$ ro in value, if he be not already provided with clothing; not to exceed $\$$ Io to buy a railroad ticket for such prisoner to his home or place of destination, provided said prisoner be sentenced from any county except the county in which the penitentiary or reformatory is located; the Warden shall furnish such prisoner with $\$ 5$ in money, provided, said prisoner has not as much as $\$ 5$ to his credit." 


\section{Oregon. 8 Comp. Laws Ann. (1940) sec. 127-106. "Upon} the discharge or parole of any convict from the penitentiary, it shall be the duty of the warden to see that such discharged or paroled convict is properly clothed, and in all cases where a convict is finally discharged it shall be the duty of the warden to pay such discharged convict the sum of $\$ 5$. . . ."

Laws (1939) ch. 443, sec. I. Authorizes the appropriation of $\$$ I 500 annually for the following purpose:

Sec. 2. "The warden of the state penitentiary hereby is authorized to expend the said moneys in providing travel assistance for indigent discharged convicts at the time of release, when he shall deem it necessary and advisable. Such assistance may be furnished only in any such case to provide in whole or in part for the expense of travel of any such person from Salem to a destination within or without this state, and at a cost to the state, as shall be approved by the state parole board; but no transportation shall be furnished in a form redeemable by other than the state of Oregon, and no allowance for meals shall exceed the rate of $\$ 1.00$ for each six hours necessarily required for making such travel."

Pennsylvania. Purdon's Stats. Ann. (I930) tit. 61, sec. 375 . "Whenever a convict shall be discharged, by the expiration of the term for which he or she was condemned, or by pardon, he or she shall take off the prison uniform, and have the clothes which he or she brought to the prison restored to him or her, together with the other property, if any, that was taken from him or her on his or her commitment, that has not been otherwise disposed of.

"When a prisoner is to be discharged, it shall be the duty of the warden to obtain from him or her, as far as is practicable, his or her former history; what means of literary, moral or religious instruction, he or she enjoyed; what early temptations to crime, by wicked associations or otherwise, he or she was exposed to; his or her general habits, predominant passions and prevailing vices, and in what part of the country he or she purposes to fix his or her residence, all which shall be entered by the clerk in a book to be kept for that purpose, together with his or her name, age, and time of discharge.

"If the Board of Trustees and warden have been satisfied with the morality, industry, and order of his conduct, they shall give him a 
certificate to that effect, and shall furnish the discharged convict with $\$ 4$, to be paid by the state, whereby the temptation immediately to commit offenses against society, before employment can be obtained, may be obviated."

Sec. 376 . The above act shall be modified so, "that hereafter the Board of Trustees and warden may, if they think it expedient, furnish to a discharged convict any sum not exceeding \$IO, out of the annual appropriation made by the state for that purpose."

Rhode Island. Gen. Laws (1938) ch. 55, sec. 29. "Whenever a convict shall be discharged he shall be decently clothed, and the chief of the division may in his discretion pay to him a sum of money not exceeding one-tènth of his actual earnings while confined in said prison: Provided, however, that in case of sickness of any convict by which he shall have been incapacitated for labor, he shall, in the discretion of said chief, be paid a sum not exceeding one-tenth of the average compensation of convict labor in said prison during the time of his sickness; provided, moreover, that the said chief may pay said amount at any time during the imprisonment of the convicts to the families or near relatives of such convicts, who may be in circumstances of indigence or want, instead of paying it to the convicts themselves at their discharge; and provided, further, that in no case shall the sum paid such convict at his discharge be less than $\$ 5$."

South Carolina. I Code of Laws (1942) sec. 1978. Discharged convict furnished with suit of clothes if necessary and transportation from penitentiary to his home.

South Dakota. Code (1939) sec. 13.4726. "Every convict when discharged shall be provided with a suitable suit of clothes, a sum of money not to exceed $\$ 5$, and transportation to the place where the convict received sentence. He may also be allowed employment in the Penitentiary under the rules established for the government of convicts, for such period of time and such rate of compensation as the Warden shall deem proper and equitable."

Tennessee. Michie's Code Ann. (1938) sec. 12145. Each convict, if he has none, shall be furnished with decent clothing and a maximum of $\$ 10$ to reach his home. This is done at the discretion of the commissioner. 
Sec. 1025. The Tennessee Association for the Relief of Ex-Convicts of the state of Tennessee is created. Purposes are to get in touch with discharged convicts, "give such encouragement as is possible toward helping to secure a proper attitude towards society," help them get employment, give financial aid when necessary, and keep in touch with them for at least a year and "exert every effort possible toward making them law-abiding citizens."

Texas. 17 Vernon's Civil Stats. (1925) art. 6166z1. "When a prisoner is entitled to a discharge from prison, he or she shall be furnished with a written or printed discharge from the manager, with the seal affixed, signed by the manager, giving the prisoner's name, date of sentence, from what County sentenced, amount of commutation received, if any, the trade he has learned, if any, his proficiency in the same, and such description as may be practicable. Such discharged person shall be furnished with a decent outfit of citizen's clothing of good quality and fit, and two suits of underwear; and when a person and/or convict actually serves over one year, he shall receive $\$ 50$ in money in addition to any money held to his or her credit; provided that if a person and/or convict does not actually serve one year flat time, he shall not receive $\$ 50$; but in lieu thereof a person serving less than one year actual time shall receive $\$ 25$ in money in addition to any money held to his or her credit and a decent suit of citizen's clothing and two suits of underwear, provided that if the actual time served exceeds ten years, the sum of money shall be $\$ 75$, and if the actual time served exceeds twenty years, the sum of money shall be \$100. As far as may be practicable the Prison Board may authorize creation of a Bureau for the purpose of placing discharged prisoners in connection with employment, provided such will not be an extra expense to the prison system."

Utah. 5 Code Ann. (I943) sec. 85-9-58. "When a convict shall be discharged from prison by pardon or otherwise, the warden shall furnish him with clothing, if he is not already provided for, not exceeding $\$ 10$ in value, and such sum of money not exceeding $\$$ ro as the warden may deem necessary and proper, provided the prisoner has less than $\$ 10$ of his earnings to his credit. The board may in its discretion furnish such convict with a further sum of money, not exceed- 
ing $\$ 15$, whenever in its opinion the necessities of the convict are such as to require the same. Instead of paying to a discharged convict the sum of money as above allowed, the warden may in his discretion expend the money and allowance, or such portion thereof as may be necessary, in paying the fare of the convict to his home or place of destination."

Vermont. Pub. Laws (1933) sec. 5520. "The warden of the state prison and the matron of the women's reformatory, in their discretion, and at the expense of the state, may furnish persons discharged from their institutions with railroad tickets to their homes. Such tickets shall be delivered to the conductor of the train, who, at the end of his route, shall deliver the unused portion thereof, if any, to the discharged person."

Sec. 8816. Each prisoner for good behavior and if "he is poor and destitute, shall be entitled to receive one dollar for each such month (of good behavior) when finally discharged . . . but such payment shall not exceed one hundred dollars."

Virginia. Code Ann. (1942) sec. 502 1. Prisoners may get $\$ 10$ upon discharge, also proper certificates of transportation, and a coarse suit of clothes if necessary.

Washington. Io Remington's Rev. Stats. Ann. (1932) sec. 10222. Each convict leaving the penitentiary shall be given the money he brought with him, any sum earned or presented to him, and in case he has insufficient funds he shall be given $\$ 5$, a suit of clothes costing not more than $\$ 10.00$ and transportation by the cheapest route to the place sentenced, such transportation to be void if not used in twenty-four hours, and he shall be entitled to immunity from having his hair cut or having been shaved for three months prior to his release.

Wisconsin. Stats. (I94I) sec. 53.1 5. "Every convict, when discharged, shall be provided with a decent suit of clothes and a sum of money, not to exceed $\$ 5$, in addition to transportation, or the means to procure the same, from Waupun to any place within this state, which the warden may, at his discretion and as necessity may seem to require, furnish; and may also be allowed employment in the prison, under the rules established for the government of convicts, 


\section{THE PREVENTION OF REPEATED CRIME}

for such period of time and at such rate of compensation as the warden, under the direction of the state board, shall deem proper and equitable."

Wyoming. Rev. Stats. (1931) sec. 108-820. “. . . state board of charities and reform shall provide a prisoner upon his or her final discharge, as a gratuity, $\$ 15$ in cash, a railroad ticket to any point within a radius of 750 miles from the place of his or her confinement, either within or without the state, such ticket to be delivered only to the conductor of the train upon which the released prisoner is to travel, and suitable clothing when necessary; provided, however, that the total value of gratuities allowed shall not exceed the sum of $\$ 50$ unless by the order of the state board of charities and reform. . . ."

Federal. 18 U.S.C.A. secs. 746, 819, 840. Discharged prisoners are to be furnished transportation to their place of residence, or place of conviction, or to some other place within the United States approved by the Attorney General, and, if their term of imprisonment has been six months or more, they are to be given suitable clothing and not more than $\$ 20.00$ in money. 


\section{Appendix $\mathrm{N}$}

\section{Assistance Actually Rendered}

$S$ pointed out in Appendices $L$ and $M$, some of the stat-
utes specify that "assistance" in leading law-abiding
lives shall be rendered to paroled and discharged convicts, and in others the permission to render active aid is implicit. What is definitely absent from the legislation is provision of the means for such assistance. In an effort to find out how much aid actually is given, specific inquiries were addressed to the heads of state parole organizations. The replies received indicate clearly that, however well intentioned those officials may be, the lack of means and facilities is such that real aid from state sources, as distinct from private organizations, is practically non-existent.

The inquiries were these:-

“2. When a prisoner is released at the expiration of his sentence, what effort is made by state officials-as distinct from private agencies - to get him a job?

" 3 . Is anything done, by the state, to provide help in finding new jobs, or to provide him with food and shelter until he can find self-supporting work?

"5. Is anything more done for persons who are paroled before the expiration of sentence than is done for those who are released only because the full term has been served?"

The replies received were as follows:

\section{Alabama.}

2 and 3 . There is no provision for efforts by state officials to secure employment for those prisoners released at the completion of sentences. There is in existence a combined state and federal project known as the State Employment Service wherein all unemployed including those released from penal institutions may register and are placed in and are called for work by this agency when openings occur. 
5. More is done for those people paroled before the expiration of sentence than is done for those released at the completion of sentence. All those released on parole are aided toward securing employment, and if they become unemployed while on parole, the parole officer is charged with the duty of attempting to locate employment. Such parolees are instructed to carry any and all problems to their parole officer, and this officer has full instructions to consult with the parolee during his supervision rounds on matters which might contribute to a rehabilitation of the subject.

\section{Arizona.}

2. None.

3. Nothing.

5. Generally prospective parolees are given positions of trust for a period prior to release.

\section{California.}

2. Before being released on parole a prisoner must have employment which meets with the approval of the state parole officer. Jobs are not secured by state officials. Discharged men do not require jobs.

3. The state does not provide help in finding new jobs. There is a fund for the aid of discharged and for old men, providing they have no other means of support.

5. No. No distinction is made between paroled and discharged men.

\section{- Delaware.}

2. None by state officers.

3. Nothing except through the medium of the state parole board.

5. The paroled prisoner is assisted in securing employment and a home.

\section{Florida.}

2. Only occasionally.

3. No.

5. No.

\section{Idaho.}

2. Very little. The state parole officer (there will be two after May 8) sometimes is able to secure employment for a man. Neither is there any recognized private agency carrying on such work. 
3. Nothing more than number one above. ( 1 . An outgoing prisoner receives $\$ 15$ in cash and the warden spends not to exceed $\$ 15$ in seeing that he is clothed.)

5. There is no particular distinction in furnishing assistance as between parolees and those who complete their terms.

Illinois.

2. Usually no effort.

3. There is nothing done.

5. Yes, in a great majority of cases in Illinois. (The gist of the reply is that since the statute requires that before release they must have a home, sponsor, and employment free from criminal influence, the board assists them in finding such a set-up.)

\section{Indiana.}

2. When a prisoner is released at the end of his sentence no effort is made by state officials to get him a job unless he asks for such assistance. This happens infrequently. In some cases, however, both the institution officials and this department do assist in finding employment for discharged men.

3. Nothing is done by the state to provide help in finding new jobs or to provide him with food and shelter until he can find selfsupporting work other than has been described above. Naturally he has access to the state employment service. I feel sure that any one in our organization would assist such a man if he asked for assistance, but certainly no effort is made to get him to ask for it.

5. If the prisoner cannot propose a satisfactory home, sponsor and employment, then this department undertakes to secure these for him and he is not released until they are secured.

Kansas.

3. Persons released on parole must have employment or support. If the parolee or his relatives or friends have been unable to secure such employment he is held until such time as the parole officer is able to properly place him. The parole officer personally checks or receives regular reports from parolees under his supervision. In case any one of his parolees is having difficulty with his job or loses it, the parole officer does all in his power to secure reemployment for him. (Though the reply does not specifically so state, apparently nothing is done for the person released because of expiration of sentence.) 
Kentucky.

2. Upon release at the end of the sentence, the state does nothing per se, but the warden or some of the employees may and frequently do render personal help in getting the person released a job.

3. To provide help in finding new jobs, or to provide the released person with food and shelter until he can find self-supporting work, the state makes no provision.

5. (The gist of this reply is that the state requires a person to have a job before release on parole and that officials help him to find it.)

\section{Louisiana.}

(The gist of the reply is that the Department of Public Welfare has been substituted for the Board of Parole. The Department is not responsible for prisoners who have been released from the penitentiary at the expiration of their full term. When a prisoner makes application for parole "he frequently has a definite plan at the time he makes his application and in almost every case he has a promise of employment. This employment is usually secured for him by his sponsor or first friend. The investigation of the parole is made by employees of this department who contact the persons who know the applicant for parole. In this work, plans for the employment for the parolee are determined. If the parolee is eligible for public assistance, this may be provided by the Department of Public Welfare." "Employment is a prerequisite of parole, but there is no organized or routine help available to the prisoner who has served his sentence and is receiving his full discharge. In a few instances prison officials are able to assist the man who is being discharged, or put in his way opportunities for employment, but only in a few.")

Maine.

2. If paroled, every possible effort is made to procure employment for him, but this is not so if he is discharged.

3. If paroled, he is assisted in finding employment before parole and at any time during his parole period, but no provision is made for providing food and shelter.

Maryland.

2. The state parole department has no employment service but, in case of prisoners approved for parole, assists in the obtaining of 
satisfactory jobs through the state employment service, community. placement bureaus, and by a limited amount of employment contacts made by parole officers.

3. In case of prisoners approved for parole, the parole department, in addition to assisting in an arrangement for jobs as set forth above, refers worthy cases to the Prisoners Aid Association of Maryland for maintenance until satisfactory employment is arranged.

5. The division of parole does no work for prisoners who are released by expiration of sentence. The Prisoners Aid Association of Maryland, a private agency, does considerable work with such released prisoners.

\section{Massachusetts.}

2. When a man is released, having served his maximum time, there is not very much done for him in the way of assistance. In fact, we have found that a man who has served his full time shows very little initiative or interest in allowing us to be of any help to him, so I would say the assistance given to such men is very little.

3. When a man is released on parole in this state he comes out on an approved home and job. The jobs are procured through the efforts of the parole officers in the respective district in which the man is going to live.

5. There is decidedly more assistance given to men on parole than to those who have served their full time and leave the institution without parole supervision. - . . Besides the various relief agencies, a great deal is done through our employment program which has been set up, wherein the parole officers devote one-half day each month in contacting the various employers of help in districts assigned to them, and in this way acquaint the employers with the capabilities of some of their men.

\section{Michigan.}

2. The prison officials and the parole and probation officials do everything possible to find employment for former inmates. However, there are no funds available with which to provide former inmates with food and shelter until they can find self-supporting work.

3. Each inmate is required to have an approved work and home contact prior to his release from the institution on parole. The in- 
mates have to do most of the work in finding the jobs, but our parole officers are doing very fine work in placing these men in private industry and on farms. The parole office has a small fund from which money is loaned to parolees to tide them over the rough spots, but this fund is very small and not nearly enough to be of much help.

5. Should a person serve his maximum sentence and leave the prison on a discharge, we have lost all jurisdiction over him, and consequently have no further contact with him. Prisoners who have been discharged from prison are given every assistance by parole and prison officials if and when needed.

\section{Minnesota.}

2. When a prisoner is released by expiration of sentence usually no effort is made by state officials to secure employment for them. There may be exceptions to this statement, but whatever action is taken is purely voluntary on the part of the person who helps the prisoner.

3. Nothing whatsoever is done by the state. The $\$ 25$ plus any savings that the prisoner may have made from his earnings at the institution is what he must rely upon until he can find self-supporting work.

5. When released on parole, persons are not permitted to leave the institution until a bona fide job has been located.

Mississippi.

2. No effort is made to secure work for him.

3. Nothing.

5. The Governor in granting suspensions or paroles usually requests those securing suspensions for a prisoner to guarantee employment.

Missouri.

2. (Nothing is done for the few who are kept in confinement until the end of the term.)

5. If the subject is released on parole he must have employment before he is released, or at least be assured of maintenance in a home. - . Every effort is made to see that their employment situation is satisfactorily taken care of. . . . Should one be released with no additional funds and no job we have an agency in St. Louis 
and one in Kansas City which will give temporary assistance to such people. Our probation and parole officers exert every effort to properly place the fellow in a job.

Montana.

2. No attempt is made to secure work for a released prisoner.

3. No.

5. No.

\section{New Hampshire.}

2. State parole officer assists in finding a job.

3. A small fund is provided by the state for this purpose.

5. Yes. (The answer does not say in what respect.)

New York.

2. Every indeterminate-sentence inmate released in this state must have a job prior to such release. If he loses this after he becomes a parolee, we have an employment bureau which attempts to place these men. In addition, we have just secured the services of an additional employment man to attempt to make inmate placements for those men who have exhausted their own resources and who would be released except that they have been unable to get work. - . So far as I know the Department of Correction does not take responsibility for after-care of men who have served their maximum. But should some of them voluntarily come to us we would of course give them what service is possible. At least we could refer them to agencies equipped to deal with the particular problems presented.

\section{Ohio.}

2. Apparently nothing is done for persons automatically released at expiration of the sentence in the way of finding a job. Generally before he is released on parole we try to have definite employment or work already lined up for him. However, if he does not already have a definite job, our parole officers aid and assist him in securing work as soon as possible.

3. Those who are paroled from our institutions are not permitted to leave the institution until they do find a sponsor or some one who is willing to provide food and shelter until he can find self-supporting work. 


\section{2 THE PREVENTION OF REPEATED CRIME}

5. Both groups are treated practically the same.

\section{Oklahoma.}

2. When he is so released, nothing is done by the state to aid him in finding employment.

3. No provision is made by this state to aid a released prisoner in finding a new job, or to provide him with food and shelter until he can find self-supporting work, except the usual relief agencies.

5. Nothing more is done for persons who are paroled before the expiration of sentence than is done for those who are released only because the full term has been served, except that by the conditions of their parole they are required to report in writing to this office once each month.

\section{Oregon.}

2. The State Board of Parole and Probation endeavors to secure employment for those men who have been ordered paroled and have not been successful in obtaining employment themselves or through their relatives and friends. In this connection the State Parole Department has working agreements with the Federal and State Employment Offices, the State Welfare Commission, and the Works Progress Administration for the securing of employment.

3. The State Board of Parole and Probation lends its efforts toward the finding of employment for either a discharged prisoner or one who has previously been released on parole who has lost his job. Our efforts however are limited solely to service and we have no capital expenditure provided to provide temporary relief. However, our experience has been that the welfare office and the Red Cross and the Salvation Army have adequately met all emergency demands.

5. While the State Parole and Probation Department is willing to help prisoners who have completed their maximum sentences, the call upon us in this connection has been very small. Our efforts to secure employment is mainly for those men who have been ordered paroled or are on parole. There is no rule, regulation, or law to this effect, but this seems to be the way it works out from a practical standpoint. The man who is discharged does not make his wants or needs known to State officials, and we know not whence he goes after he is released. 


\section{Pennsylvania.}

2. Before a release on parole is effected, it is necessary that the prisoner have a suitable employment plan. In the event he is unable to procure employment through the efforts of relatives or friends, agents of the Department of Justice make suitable contact and do in a great number of cases obtain employment.

3. If a discharged prisoner is unable to adequately take care of himself between jobs or in finding a new job, our agents assist. If he is without funds, money is advanced to him and shelter provided for.

5. Wholly discharged prisoners and paroled prisoners are accorded equal treatment.

\section{Rhode Island.}

2. An inmate serving full time is a free lance on discharge and no effort is made at present to secure employment for him. However, an inmate seeking parole must have legitimate employment to go to when paroled. In some cases the Division of Probation and Parole aids him in this respect.

3. No effort is made to provide employment, food or shelter for indigent ex-inmates. However, there are two bills pending in our State Legislature to provide for proper care and supervision of this type of inmate on discharge.

5. Much is done for parolees during their period of supervision, such as-aiding them in making proper social adjustment, retaining employment, etc. Inmates discharged at expiration receive no supervision of any kind.

South Carolina.

2. No Provisions for Employment Service.

3. Not Directly by State.

5. No.

\section{South Dakota.}

You will be interested to know that a group of inmates of the state penitentiary has recently formed an "Employment Advisory Council." The purpose of the Council is to secure the cooperation and support of state officials, judges, civic, social, fraternal and religious organizations in an effort to aid the released prisoners in rehabilitating themselves. The Council suggests that each organization might act as a 
sponsor for one man who will be released, obtain a job for him in his line of work and appoint one member of their organization to act in an advisory capacity to whom the man could turn for advice should problems arise.

2. Nothing.

3. No.

5. Yes, it is necessary for an inmate to have a job before being released on parole.

Texas.

2. When he is so released no effort is made by state officials to get him a job.

3. Nothing is done by the state to provide help in finding jobs, or to provide him with food and shelter.

5. Persons who are paroled before the expiration of sentence are furnished an outfit of clothes, a ticket to the place of conviction and five dollars in money. Such persons are required to report to the Voluntary County Parole Board of the County where he will reside. Prisoners are generally required to have a promise of employment before being recommended for parole. Persons who because of lack of outside contact are unable to secure employment before release are assisted in that matter by the County Parole Boards.

\section{Washington.}

2. The State, through the supervisors of this Department, makes every effort to secure employment for parolees. They contact industries, farmers and employees generally and certain church workers also render valuable assistance.

3. The State makes no provision to provide help except by the help of our parole supervisors who attempt to find suitable employment for them.

5. Our efforts toward help in the way of securing jobs is directed in behalf of parolees only, for we find persons who have served their maximum, seldom, if ever, request or expect any help from the State or our Department.

\section{West Virginia.}

2 and 3. West Virginia has no means whereby prisoners being released at the expiration of their sentences may have jobs awaiting 
them. Our Probation and Parole Officers, of which there are now eight, do endeavor to find employment for those under their supervision. In the event the officers can aid those released, they do so, but not many call upon them for their services.

5. As promptly as possible the Probation and Parole Officer investigates cases assigned to him and sends in his report to the Director of Probation and Parole. In these reports are given the prisoner's background, future outlook, home, employment, etc. If, in the Director's opinion, the case presents a proper outlook for parole, the Director then passes the case, with his recommendation, to the Governor for his signature. If the Governor signs the release order, it is then forwarded to the Parole and Record Clerk at the institution at Moundsville. There the prisoner is given supervision report forms for his use during the parole period. The Probation and Parole Law provides that the parolee shall be on parole for his maximum sentence. $\mathrm{He}$ is under supervision of one of the Probation and Parole Officers during that time and reports to him at regular intervals.

In most instances, our parolees have employment before they are released. This is the work of the Probation and Parole Officers. In the event a prisoner is released without a job, then his supervising officer contacts him and discusses with him the type of work for which he is best qualified. Every effort is made to find such work. The parolee is advised prior to his release that his supervising officer will aid him in any possible manner. He is to contact him immediately in the event situations arise which trouble him and which in some way may be the cause of his violating the conditions of his release.

\section{Wisconsin.}

2 and 3 . If a man is released by parole, of course, he would have to have a job before he can go out. He is encouraged to make every effort through friends and relatives and others to find a job, but in addition to that, the officers of the parole department do everything possible to secure a job for him. They have had considerable success along that line I must say. If a man goes out by way of discharge without parole, some effort is made on some occasions by the members of the probation and parole department of the state to also secure a job for the man. Their first effort is to find jobs for those that go out 


\section{I6 THE PREVENTION OF REPEATED CRIME}

by way of parole however, but in special cases they also are of help to men who go out by way of discharge. In fact, when a man inquires about it, it is always suggested that he go to the parole officer in his district and ask for suggestions and help even though he has been finally discharged.

5. A great deal more is done for persons who are paroled than for those who stay here until the end of their sentence. After a man goes out on discharge, we have no hold over him and can only give him a little extra service when he specifically requests it. For those that go out on parole, however, there is the guidance and the backing and the help of a parole officer during the entire remaining part of their sentence.

\section{Wyoming.}

2. No particular effort.

3. If necessary, is cared for through County Departments of Public Welfare.

5. No. 


\section{Appendix $\mathrm{O}$}

\section{Prison and Relief Associations in the United States and Canada}

7 HESE organizations and their addresses are listed, partly to indicate the number of private agencies,

1 which is some measure of the importance of the work in crime prevention, and particularly because readers may think it desirable to seek further information from them.

Prison Association of California

Ferry Building

San Francisco, California

George P. Sanborn, Executive Secretary

Colorado Prison Association

$43^{I-433}$ Cooper Building

Denver, Colorado

Rollie W. Bradford, President

Connecticut Prison Association

State Capitol

165 Capitol Avenue

Hartford, Connecticut

W. C. Barnes, Executive Secretary

Prisoners' Aid Society of Delaware

3I 7 North Adams Street

Wilmington, Delaware

Rev. W. A. Vrooman, Secretary

Bureau of Rehabilitation

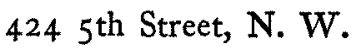

Washington, D. C.

Joseph E. Dayton, Director

Society for the Friendless

Nampa, Idaho

Rev. Earl C. Pounds 
Central Howard Association

608 S. Dearborn Street

Chicago, Illinois

Dr. F. Emory Lyon, Superintendent

Society for the Friendless

412 Youngerman Building

Des Moines, Iowa

Rev. Charles Parsons, Superintendent

Society for the Friendless

Frankfort, Kentucky

Rev. T. F. Taliaferro

Maine Prison Association

Portland, Maine

George E. Togg

Prisoners' Aid Association

3 Court House

Baltimore, Maryland

Howard C. Hill, General Secretary

United Prison Association of Massachusetts

5I Cornhill

Boston, Massachusetts

Henry J. Mascarello, Executive Secretary

Massachusetts Society for Aiding Discharged Prisoners

40 Pemberton Square

Boston, Massachusetts

George E. Cornwall, General Agent

Society for the Friendless

I 2 North Second Street

Minneapolis, Minnesota

Rev. W. E. Paul

Society for the Friendless

518 Ridge Building

Kansas City, Missouri

Rev. James Parsons, National Superintendent 
The Missouri Welfare League

I 574 Arcade Building

St. Louis, Missouri

Miss Carol Bates, Executive Secretary,

Nebraska Council for Crime Prevention and Rehabilitation of Offenders

2.28 South Ioth Street

Lincoln, Nebraska

C. Philip Ross, Executive Secretary

Society for the Friendless

I 824 Garfield

Lincoln, Nebraska

Rev. Donald M. McIntosh

Society for the Friendless

Carson City, Nevada

Rev. J. C. Collins

Prisoners' Aid Society

Concord, New Hampshire

Edwin L. Page

Prisoners' Aid Society

Caldwell, New Jersey

Thomas W. Dennison, President

Society for the Friendless

Santa Fe, New Mexico

Rev. David Reiter

The Osborne Association

I 4 East 3oth Street

New York City

Austin H. MacCormick, Executive Director

The Prison Association of New York

I35 East I 5th Street

New York City

E. R. Cass, General Secretary 
The Salvation Army

I 20 West 14th Street

New York City

Col. William F. Palmer, Prison Secretary

Envoy J. Stanley Sheppard, Assistant Secretary

Volunteers of America

34 West 28th Street

New York City

Mrs. Maud Ballington Booth

Women's Prison Association

I ro Second Avenue

New York City

Miss E. Mebane Hunt, Executive Secretary

The Carolina Prison Association

Winston Salem, North Carolina

Rev. F. C. Mitchell, Superintendent

Society for the Friendless

Room 6, Stone Building

6I3 First Avenue

North Fargo, North Dakota

Rev. L. W. Bartholow, Superintendent

Oklahoma Lighthouse League

I $6 I / 2$ South Independence Ave.

Enid, Oklahoma

Society for the Friendless

6 I I Oil Exchange Building

Oklahoma City, Oklahoma

Rev. W. C. Wheeler

Oregon Prison Association

815 Dekum Building

Portland, Oregon

W. G. MacLaren, Superintendent

Pennsylvania Prison Society

3 I S. Juniper Street

Philadelphia, Pennsylvania

Albert G. Fraser, Executive Secretary 
Texas Prison Association

Capitol Station

Austin, Texas

The Texas Howard Association

Allen Building

Dallas, Texas

George W. Achilles, Superintendent

Society for the Friendless

$38 \mathrm{~J}$ Street

Salt Lake City, Utah

Rev. John Pearson

Washington Howard Association

5 I 3 Thompson Building

Seattle, Washington

G. S. Cole, Executive Secretary

Washington Prison Association

I038 Exchange Building

Seattle, Washington

Nelson Durham, Secretary

Wisconsin Society for the Friendless

I25 E. Wells Street

Milwaukee, $W$ isconsin

Mrs. Ruth Baker, Superintendent

Canadian Prisoners' Welfare Association

I 502 St. Catherine Street, W.

Montreal, Quebec, Canada

John Kidman, Executive Secretary

The John Howard Society of British Columbia 1006 Dominion Building

Hastings Street

West Vancouver, B. C., Canada

J. Dinnage Hobden, Executive Secretary

The Prisoners' Welfare Association

5 Chestnut Street

Halifax, Nova Scotia, Canada

Prof. C. H. Mercer, President 